March $2002 \quad$ N NREL/SR-500-28591

\title{
An Assessment of the Impacts of Green Mountain Power Corporation's Wind Power Facility on Breeding and Migrating Birds in Searsburg, Vermont
}

\section{July 1996-July 1998}

Prepared for the

Vermont Department of Public Service Montpelier, Vermont

By

Paul Kerlinger, Ph.D.

Curry \& Kerlinger, L.L.C.

Cape May Point, New Jersey

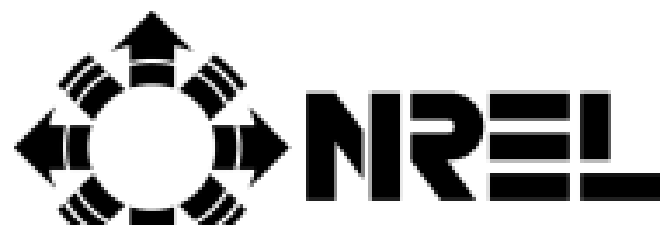

National Renewable Energy Laboratory

1617 Cole Boulevard

Golden, Colorado 80401-3393

NREL is a U.S. Department of Energy Laboratory

Operated by Midwest Research Institute $\bullet$ Battelle $\bullet$ Bechtel

Contract No. DE-AC36-99-G010337 
March 2002 • NREL/SR-500-28591

\section{An Assessment of the Impacts of Green Mountain Power Corporation's Wind Power Facility on Breeding and Migrating Birds in Searsburg, Vermont}

\section{July 1996-July 1998}

Prepared for the

Vermont Department of Public Service Montpelier, Vermont

By

Paul Kerlinger, Ph.D.

Curry \& Kerlinger, L.L.C.

Cape May Point, New Jersey

NREL Technical Monitor: Karin Sinclair

Prepared under Subcontract No. ZAT-6-15179

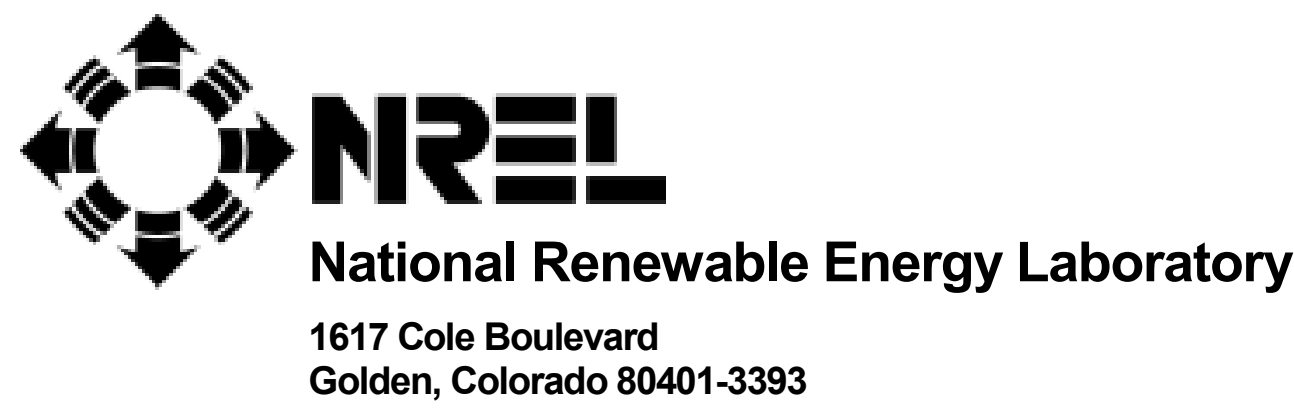

NREL is a U.S. Department of Energy Laboratory

Operated by Midwest Research Institute $\bullet$ Battelle $\bullet$ Bechtel

Contract No. DE-AC36-99-G010337 
This publication was reproduced from the best available copy Submitted by the subcontractor and received no editorial review at NREL

\section{NOTICE}

This report was prepared as an account of work sponsored by an agency of the United States government. Neither the United States government nor any agency thereof, nor any of their employees, makes any warranty, express or implied, or assumes any legal liability or responsibility for the accuracy, completeness, or usefulness of any information, apparatus, product, or process disclosed, or represents that its use would not infringe privately owned rights. Reference herein to any specific commercial product, process, or service by trade name, trademark, manufacturer, or otherwise does not necessarily constitute or imply its endorsement, recommendation, or favoring by the United States government or any agency thereof. The views and opinions of authors expressed herein do not necessarily state or reflect those of the United States government or any agency thereof.

Available electronically at http://www.osti.gov/bridge

Available for a processing fee to U.S. Department of Energy and its contractors, in paper, from:

U.S. Department of Energy

Office of Scientific and Technical Information

P.O. Box 62

Oak Ridge, TN 37831-0062

phone: 865.576 .8401

fax: 865.576 .5728

email: reports@adonis.osti.gov

Available for sale to the public, in paper, from:

U.S. Department of Commerce

National Technical Information Service

5285 Port Royal Road

Springfield, VA 22161

phone: 800.553 .6847

fax: 703.605.6900

email: orders@ntis.fedworld.gov

online ordering: http://www.ntis.gov/ordering.htm 


\section{Preface}

Funding for avian research projects by the Department of Energy/National Renewable Energy Laboratory has been ongoing since 1992. The process for reviewing avian reports submitted by their subcontractors is consistent with other programs at NREL. Part of this process involves external peer review by experts in fields related to the research under review. Although this document went through NREL's established external peer review process, several concerns raised by the reviewers were not addressed in this final report submitted by the subcontractor.

First, there is a generalization of the results. While the general conclusion of this report, that there will likely be limited avian impact at the wind farm in Searsburg, Vermont, may be correct, avian impacts identified by the author include fragmentation and species utilization shifts. The study, as designed, did not allow for extended post-construction monitoring to determine whether these impacts will change over time. Thus, it is unclear whether the wind project development has a long-term impact on any of the avian species historically using the wind resource area.

Second, while no carcasses were found during the study period, this does not necessarily mean that no birds were or will be killed as a result of wind turbine interactions at the Searsburg wind farm. While it is important to report the data as collected, it is also important to note constraints at the site, including low searcher efficiency rates and difficulty in finding carcasses because of the dense vegetation surrounding the turbines.

Third, the study lacked statistical analyses, including power analysis and sample size analysis. These analyses would have allowed the author to present an uncertainty analysis, and provide the reader with a basis for judging whether the results were statistically significant or were a result of chance.

In addition, reviewers were concerned about the discussion of bird abundance and its link to risk of death. Although abundance is one of the factors used to determine risk, the frequency of an individual bird performing a risky activity will increase its risk, even if the absolute number of individuals is low. An abundant species with high territorial behavior may not be at risk compared to a relatively uncommon species that crosses the turbine field regularly. 
Finally, the findings at the Searsburg, Vermont, the first wind farm development in a forested area in the United States, may be important for considerations of additional projects planned within the same region. The table below summarizes the almost $100 \mathrm{MWs}$ of wind development expected in the northeastern United States by the end of 2001.

\begin{tabular}{|l|c|}
\hline & Total expected wind (MWs) \\
\hline Maine & .1 \\
\hline Massachusetts & 1.0 \\
\hline New Hampshire & .1 \\
\hline New York & 48.3 \\
\hline Pennsylvania & 34.7 \\
\hline Vermont & 6.0 \\
\hline
\end{tabular}

Source: Global Energy Concepts/American Wind Energy Association, 9/30/01

Thus, NREL advises the reader to consider these review comments when making use of the results and conclusions reported herein.

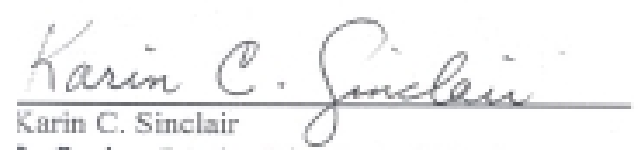

Sr. Project Leader II/Technical Monitor

National Wind Technology Center

National Renewable Energy Laboratory

1617 Cole Boulevard

Golden, Colorado 80401

E-mail: karin_sinclair@nrel.gov

Phone: (303) 384-6946

Fax: (303) 384-6901 


\section{Executive Summary}

A 6 megawatt, 11 turbine wind power development was constructed by Green Mountain Power Corporation in Searsburg, southern Vermont, in 1996. The turbines are Zond Z-40 turbines that stand 197 feet (about $60 \mathrm{~m}$ ) above the ground (to the rotor tip) on tubular towers. To determine whether birds were impacted, a series of modified BA (Before, After) studies was conducted before construction (1993-1996), during (1996), and after (1997) construction on the project site. The studies were designed to monitor changes in breeding bird community (species composition and abundance) on the site, examine the behavior and numbers of songbirds migrating at night over the site and hawks migrating over the site in daylight, and search for carcasses of birds that might have collided with the turbines. Findings of the study are as follows.

- A literature search was conducted to determine the extent and diversity of bird fatalities associated with tall structures (wind turbines, towers, stacks, and buildings) in the eastern United States and Canada. In addition, the literature search examined the impact of ceilometers and other types of lights on avian behavior and fatalities at tall structures. The survey revealed an abundance of tower kill studies with few being conducted recently. There were only two studies that reported carcass searches at wind power facilities in the eastern United States and Canada.

- Breeding bird surveys (point counts taken at 21 points) were conducted in 1994 before construction of the turbines, 1996 during construction, and 1997 after construction. Although no major changes in species composition were found, the numbers of several interior forest breeding birds were lower after construction than before construction and several edge species were more numerous after construction. It is possible that the songs of some of these species could not be heard because of turbine noise during some surveys. Such effects may be the result of forest fragmentation. Further study could determine if interior forest species recover as roadsides and areas around turbines are reforested and to determine if at the same time edge species decline.

- Searches for nesting diurnal raptors, particularly Northern Goshawk, conducted in spring of 1994 revealed no raptors nesting on or adjacent to the turbine site. No evidence of raptors nesting on the site was found during breeding bird surveys in 1996 and 1997, although two sightings of Sharp-shinned Hawks within $4 \mathrm{~km}$ of the site suggest that this species nests nearby.

- Nocturnal migration of songbirds through the wind power facility during spring 1994 and 1997 and autumn 1996 and 1997 suggested that the site is not a predominant migratory pathway. The numbers of birds flying over the site were the same as, or less than, the numbers reported from other inland locations in New England and many fewer than reported from studies done farther south. Fewer migrants were counted after construction of the turbines, perhaps indicating avoidance of the immediate turbine area by migrants.

- Hawk migration counts taken in 1993, 1994, 1996, and 1997 revealed small numbers of these migrants. Numbers of hawks counted were lower or the same as most sites in New England 
and two orders of magnitude lower than the counts taken at such concentration locations as Cape May, New Jersey, Lighthouse Point, Connecticut, and Hawk Mountain, Pennsylvania. A small proportion of the hawks observed prior to construction flew near enough to the turbine area to be at risk. Fewer hawks were counted in the year after the turbines were constructed than in the years prior to construction, perhaps indicating avoidance behavior.

- Searches for dead birds were conducted adjacent to turbines during the period June through October. No carcasses were recovered. Scavenging was rare with some songbird carcasses (from road and window kills) remaining on the ground for two or more months. Two tests of observer efficiency revealed that the two observers found about $50 \%$ of songbird carcasses placed out at random.

Overall, results of the studies reported herein suggest that the Searsburg, Vermont wind power facility does not pose a major threat to avian populations that breed on the site or migrate through the site. However, fewer interior forest breeding songbirds were heard singing in the area immediately surrounding the turbines. This effect may be transitory in that these birds may habituate and recolonize as the sites are partially reforested. However, until this is demonstrated, this disturbance should be recognized as a potential impact of this type of development, especially in northeastern forests.

Paul Kerlinger, Ph.D.

Curry \& Kerlinger, L.L.C.

31 Jane St. 14D

New York, NY 10014

(212) 691-4910, fax 989-3323

email: pkerlinger@aol.com 


\section{Forward and Acknowledgments}

The following study is the result of five years of effort (1993-1997), including planning, the permitting process, field studies before and after construction of the wind power plant, analysis of several individual and multiple data sets, and reporting each step along the way. The goal of this report is to summarize these studies in light of existing literature on tower impacts, to determine whether a small wind power facility built in southern Vermont will have impacts on bird populations or on individual from highly sensitive species (endangered, threatened, or rare).

In this final report and in preliminary reports that preceded it, the work of several other investigators was used, primarily as a baseline for comparison with other sites and with studies conducted after construction of the wind turbines. Initial, exploratory work was conducted in 1993 and 1994 by Nancy Martin and Dave Capen and Dan Coker. Martin conducted hawk migration counts in autumn 1993 and 1994 which served as comparisons with other sites and with two additional autumns of hawk counts and behavioral studies at the Searsburg site during and after construction. Capen and Coker, of the University of Vermont, conducted searches for Northern Goshawks in 1994, along with a breeding bird survey on the Searsburg site in that same year.

The studies conducted in 1993 and 1994, in the earlier stages of permitting the Searsburg project were funded by Green Mountain Power Corporation. Studies conducted in 1995 by Kerlinger were also funded by Green Mountain Power Corporation. Those studies conducted in 1996 and 1997 by Kerlinger were funded by the STEP process of the National Renewable Energy Laboratory (U. S. Department of Energy), with assistance from Green Mountain Power Corporation, Vermont Department of Public Service, and Vermont Environmental Resource Associates (VERA). John Zimmerman and Martha Staskus of VERA and Dave Lamont of Vermont Department of Public Service were extremely helpful from an administrative perspective. Special thanks to John Zimmerman for his time and patience. 


\section{Table of Contents}

\section{Page Number}

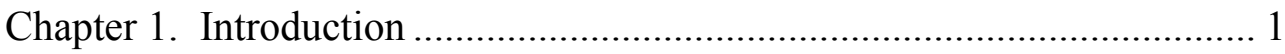

Chapter 2. A Literature Survey of Tower and Wind Turbine Impacts on Birds in the Eastern United States and the Influence of Ceilometers on Bird Flight ...................................................... 3

Chapter 3. Description of Searsburg, Vermont, Wind Power Facility........ 19

Chapter 4. Nesting Songbirds and Raptors ........................................... 20

Chapter 5. Nocturnal Migration of Songbirds: Spring and Autumn........... 37

Chapter 6. Hawk Migration .................................................................. 49

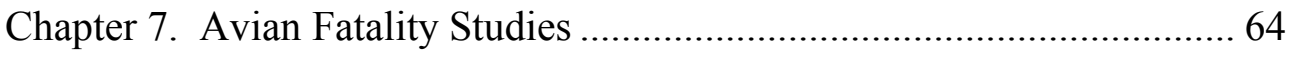

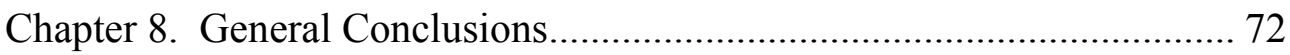

Chapter 9. Literature Cited................................................................ 74 


\section{Chapter 1. Introduction}

With the controversy over greenhouse gases, global warming, and air pollution regulations has come a renewed interest in developing "green" or nonpolluting power sources. Of all currently feasible "green" power technologies, wind power is emerging as one of the most cost effective for producing clean energy, in part because its price tends to be lower than power from other renewables. As a result, many new wind power developments in the United States and abroad are being planned and constructed. Wind power now supplies a growing number of communities, both large and small, with a varying percentage of their energy needs. Furthermore, there is an increased interest in renewables at the consumer and marketing levels, providing a greater demand for this emission free source of energy. Such demand is now predicted to continue its expansion in the coming decades, requiring a rapid response by this fledgling industry.

Although wind power traditionally has been perceived as being benign with respect to the environment, several complaints and reservations have been voiced from the environmental and regulatory communities. It is ironic that these complaints come from segments of society that years ago were strong proponents of wind power development. Three of the concerns of environmentalists and regulators are: (i) that turbines and infrastructure related to wind energy production are not compatible with some undeveloped areas; (ii) that wind turbines are deleterious to the viewshed in some areas; and (iii) that wind turbines kill birds. All are difficult problems. This report addresses the third issue, that of birds being killed by wind turbines.

A few studies have now been completed in the United States, Canada, and in Europe in which the impacts of turbines on birds have been studied (reviewed in Colson and Associates 1995, other references given in Chapter 2). However, the literature on bird-wind turbine interactions is scattered and obscure. Methods of study vary greatly, as do the results of those studies. In only a few cases have consistent efforts been made to look at changes in behavior and ecology of birds at wind turbine installations. A few studies have also sought to quantify the numbers of fatalities incurred by operating wind plants, but none have determined whether wind turbines have impacted populations of birds (Orloff and Flannery 1992, 1996, Howell and DiDonato 1991, Colson and Associates 1995, Anderson in press, Strickland in press, Winkelman 1995).

This project examines the question: Do wind power developments impact on birds, and, if so, what is the impact? This is the first commercial project to examine this question in the United States, east of the Mississippi River, mostly because the Searsburg wind power development is the first and only commercial wind power facility constructed in this area in several years. Two aspects of avian biology are examined: birds that breed on and adjacent to the Searsburg wind power facility and birds that migrate through the facility. The former includes raptors and songbirds that nest in the forests surrounding the site. The latter deal with songbirds that migrate over the facility at night and raptors that migrate over the facility in daytime. In addition, an effort was made to determine whether or not birds were killed by the turbines after they began operating. 
The research design used for much of the work reported herein is a modified BA (Before, After; Anderson et al. 1999 in prep.) design in that information on breeding birds and migrant was collected before and after construction of the turbines. The work focused primarily on songbirds and hawks nesting on and immediately adjacent to the site, songbird migrants flying over the site at night, and hawk migrants flying over the site in daytime. In addition, post-construction carcass searches were done to determine whether birds were being killed by the turbines. For breeding bird and migration studies, field data collected before and after construction will be used to compare behavior and ecology of the birds involved. Finally, a literature review of the impacts of towers of various sorts and ceilometers on birds and bird behavior was included to provide readers with an overview of this issue. 


\section{Chapter 2. A Literature Survey of Tower and Wind Turbine Impacts on Birds in the Northeastern United States and the Influence of Ceilometers on Bird Flight}

Prior to examining field data regarding the impacts of wind turbines on birds at the Searsburg, Vermont, facility, a literature review is presented to provide a background on how towers of various types, as well as the lights on those structures affect and impact birds. The first section of this chapter is a literature survey of the impact of towers, buildings, and other man-made structures, including wind turbines, on birds. The geographic scope of the survey is the northeastern United States and southeastern Canada. The second section of this document is a literature survey of the ceilometer technique as a method for studying night migrating songbirds. The survey examines the method, its biases, and its strengths as a tool for studying bird migration and examines how the method has been employed during the past four decades.

The avian and wildlife literature is replete with studies of the impacts of man-made structures on birds. One of the most recent reviews contained more than 500 references (Colson \& Associates 1995) and others have contained in the dozens to hundreds of references (Aldrich et al. 1966, Avery et al. 1980, Banks 1979, Jaroslow 1979, Weir 1976), mostly focusing on towers and high-tension wires in the United States and Canada, although many of the more recent references refer to impacts of wind turbines (Colson and Associates 1995) and windows (Klem 1989, 1991; Evans Ogden 1996). Other types of structures have been implicated in bird mortality including lighthouses, tall buildings, chimneys, airport ceilometers, and lighted buildings.

Of the structures that are known to kill birds via collision, windows seem to have the greatest impact, followed distantly (Banks 1979, Klem 1991) by lighted towers. Each year about 100 million birds are killed when they collide with windows (Banks 1979, Klem 1990). Perhaps 1.3 (some estimates as high as 2-4) million are killed by buildings, towers, and chimneys (Banks 1979, Klem 1990, 1991). It is believed that the reflection of either sky or vegetation is what "lures" birds into windows. Hereafter this review does not examine window collisions.

Windpower turbines, because they are so new, are the focus of intense research here in the United States, as well as overseas. The reason for the concern stems from a series of findings at wind turbine facilities (sometimes called wind farms) that demonstrate that birds do, at times, collide with wind turbines. Specifically, Golden Eagles, Red-tailed Hawks, and American Kestrels were found below turbines in the Altamont Pass area where thousands of wind turbines are now situated. The numbers of birds killed in the Altamont Pass area was detailed in a two-year study by Orloff and Flannery (1992) in which 183 birds were found dead, of which 119 (65\%) were raptors. The Altamont Pass area now has 5,400 operating wind turbines and "may be the worst-case scenario for bird interactions" with wind turbines (Colson and Associates 1995). Several hypotheses have been proposed, but many researchers agree that the availability of prey which supports a large population of raptors (Orloff and Flannery 1992) is important. Other multi-year studies in California at the Tehachapi and San Gorgonio wind energy areas revealed few raptor fatalities. Thus, there is a large amount of variation in the mortality reported among wind turbine facilities. 
The geographic and ecological scope of studies of the impact of man-made structures on birds has been limited, with only a few studies from the northeastern United States and Canadian maritime provinces. There are many studies of tower, chimney, and ceilometer bird kills from the Midwest (Table 2.1, area from Missouri to Minnesota eastward to Pennsylvania, West Virginia, Tennessee, Kentucky) and the southeastern United States (Table 2.1). Fewer studies are available for the northeastern United States and southeastern Canada (Table 2.1). A state by state review shows that very few or no studies of tower, chimney, or ceilometer kills conducted in Vermont. The reason for this geographic disparity is unknown, but there are two possible explanations.

General reviews of the problem usually summarize or list the numbers of birds killed at various tower or other structures or provide annotated lists of studies that have been conducted (Avery et al. 1980, Banks 1979, California Energy Commission 1995, Newman 1958, Evans Ogden 1996, Weir 1976). Few reviews of the wind turbine literature are available from North America (Colson and Associates 1995, Orloff and Flannery 1996) or Europe (Benner et al. 1993, Winkelman 1994, 1995). The most recent review of the wind turbine - bird interaction problem provides what may be the most detailed analysis of the problem yet undertaken (Orloff and Flannery 1996).

The numbers of birds killed ranges from only a few individuals (25 birds of 16 species, Able 1966) to more than 50,000 in about seven days (Johnston 1955). The latter was mortality caused by a large ceilometer. Kills of $>1,000$ individuals in a single night (Able 1973, and many other references, see Tables 2.1 and 2.2) are not unusual, although they occur on a limited number of nights as demonstrated in several season long studies. For example, Strand (1962) documented 2,000+ birds of 66 species killed in one season, of which, 525 were killed in one night. There are a few instances where 10,000 to more than 30,000 birds were documented as tower kills for an entire season. For example, Eaton (1967) estimated that more than 10,000 birds per year were killed by a half dozen towers in western New York. More than 57 species of night migrating birds were found dead. The numbers are more often in the hundreds for a season or a night (Whelan 1976, Zimmerman 1975).

Fatalities are more often associated with autumn migration than spring migration. In some studies autumn mortality was more than 10 times the mortality found in spring. For example, at a lighted chimney in Ontario, Weir (1974) found 1,188 dead birds in autumn and only 92 the preceding spring. Stoddard and Norris (1967), working over an 11 year period, also found many more fatalities around Florida TV towers during autumn than in spring. However, because there are few rigorous studies involving both spring and autumn over several years, the difference between autumn and spring migration fatalities should be considered as not firmly documented.

\section{Factors Affecting Tower Kills}

There are at least six factors that need to be considered as contributing to the number of birds killed by towers. These factors include height, whether the tower or other structure is lighted, weather/visibility, guy wires, geographic location, and topography. The last two factors have yet to be studied. They are included in this review because the author felt the need to be complete and identify the need for future studies. Unfortunately, few studies have been conducted in such a way as to enable us to say definitively that one factor is more important than another. It is likely that there is significant interaction among the factors that together promote kills. Those factors are reviewed below. Reviews 
and studies of the various factors can be found in Aldrich et al. (1966), Avery et al. (1977), Brewer and Ellis (1958), Cochran and Graber (1958), Elkins (1988), Evans Ogden (1996), Jaroslow (1979), Seets and Bohlen (1977), and Stoddard and Norris (1967).

Height. Although no thorough investigation and analysis of the relationship between height and amount of bird mortality at towers has been undertaken, this review (see Table 2.1 and 2.2) reveals that taller towers may be more dangerous to birds than shorter towers. The largest bird kills are reported from towers that are fairly tall. Some exceed two thousand feet in height above the ground. TV towers in excess of 900 feet (about $277 \mathrm{~m}$ ) tall frequently are responsible for kills greater than 1,000 birds in a single night.

One series of studies in Ontario demonstrated just how deadly towers could be (Evans Ogden 1996). Most of the TV towers involved exceeded 600 feet $(185 \mathrm{~m})$ in height, with some extending above 1,000 feet (308 m) Hoskin 1975). In addition, all of the towers and chimneys were illuminated by red lights or white strobes. Studies done at towers $>1,000$ feet $(308 \mathrm{~m})$ tall in Barrie, Ontario, revealed kills for August and September alone to be nearly 5,000 songbirds. Warblers were most numerous, although grosbeaks were also present among the dead.

Even small towers and buildings kill birds at times. Towers ranging between 200 and 400 feet 61-123 $\mathrm{m})$ killed dozens of birds in the Bahamas during October migration, including Gray-cheeked Thrushes and Blackpoll Warblers (Kale et al. 1969). Three towers with heights of $250(77 \mathrm{~m}), 400(123 \mathrm{~m})$, and 408 feet $(125 \mathrm{~m})$ in Marysville, MO, were studied during autumn 1972 to determine whether they were dangerous to birds. Although birds were killed, there were no large, single-night kills with only 71 birds of 33 species found. Most seemed to have collided with guy wires (Ball 1973).

Small towers that are situated on ridges and mountain tops may have greater impact than short towers that are not located in such topographic situations. Studies along the ridges of West Virginia (Hall $1966,1968,1976,1977)$ show that fire towers, microwave relay towers, and other types of towers, usually less than 200-400 feet (61-125 m) in height, can kill hundreds of birds in a year. Such events, however, seem unusual because there are few reports of such kills. An examination of the relationship of tower height and the topography surrounding the tower site to bird fatalities is indicated.

Guy wires. In addition to the main portion of tall communications towers, dozens of guy wires are often used for stability and to prevent the tower from falling over. Some of these towers have dozens of guy wires that extend more than 700-1,000 feet (215-308 $\mathrm{m}$ ) above ground, as is the case with a TV tower in Elmira, NY (Welles 1978). These wires may account for more casualties than the tower itself. At the Elmira tower upwards of 4,000 birds were killed in a five day period in September of 1977. Guy wires were also noted as responsible for killing migrants by Ball (1973) at some towers in Missouri. The Avery et al. (1977) review and analysis was similar.

Lights. The role of tower lights in mortality events has been investigated by several researchers. A review by Evans Ogden (1996) makes this point painfully clear. At a 984 foot $(303 \mathrm{~m})$ tower lighted with red lights in Illinois, Cochran and Graber (1958) reported that migrants concentrated in the vicinity as a result of those lights. They based their conclusion on the change in numbers of flight calls heard near the structure by counting calls at times when the tower was lighted with times when it was 
not lighted. There were fewer calls when the red warning lights were out. Apparently, there were fewer mortalities, so turning out lights may reduce the numbers of birds killed (Maher et al. 1983).

Weather/Visibility. For many of the studies of bird mortality around towers, weather has been reported as a contributing factor (Seets and Bohlen 1977, Avery et al. 1977, Elkins 1988). One of the clearest examples of bird mortality at towers associated with poor visibility is a study by Strand (1962), who found that 25\% of all kills at a TV tower in Minnesota occurred on one night. That night was overcast. Benning (1978) reported that rain on several nights at an Elmira, New York, tower resulted in nearly 4,000 dead songbird migrants. Although some birds are killed on clear nights (Avery et al. 1977), the numbers seem to be much greater on either cloudy nights with a low ceiling, or on nights with fog or precipitation.

Seets and Bohlen (1977) conducted an intensive study at seven towers ranging from 600 to 1,500 feet (185-462 m) in height in central Illinois. They concluded that most birds were impacted on nights with low cloud ceilings (less than 1,600 feet [492 m]). They also found that there was no relationship between bird mortality and tower height, topography, or location of the towers. The reason for the lack of correlation between these variables is that all towers were greater than 600 feet $(185 \mathrm{~m})$ in height and that all were within a small geographic area. These conclusions cannot be used for comparing towers at very different geographical or topographic sites (i.e., Atlantic coast vs. Kansas corn fields).

The reason lights and weather seem to be related in their ability to influence tower kills has been discussed by several researchers. Jaroslow (1979) stated that on overcast nights birds are deprived of visual orientation cues and that lighted towers confuse them. Nights with low clouds and precipitation diffuse lights and confuse birds even more. When they encounter the diffuse lights, they fly in circles and eventually collide with a tower or a guy wire. Elkins (1988), Avery et al. (1977), Cochran and Graber (1958), Herbert (1970), and Seets and Bohlen (1977) give similar or partial explanations.

Summary and Conclusion Regarding The Above Factors

1. Tall towers kill more birds than short towers

2. Short towers do kill some birds, although towers less than 300 feet (92 m) in height are rarely implicated in mortality.

3. Lighted towers kill more birds than unlighted towers.

4. Height in conjunction with lights kills more birds than either factor alone.

5. Guy wires kill as many or more birds than the actual towers, especially at large towers were there are dozens of guy wires.

6. Poor visibility caused by fog, precipitation, or low cloud cover increases tower kills.

7. Poor visibility in conjunction with tall, lighted towers kills more birds than any other combination of factors.

8. This list of factors is tentative and poorly understood, but can serve as a working hypothesis for field studies.

\section{Studies of Bird Mortality at Wind Turbine Facilities in the Northeastern United States}

Very few studies have been conducted in the northeastern United States or eastern Canada to determine the extent to which wind turbines kill birds. The reason for this is that there are few wind 
turbines now operating in this geographic area. Furthermore, those operating plants are small, consisting of only a few towers, nothing like the facilities with hundreds and even thousands of towers, like those in California and other parts of the western United States. It will be many years before analyses such as those contained in the Orloff and Flannery (1996) report will be available for the northeastern United States because there are few turbines to study. Such analyses should be the longterm goal of researchers and utilities because they will elucidate the most frequently asked questions and provide answers to management problems and concerns.

A very brief summary of bird mortality resulting from wind turbines in other parts of the world follows. Mortality at western facilities has been studied extensively, especially at the Altamont Pass area, near San Francisco, California (Orloff and Flannery 1996). Mortality reported for the Altamont Pass Wind Resource Area (AWRA) had been the concern of environmentalists and, therefore, the focus of several studies. Fatalities for the period 1989-1991 amounted to 182 dead birds, $65 \%$ of which were raptors. There were also a very few ravens. Mortality was found to be higher at the last turbine (end turbine) of a string of several turbines, at turbines with lattice towers (as opposed to tubular towers), at turbines on higher elevations, and at turbines close to canyons. The total number of deaths extrapolated to the 7,500 turbines in the AWRA for each of the two years of study ranged between 164 to 403 raptors. This amounts to a rate of 0.02 to 0.05 raptor deaths per turbine per year, although the potential for imprecision of these rates was considered to be large. Some other studies of raptor mortality at the AWRA have demonstrated similar mortality rates (Howell and DiDonato 1991, Howell and Noone 1992, Howell et al. 1991, Orloff and Flannery 1992, 1996).

Kerlinger and Curry (1997) analyzed 9 years of Golden Eagle and Red-tailed Hawk kills at Kenetech model KCS-56 turbines in the AWRA. Relying on the Wildlife Response and Reporting System (WRRS), established by Kenetech as a database to report and database kills, they showed a strong nonrandom pattern of fatalities of these species. Only 13\% of all 3400 Kenetech turbines ever killed one of these birds and a few individual turbines killed two or three. Curry and Kerlinger demonstrated that topography explains fatalities better than any other factor at an existing wind plant. About 60$70 \%$ of all kills for these species were associated with end of row and second from end of row turbines, as well as turbines situated on steep hillsides or in notches/valleys in ridges. Interestingly, end of row turbines situated on steep hillsides were very dangerous, but end of row turbines that were situated on a ridge top or at the top of a hill had few fatalities. They concluded that birds attempting to fly around the end of hills or through notches in ridges may not have been able to see the turbine until it was too late. Thus, most kills seemed to be associated with flight. They could not, however, rule out the possibility that perching of birds on lattice towers on site did not indirectly or directly contribute to fatalities. If Kerlinger and Curry are correct about topography being the most important factor, better planning of wind power sites will greatly reduce risk for some species.

European wind farms tend to be small compared to large California wind farms, although bird mortality may be greater (deaths per turbine per year). Windfarms in Europe, until very recently, rarely consisted of more than 25 turbines and were often near the North Sea coast. The newer and recently proposed wind turbine facilities will involve more turbines. The European studies examined mortality, along with disturbance and loss of habitat (Crockford 1992, Benner et al. 1993, Winkelman 1994, 1995). Some wind turbine facilities have been shown to influence the behavior and ecology of birds. Studies done in Europe are difficult to compare with the studies done in California because 
many of the European sites are coastal as opposed to being inland as in Europe and involve far fewer turbines than in California. As more studies are conducted in the eastern United States and eastern Canada, comparisons with the European studies will be of heuristic value because of the similarities between size and topography at wind power facilities in these areas.

Although little is known about avian mortality at wind power facilities in the northeastern United States, a review of the topic was published in 1994 (Jacobs 1994). The conclusions of this review were that mortality projections based on studies from the Altamont WRA and other WRAs in California are not likely to be accurate or good predictors of mortality at wind turbine sites in the northeastern United States. In addition to these conclusions, the author made "direct observations of the longest operating northeast wind farm, in Princeton, Massachusetts." The methods used for this study were interviews of owners of two small wind energy facilities (listed in Table 2.3) who have searched, mostly in a nonscientific or systematic manner, for dead migrants below their turbines.

The Jacobs (1994) review makes several important statements. It focuses on how limited wind turbine facilities are in the northeastern United States and how small the existing facilities are. Whereas studies in California include fatality estimates for upwards of 7,000 individual turbines in a single wind resource area, the largest number of wind turbines at a single facility in the northeast was 9. If all turbines in the five facilities he reviewed were combined the total would only be 22 turbines.

Jacobs attempted to replicate dead bird searches that are standard in California Energy Commission studies (1995) at a wind farm in central Massachusetts (Princeton, MA, see Table 2.3 for details on turbines). Despite difficulties associated with steep hillsides and thick brush, searches were conducted, but no deaths were detected. Turbine operators, mechanics, and maintenance workers were queried about possible fatalities, but none was noted. This lack of fatalities at a wind farm adjacent to the Wachusett Mountain hawk watch, one of the better hawk watching sites in the northeastern United States, is very interesting. Annual counts of 5,000 or more migrating hawks are known for autumn migration at this site.

The Jacobs review gives some interesting perspective by comparing eastern and western wind turbine settings. Ecologically, most eastern facilities are situated on high hills or ridge tops that are forested, whereas those in the west are on rolling hills, passes, or in valleys, usually devoid of trees. Two of the eastern facilities are located on islands a short distance off the coast of Massachusetts and are not forested. Jacobs recommends that clearings under wind turbine be allowed to grow in as brush or low forest, primarily to discourage raptors from foraging there. These are the same recommendations made by this author to Green Mountain Power Corporation for the management of the Searsburg wind facility, which is now being constructed.

Thus, those bird mortality studies that have been done in the eastern United States consist primarily of studies of the potential for mortality at proposed wind turbine sites (as in this report) or studies conducted at meteorological towers situated at proposed wind turbine sites. I was able to locate only one study of avian mortality at an active wind turbine facility in this area. Cooper et al. (1995) conducted radar and direct visual studies of migrating songbirds, waterfowl, hawks, and other birds to conclude that impacts of wind turbines on birds migrating over the Tug Hill plateau, near Carthage and Lowville, New York, and at Cape Vincent, New York, on Lake Ontario, would be minimal. These researchers did ground searches below two, $42 \mathrm{~m}$ (138 foot) turbines and $30 \mathrm{~m}$ (100 foot) 
meteorological towers and made both visual and radar observations of migrants during both spring and autumn migration. The presence of a sizable migration of hawks and songbirds nearby along Lake Ontario (Derby Hill Hawk Watch) is noteworthy.

Cooper et al. (1995) also evaluated the magnitude of the migration of hawks, songbirds, waterfowl, and other birds through the area with both direct visual observations and radar. The purpose of these observations was to evaluate the potential for impacts in the event that more turbines were erected. They did not see collisions, nor did they find dead birds. Also, the migrations through the area were significantly dispersed and high enough so that they would not be impacted by turbines. Both of these findings seem to justify their conclusions.

At a site in northwestern Maine, near Stratton, where a large wind turbine facility was proposed, and is currently permitted via the Land Use Regulatory Commission for the unincorporated townships of northern Maine, several studies of night migration by songbirds and daytime migrating hawks were conducted in 1994 (Northrop, Devine, and Tarbell 1995a,b,c,d) and 1993. No dead birds were found near the meteorological tower (and four guy wires) during 20 searches in spring 1994 or during 17 searches in autumn 1994.

To examine potential impacts of wind turbines on songbird migrants at the Maine site a portable marine surveillance radar was used to examine the geographic pattern of bird migration and numbers of songbird migrants aloft at night in spring and autumn of 1994. In addition, a ceilometer was used only a few meters from the meteorological tower to determine the number and direction of nocturnally migrating birds. Finally, because many songbirds continue their nocturnal flights into the next morning, the Northrop, Devine, and Tarbell research team made observations to determine the magnitude, altitude, and direction of migrants that undertook morning flight. They detected no large aggregations of migrating songbirds, and concluded the turbines would have minimal impact on bird populations. Raptor migration studies done at the Maine site documented that few raptors migrate through the site as compared to along the Maine coast and farther south at known hawk migration concentration sites. As with the songbird migrants, the conclusion was that impacts of wind turbines on bird populations would be small.

Studies using ceilometer and direct visual observations at Searsburg, Vermont (Kerlinger 1995a), were conducted to evaluate the potential for impacts on migrating songbirds, migrating hawks, and breeding birds (songbirds and raptors). These studies are reported in Chapter 5 of this report. In short, two seasons of autumn hawk watches, a breeding raptor survey, a breeding songbird survey, and a ceilometer study of nocturally migrating birds were conducted. In 1993 and 1994 migrating hawks were studied at the site of a proposed, 11 turbine facility near Searsburg, Vermont. The studies consisted of counts of hawks migrating through the area After the studies, Kerlinger was retained to evaluate the data in those reports. The data were then compared to known raptor migration hot spots and the counts were found to be a small fraction of what is seen at hawk migration count stations along the Massachusetts coast, Maine coast, farther south, and at some ridge locations to the south. The breeding hawk survey failed to show significant concentrations of breeding hawks and no threatened or endangered species. The breeding songbird studies revealed only one or two individuals of the Bicknell's Thrush, a "new" species, formerly a subspecies of the Gray-cheeked Thrush. This species is 
a species of concern because of its limited breeding range at the tops of tall mountains in the northeastern United States and Canada. Finally, the ceilometer study of night migrating birds conducted during spring of 1995 showed very few birds migrate at low altitudes over the hilltops on which the turbines are being built. All of these studies led researchers to the conclusion that impact would probably be infrequent,with no population effects.

A study conducted on Nantucket Island, Massachusetts, in October 1995 (Kerlinger 1995b) for the Conservation Law Foundation examined the potential impact of a proposed wind turbine facility on migrating and breeding birds. The study, contracted by the Conservation Law Foundation, concluded that four wind turbines would have some impact, but it was not likely to involve large numbers of birds. Impacts were predicted for gulls, especially, because the turbines were to be situated around a landfill frequented by thousands of gulls of several species. The study also recommended that more extensive research be conducted, especially during migration season.

In summary, no bird mortality has been demonstrated at existing or proposed wind turbine facilities in the northeastern United States. The reason for this is that very few studies have been conducted and those that have been conducted at turbine sites with only a very few turbines or at sites where there are only one or a very few meteorological towers. There are at least three explanations for these early findings: birds are not impacted, so few birds are impacted that mortality is difficult to assess, or mortality does occur but the threshold for detecting it has not yet been reached. The paucity of information on this topic and the paucity of wind turbine facilities in the northeastern United States make it impossible to speculate on the actual impact of wind turbines on bird mortality or bird populations in the northeastern United States.

\section{The Use of Ceilometers to Study Nocturnal Migration of Songbirds}

Ceilometers have been used to study the night migration of songbirds since the 1960's (Gauthreaux 1969). A ceilometer is simply a very narrow, "pencil-beam," light. The ceilometer beam is roughly one-half of one degree and lights up a very limited amount of the night sky. The ceilometers used to study bird migration are usually no bigger than an automobile headlight and are powered by 6 or 12 volt battery or $120 \mathrm{v}$ line power. Ceilometers in the range of $100 \mathrm{~W}$ and 400,000 candle power are standard for studying bird migration. These ceilometers can "see" to more than 2,000 feet and birds can be detected throughout much of this range, although small birds are more visible below 1,500 feet. In fact, it is often possible to discern the species group of bird (e.g., thrush vs. kinglet, thrush vs warbler) as it passes through the beam. The use of ceilometers has been described and reviewed by Gauthreaux (1969, 1985), Able and Gauthreaux (1975), and Kerlinger (1995c).

Ceilometers provide the easiest and most cost effective means of sampling the amount of low altitude migration passing through a given area, for determining the basic species composition (songbirds vs. shorebirds vs waterfowl), and for determining the direction of migration. Studies involving portable ceilometers have been used in various settings to study bird migration both for basic and applied research. To study bird migration using a ceilometer, the ceilometer is placed so that it shines in a perfectly vertical direction into the night sky. An observer looks up the beam by lying with their head to the north and feet to the south. Optics for this type of work include either a 20X spotting scope 
mounted on a tripod or a 20X pair of binoculars mounted on a tripod. The scope or binoculars should also be aligned vertically and be focused at near infinity. The optics should encompass the main portion of the ceilometer beam. The scope/binoculars and ceilometer should be separated by about 50 feet so that insects that fly in the lowest portion of the beam are not visible.

Observations are made as birds are seen passing through the beam. Clock face coordinates are recorded to determine migratory direction. For example, a bird passing from 12 o'clock to 6 o'clock is going toward 180 degrees or due south. A bird passing from 6 to 12 is traveling due north. A bird passing from 3 to 9 is traveling due east. Careful attention must be paid to starting and stopping times because the traffic rate, an absolute and relative measure of the numbers of birds aloft, is per unit of time watched. Sampling periods can range from a few minutes to more than one hour in an evening.

Field tests of the methods have been accomplished in many locations and topographic situations. Bingman et al. (1982) used the method to study the behavior of songbird migrants flying in the Hudson Valley near Albany, New York, and a nearby mountain range. More recently, ceilometers have been used in conjunction with radar to measure the direction, quantity, and altitude of migration (Gauthreaux 1985). In the latter case, the ceilometer is observed via a video camera with a vertical radar measuring the altitude of birds passing through the ceilometer and radar beams simultaneously. This system was used by McCrary et al. (1983) to evaluate the numbers of birds aloft, direction, and height of songbird migration in the San Gorgonio wind resource area prior to its construction. Ceilometer observations were combined with marine surveillance radar by Northrop, Devine, and Tarbell (1995a, 1995b, 1995d) to assess the potential for bird fatality at a proposed windpower site in northwestern Maine. Finally, ceilometer observations were used by Kerlinger (1995a) to assess migration passage rates in southern Vermont at a site proposed for wind power development (the Searsburg, Vermont, wind power station).

Ceilometers have also been used to observe the takeoff of migrants. Hebrard (1971) working in small oak forests along the Gulf of Mexico in Louisiana aligned his ceilometer in a nearly horizontal fashion, tilted just above the horizon. By doing so, he was able to see migrants just after they had taken off from these forests and determine the daily timing of migration initiation. Such ingenious uses of ceilometer suggest that still other uses of this technique may be discovered.

There are several biases inherent when using ceilometers to study migrating birds. The first, and perhaps most important, is that ceilometers cannot be used on all nights. The presence of a bright moonlit sky makes the ceilometer beam less effective (personal observations). Therefore, ceilometers work best on nights when the moon is not full or close to being full and before the moon rises. A second bias involves weather conditions that either block the ceilometer from illuminating the night sky or diffuses the ceilometer beam, making it ineffective. Low clouds can do this as can fog or light precipitation.

Two other biases must be noted. Because the ceilometer beam is a cone, being narrow at the ground and much wider at higher altitudes, the ceilometer does not sample birds uniformly through the vertical airspace. At very low altitudes (< about 40 feet $[12 \mathrm{~m}]$ the beam is narrow so detecting birds is difficult). Also, at high altitudes, birds flying through the edge of the beam are not easily detected because the light at the edge of the beam is weaker. Thus, the beam is not as effective at higher 
altitudes or very low altitudes. In addition, birds flying at very high altitudes ( $>2,000$ feet [615 m]) will not be detected. Ceilometers should be used during the first two hours of migration during an evening and should be used at comparable times on all evenings during a study. By standardizing methods, ceilometers provide the researcher with a reliable quantitative measure of the traffic rate of migrants aloft and their direction. This rate can be a valuable means of evaluating potential risk at a site and for comparing risk at a number of sites.

A study by Able and Gauthreaux (1975) demonstrated that ceilometers are accurate indicators of migrants aloft within certain limits. By comparing the traffic rates of migrants aloft as measured with radar (Gauthreaux 1970, 1971, 1973) with simultaneous ceilometer measurements, these researchers found a linear relationship between the two estimates. The total variation accounted for in the regression was $71 \%$, indicating an exceedingly high relationship between radar and ceilometer measurements. Though there was variability around the regression line (radar on ceilometer), it was small compared to the orders of magnitude that migration volume varies among nights (Able 1973).

Ceilometers, on rare occasions, disorient birds. At such times, migrants can be seen "hovering" or turning in the beam, usually for less than 2 seconds (personal observation, Able and Gauthreaux 1975). This occurs in fewer than one in every two hundred to five hundred birds (personal observations) and usually happens when low clouds or high relative humidity (fog or light rain) diffuse the ceilometer beam (Able and Gauthreaux 1975). At these times, ceilometer beams have been known to disorient birds in the same way that other types of lights (on towers) and large scale airport ceilometers and floodlights can disorient birds.

More powerful ceilometers are often associated with disorienting songbirds that are migrating through an area (Aronoff 1949, Tanner 1954). These ceilometers, used around airports to guide planes, are larger and more powerful than the ceilometers used to study birds. Their beams are also wider and penetrate to many thousands of feet. These ceilometers also often move back and forth through the sky like a metronome. Airport ceilometers, because they are so bright and powerful, tend to diffuse large amounts of light, especially when dust or water vapor is present in the night air or when clouds are at relatively low altitudes. For this reason, airport ceilometers have been implicated in the confusion of night migrating birds and in death. Herbert (1970) has proposed a theory to explain why direct (ceilometers), and refracted and reflected (tower lights) cause a loss of true visual cues among migrants, confusing them prior to collisions. Elkins (1988) proposed a similar hypothesis, explaining that deaths occur most often and in greatest numbers when refraction and reflection of light from water droplets increase the amount of illumination in an area. That is, the light is dispersed and the source is obscure. This acts to disorient the birds. He also suggests that diseased and malformed birds are more susceptible to the influence of lights.

Large scale ceilometer associated mortality events involving hundreds, or even thousands, of individuals on a single night have been reported from North and South Carolina (Anonymous 1954), Tennessee (Aronoff 1949, Tanner 1954), Minnesota (Green 1963, 1964), Massachusetts (Baird 1962), The numbers of birds involved ranged from 200 to more than 50,000, showing that ceilometers can kill large numbers of birds. Perhaps the largest incident occurred at Warner Robins Air Force Base, Macon, Georgia, where 50,000 birds died during three October nights (Johnston 1955). At all of these sites, airport ceilometers have been implicated. In many of the cases listed above, the weather was 
overcast (Tanner 1954), foggy, or rain was present. It seems that on clear nights, ceilometer lights are not reflected and refracted so that birds are not disoriented, at least in noticeable numbers, and there is little or no mortality.

A similar situation to ceilometers causing mortality is the presence of floodlights illuminating tall industrial chimneys. Several 650 foot $(200 \mathrm{~m})$ chimneys in Lennox, Ontario, illuminated by floodlights, killed thousands of birds. Even when the lights were dimmed, collisions continued, albeit in smaller numbers (Weir 1974, 1977). In Springfield, Massachusetts, a "searchlight" was reported to have been responsible for the deaths of more than 200 warblers and flycatchers during their autumn migration (Baird et al. 1959).

Lighthouses also are responsible for ceilometer-like bird mortality. One incident in the Bay of Fundy (Bagg and Emery 1964) involved more than 100 individuals, most of them being warblers.

Lighthouses, perhaps because they do not extend above 200-300 feet (62-92 $\mathrm{m}$ ) above the ground, do not seem to inflict as many avian casualties as do TV and radio towers, which are much taller.

\section{Conclusions}

\section{Interpretive and Analytical Problems}

Interpreting the literature on actual impact of towers, wind turbines, and other structures on migrating and other birds is extremely difficult. Height of the structure was often omitted and information on whether the structure was lighted, the type of lights on the structure, and, or weather at the time of strikes was not provided. For the purpose of this review, I assumed that all TV towers were lighted. Because many authors made reference to overcast, rain, fog, or similar conditions being associated with tower kills, it is likely that these factors play a strong role. Before probabilistic statements regarding the amount of impact on birds can be made, better data will have to be available and a rigorous statistical analysis undertaken.

\section{Wind Turbines and Bird Impacts - Comparisons and Conclusions}

There is no doubt that tall, lighted towers kill many thousands of migrating birds each year. Although they also kill non-migrating birds, the number seems to be much lower. To back up this statement is the fact that there are virtually no references in the literature to these types of kills, with the exception of collisions with high tension wires (Gauthreaux 1985).

Comparing the numbers of birds killed by towers with those killed by wind turbines is not easy, because the studies that have been done have been done in different places and using different methods. Suffice it to say that no studies of wind turbines have revealed anywhere close to the numbers of fatalities or collisions as reported for TV towers, tall chimneys (in excess of $150 \mathrm{~m}$ ), or even ceilometers and tall buildings. The reason for this difference may be related to the height of bird migration as compared to the height of TV towers, chimneys, and other tall structures with wind turbines. For much of their migration, whether it be at night or in the daytime, birds migrate at altitudes greater than 200 feet (Kerlinger 1989, Kerlinger 1995c, Kerlinger and Moore 1989). In fact, most nocturnal migration by songbirds occurs between 300 and 2,000 feet (Able 1970, Kerlinger 
1995c, Kerlinger and Moore 1989). Waterfowl and shorebirds actually migrate higher during their nocturnal and diurnal flights (Kerlinger and Moore 1989). Wind turbines extend into the lowest strata of bird migration. In addition, turbines less than 200 feet in height are not lighted so are unlikely to disorient or attract migrants. Hawks sometimes migrate at very low altitudes ( $<100$ feet), but these birds migrate in daylight when they can see obstacles and take evasive action. Because almost no hawk fatalities have been reported from communications towers of any height, it does not appear that towers are a risk to these birds except in rare instances. The Altamont WRA of California is one such instance.

In the northeastern United States, in part because there are so few wind turbines now operating in this region, there has yet to be a single confirmed fatality. Other reasons for the paucity of wind turbine induced bird mortality is that wind turbines are less than 200 feet $(62 \mathrm{~m})$ in height and they are not lighted as compared with TV towers, which are usually taller than 600 feet $(186 \mathrm{~m})$ and lighted with either blinking red or strobe lights. Because lights and heights in excess of 600 feet $(186 \mathrm{~m})$ seem to be the most important factors correlated with avian deaths at towers, turbines that are less than 200 feet $(62 \mathrm{~m})$ and not lighted will kill far fewer birds.

Another caveat to this literature survey is necessary. Very few biologists have attempted to determine or even speculate on whether towers have impacts on populations of birds. That is, there are no quantitative analyses that permit us to evaluate the real danger of towers to migrating birds. Although millions of birds are killed each year by towers, these losses may have an impact on the populations or conservation status of species. Mayfield (1967) stated that tower losses may account for one million deaths each year but that number accounted for less than $1 \%$ of the annual mortality of birds (a number not too different from those reported by Banks 1979 and Klem 1991). This suggests that tower kills do not impact large scale populations of species with wide geographic ranges. Certainly, there is need for more investigation.

In addition, it was interesting that during the course of this literature search, very few references on tower kills were available for the last decade. One author (Baird 1962) speculated that tower kills are first noticed shortly after a tower is erected and that within a few years the numbers killed are not as great and that it is possible that there is a diminution in the number of birds impacted. He stated, "Why has this once destructive force suddenly become so impotent?" Some speculate that birds learn about towers, but this is only speculation. An alternative hypothesis is that the kills continue but there is nobody investigating them as during the 1950s through 1970s. This would be a fertile area for future research. 
Table 2.1. Studies of Tower Kills from the Southeastern and Midwestern United States.

Lists are not exhaustive and are meant to show the reader the range in size of towers and magnitude of kills reported. They were selected from a larger set of studies.

$(\mathrm{n}=$ nights, $\mathrm{mo}=$ months $)$

\section{Southeastern United States}

\begin{tabular}{|c|c|c|c|}
\hline City and State & $\begin{array}{c}\text { Type of Structure/Height (feet) } \\
\text { and Lights (Yes/No) }\end{array}$ & $\begin{array}{l}\text { Number of } \\
\text { Birds }\end{array}$ & Reference \\
\hline Eastern NC & TV Tower - 1,100-1,994 - Yes & $4,000+$ & Carter and Parnell 1976 \\
\hline Chapel Hill, NC & TV Tower $-?-$ Yes & 2,500 & Chamberlain 1957 \\
\hline Chapel Hill, NC & TV Tower - ? - Yes & 2,500 & Newman 1957,1958 \\
\hline Chapel Hill, NC & TV Tower - 788 - Yes & 2,500 & Trott 1957 \\
\hline Charlotte, NC & TV Tower - 1,000 - Yes & 390 & Norwood 1960 \\
\hline Charleston, WV & TV Tower and Microwave - Yes & $1,000 \mathrm{~s}$ & Hall 1966 \\
\hline St. Albans, WV & Microwave Tower - ? - ? & $100 \mathrm{~s}$ & Hall 1968 \\
\hline Nashville, TN & TV Tower - ? - Yes & 990 & Bierly 1973 \\
\hline Morgantown, WV & Fire Tower - ? - No? & "small" & Hall 1975, 1976, 1977 \\
\hline Cape Kennedy, FL & Tower and Buildings - ? - Yes & 2,500 (mo.) & Kale 1971 \\
\hline Crystal River, FL & Chimney - $600 ?-$ Yes & $5,000-2 \mathrm{n}$ & Maher et al. 1983 \\
\hline
\end{tabular}

\section{Midwestern United States}

\begin{tabular}{|c|c|c|c|}
\hline City and State & $\begin{array}{l}\text { Type of Structure/Height (feet) } \\
\text { and Lights (Yes/No) }\end{array}$ & $\begin{array}{l}\text { Number of } \\
\text { Birc }\end{array}$ & Reference \\
\hline Eastern ND & TV Tower - 2,000 - Yes & 561 & Avery and Clement 1972 \\
\hline Eau Claire, WI & TV Tower - ? - Yes & 5,000 & Baird 1962 \\
\hline Eau Claire, WI & TV Tower - ? - Yes & 30,000 & Green 1964 \\
\hline Eau Claire, WI & TV Tower - 1,000 - Yes & $20,000-1 \mathrm{n}$ & Kemper 1958 \\
\hline Eau Claire, WI & TV Tower $-1,000-$ Yes & $30,000-2 \mathrm{n}$ & Kemper 1964 \\
\hline Eau Claire, WI & TV Tower - ? - Yes & $2,000+$ & Robbins 1969 \\
\hline Marysville, MO & Towers - 250-410 - Yes & 71 & Ball 1973 \\
\hline Champaign, IL & TV Tower - 983 - Yes & 486 & Brewer and Ellis 1958 \\
\hline Champaign, IL & TV Tower - 983 - Yes & ? & Cochran and Graber 1958 \\
\hline Springfield, IL & TV Tower - ? - Yes & $827-1 \mathrm{n}$ & Parmalee \& Thompson1963 \\
\hline Springfield, IL & TV Tower - ? - Yes & 219 & Parmalee \& Parmalee 1959 \\
\hline Central IL & 7 TV Towers - 600-1,500 - Yes & 5,500 & Seets and Bohlen 1977 \\
\hline Orion, IL & TV Tower - 983 - yes & 88 & Petersen 1959 \\
\hline
\end{tabular}


Floyd Nobs, IN

South Bend, IN

Cadillac, MI

Ostrander, MN

Ostrander, MN

Lewisville, MN

Youngstown, $\mathrm{OH}$

Dayton, $\mathrm{OH}$

Western Great Lakes
TV Tower - ? - Yes

TV Towers - $650 \& 1,074$ - Yes

TV Tower - 1,295 - Yes

TV Tower - ? - Yes

TV Tower - 1,314 - Yes

TV Tower - ? - Yes

TV Tower - ? - Yes

TV Tower - ? - Yes

Towers - ? - Yes?
78

289

812

1,250

4,000

924

364

348

12,000
Petersen 1968

Manuwal 1963

Caldwell \& Cuthbert 1963

Feehan 1963

Strand 1962

Green 1964

Hall 1975, 1976

Petersen 1968

Lupient 1961 
Table 2.2. List of Tower Kill Studies from the Northeastern United States.

(Maine, New Hampshire, Vermont, Massachusetts, Connecticut, Rhode Island, New York, Pennsylvania, New Jersey, Delaware, and Maryland) and eastern Canada (Ontario, Quebec, and Maritimes $).(\mathrm{n}=$ night, $\mathrm{mo}=$ month $)$

City and State

Type of Structure/Height (feet)Number ofReference and Lights (Yes/No) Birds

\begin{tabular}{|c|c|c|c|}
\hline New York, NY & Building - 1,200 - Yes & $200+$ & Aronoff 1949 \\
\hline Baltimore, MD & Tower - 450 - Yes & $?$ & " \\
\hline Philadelphia, PA & Building - ? - Yes & $?$ & " \\
\hline Boston, MA & Tower? - Yes & $300+$ & Baird et al. 1959 \\
\hline Springfield, MA & Searchlight - N/A & $200+$ & " \\
\hline Elmira, NY & TV Tower - ? - Yes & 3,862 & Benning 1978 \\
\hline Elmira, NY & TV Tower - ? - Yes & $300+$ & Rosche 1970 \\
\hline Elmira, NY & TV Tower - ? - Yes & 220 & Rosche 1971,1972 \\
\hline NW PA & TV Tower - ? - Yes & $1,500+$ & Rosche 1970 \\
\hline Champaign, IL & Tower - $983-$ Yes & 486 & Brewer and Ellis 1958 \\
\hline Allegheny, NY & TV Towers - 200-1,000+ - Yes & $10,000 / \mathrm{yr}$ & Eaton 1967 \\
\hline Elmira, NY & TV Towers - 842 - Yes & 4,000 & Welles 1978 \\
\hline Grand Manaan, NS & Lighthouse - ? - Yes & $1,000+$ & Bagg and Emery 1964 \\
\hline Barrie, ON & TV Tower - ? - Yes & 7,550 & Goodwin 1975 \\
\hline London, ON & TV Tower - ? - Yes & $"$ & $"$ \\
\hline Lennox, ON & Chimney - ? - Yes & $"$ & $"$ \\
\hline Lennox, ON & Chimney - 650 - Floodlights & $5,288-$ & \\
\hline Toronto, $\mathrm{ON}$ & Building - 1,000 - Yes & $136-1 n$ & Goodwin \& Rosche 1971 \\
\hline Pittsburg, PA & TV Tower - ? - Yes & 364 & Hall 1976 \\
\hline Barrie, ON & TV Tower - 1,000+ - Yes & 4,900 & Hoskin 1975 \\
\hline Philadelphia, PA & Buildings - ? - Yes & $1,000 \mathrm{~s}$ & Potter and Murray 1949 \\
\hline Baltimore, MD & TV Tower - 1,000+ - Yes & $1,000-1 \mathrm{n}$ & Scott and Cutler 1965 \\
\hline Baltimore, MD & TV Tower - 1,000+ - Yes & $1,965-1 \mathrm{n}$ & Scott and Cutler 1971 \\
\hline Baltimore, MD & TV Tower $-1,000+-$ Yes & $180-1 \mathrm{n}$ & Scott and Cutler 1972 \\
\hline Toronto, ON & TV Tower - 1,815 - Yes & $274-1 n$ & Whelan 1976 \\
\hline
\end{tabular}


Table 2.3. Wind Turbine Facilities Reviewed by Jacobs (1994) Review of Bird Mortality Associated with Wind Turbines in the Northeastern United States.

Number of Turbines/Size Tower Type Owner/Operator

1. Mt. Equinox, VT, 1989

2 - 100-kW, 3-blade

Lattice

Green Mountain Power Corporation

2. Princeton, MA, 198

8 - 40-kW, 3-blade

Lattice

Princeton Mun. Light Dept.

3. Tug Hill Plateau, NY

2 - 300-kW, 3-blade

Lattice

Niagara Mohawk Power 1992

Corporation

4. Martha's Vineyard, MA, 1981-1982

5. Nantucket, MA, 1980s

9 - 25-kW, 3-blade

Lattice

Unknown

Lattice

1 - 100-kW Vertical Axi

Lattice

Local power co. 


\section{Chapter 3. Description of Searsburg, Vermont, Wind Power Facility}

\section{Project Description}

A total of 11, Zond Z-40 turbines were erected at the Searsburg site. The turbines are rated at 550 kilowatts and the site is rated at about 6 megawatts of power. It will produce approximately 14,000,000 kilowatt-hours annually, enough to supply about 2,000 homes with electricity. Each turbine is situated on a cylindrical tower that offers no perch sites for birds. The nacelles that house the generators are also smooth and offer no perching or nesting opportunities other than the top of the nacelle itself. The height above the ground to the tip of the blades ( 12 o'clock position) is about 197 feet. Turbine rotors are painted black to help shed ice, a potential problem for northern wind power facilities. The area cleared for turbines and roads included about 12 acres (about 5 ha) on site. Of this area, $75 \%$ was deciduous forest and the remainder was coniferous or coniferous and deciduous mixed forest. The coniferous patches were small, consisting of less than one acre $(0.47$ ha).

\section{Ecology and Topography}

The ecology and topography at the Searsburg wind power facility is different from most existing wind plants in the United States and Canada. The Searsburg facility is situated in forested mountains with virtually no clearings other than those created by commercial logging. The site is covered with a rather typical northern hardwood forest dominated by yellow birch, paper birch, sugar and red maple, American beech, black cherry, mountain ash, and others, with an under story of Viburnum and various herbaceous plants. In addition to the typical northern hardwood forest elements, pockets of boreal forest are evident on site, but mostly at the top of the hills. These pockets consist of small stands ( $<<1$ acre [0.47 ha]) of balsam fir that can be dense and sometimes exceed 7-8 $\mathrm{m}$ in height. The forest is privately owned and is logged on a rotational basis. For this reason, most of the trees on site do not exceed 40-50 years in age. Remnants of stumps in excess of $1 \mathrm{~m}$ in diameter are abundant. The area could be construed as decent or good, but not excellent, habitat for forest breeding birds.

The elevational range of the project is from about 2,550 feet $(785 \mathrm{~m})$ above sea level to nearly 2,900 feet (892 m) above sea level. Turbines were installed at 2,700-2,800+ feet (831-862 m). In this area in New England, the boreal, high altitude forest begins to occur at about 3,000 feet (923 $\mathrm{m})$. The turbines are located on the top of a spine of connected hills that can be construed as a short ridge, extending from north to south over about one kilometer. On either side of the spine are very steep hillsides with grades in excess of $20 \%$ in places. Clearings for the turbines are sometimes in excess of $25 \mathrm{~m}$ radius from the turbine, although the vegetation management plan calls for these areas to be naturally revegetated. By the end of the first summer following construction of the turbines, black cherry and red spruce trees were already growing in the turbine clearings, along with many other herbs and woody plants. 


\section{Chapter 4. Nesting Songbirds and Raptors}

\section{Introduction}

Wind turbine development can impact birds in several ways. A primary consideration is direct impact via collision of birds with revolving turbine blades. For songbirds and raptors that nest in forest interior locales, the construction of roads, power lines, and wind turbines can also alter the bird's habitat and thereby impact on reproductive success and, or survival, which in turn impact populations. Roads must be cleared, trees cut, and new structures erected, not to mention the temporary disturbance of work crews. The construction process itself is an ephemeral one that ends after construction is complete. Some of the habitat changes are short lived, while others are for the duration of the project. To determine the impacts of the Searsburg, Vermont wind turbine development on nesting songbirds and raptors, Green Mountain Power Corporation contracted a breeding bird survey during June and early July of 1994, prior to permitting of the project. The project reported in this chapter builds on the 1994 study, using the same methodology and sampling locations. It adds two years of surveys; in 1996 during construction of the roads and turbine pads, and in 1997 after the construction was complete and turbines were operating. This report compares these data sets and makes conclusions regarding type and degree of impact both to the avian community and individual species. From these comparisons, conclusions are made regarding the overall impact of the project and the degree of certainty of these conclusions. In some cases, recommendations are made for addressing questions that arose as a result of these comparisons.

\section{Nesting Raptors}

Although southern Vermont is not known for having a great diversity or high densities of breeding raptors, several species are known to nest in the region (Laughlin and Kibbe 1985). To determine which species, if any, nest on or near the Searsburg wind power facility, Capen and Coker (1994) conducted surveys during the nesting season in 1994 for Green Mountain Power Corporation. In particular, they were searching for Northern Goshawk because the species is a listed species in Vermont. In 16 person/days on site and nearby in spring of 1994 no goshawks or other hawks were found on or near the site, despite the use of a goshawk alarm call broadcast using a tape player. The tape was played at regularly spaced intervals along transects that traversed the project site and the area surrounding the site. A total of $48.4 \mathrm{~km}$ of trails (transects) was surveyed. Capen and Coker also noted that "nothing about the habitat in the study area suggested a particularly unique nesting site for Northern Goshawks."

During songbird surveys in 1996 and 1997 (described below), as well as during birding walks and drives in the area near the site, this observer observed few raptors. No goshawks were observed, although Sharp-shinned Hawks were seen on at least two occasions, as were several Turkey Vultures. One time a single individual came within $500 \mathrm{~m}$ of the site and on another a single individual was observed about $3 \mathrm{~km}$ from the site. A Red-tailed Hawk was observed soaring in the distance, perhaps $2 \mathrm{~km}$ from the site. This species does not nest in large forested tracts, although they do nest at clearings or in edge situations. A Turkey Vulture was seen 
during a breeding bird survey about $200 \mathrm{~m}$ away from an active turbine. Of these species, only the Red-tailed Hawk is known to be a high risk species (from studies in the Altamont WRA) with respect to wind turbines, but is not present on the site often.

\section{Study Area and Methods - Songbirds}

To sample songbird populations on the wind turbine site, 21 point counts were established in 1994 along the trails and roads leading into and through the wind plant. The points were selected by Capen and Coker (1994) to sample the locations proposed in a preliminary site plan for the road and wind turbine locations. Each point was sampled for 5 minutes during which all birds seen or heard were noted. Those birds within a $50 \mathrm{~m}$ radius of the sampling point were noted as such, so that density estimates could be made. Birds outside the $50 \mathrm{~m}$ radius were also noted, but they were noted as distinct from those within the $50 \mathrm{~m}$ radius. The location of the 21 points sampled was established by Capen and Coker (1994), prior to the involvement of the author of this report. A topographic map and a Magellan 2000 GPS (satellite positioning device) were used to locate points in the forest. Because Capen and Coker did not flag their sample points, the location of the 1996 and 1997 points may not be identical to those of the 1994 study. However, the 1996 and 1997 points were identical and were very close to those established in 1994. Changes in the site plan in 1996, with respect to road location, necessitated minor changes in location of the points sampled between 1994 and 1996-1997. These changes were made when points fell in the center of areas that had been cleared. Minor changes were made so that the sites sampled were mostly forested (points not located at center of turbine pad) as was the case during the 1994 study. Locational changes were done to reflect habitat that was nearly identical to that used in the 1994 study.

The rationale for moving original sampling points off cleared areas is that cleared sites cannot be expected to host the species or densities of birds they did when they were forested. The question here is not whether the birds will breed on cleared sites, but whether they will breed in sites adjacent to roads, operating wind turbines, and wind turbine clearings.

Point counts of breeding birds were conducted on June 9, June 16, June 30, July 1 in 1994; June 12, June 30, and July 1 in 1996; and on June 3, June 4, July 1, and July 2 in 1997. These dates are all within 10 days of the dates on which data were collected in 1994 by Capen and Coker. Counts were conducted between 04:55 and about 11:00 EST. All data are reported herein, although for comparison with the Capen and Coker (1994) data set, only two days of surveys were selected from the 1996 and 1997 data sets (one from June and one from July surveys, selected at random via the toss of a coin). Data collected on the extra days during 1996 and 1997 are included in a non-quantitative form, but were not included in the analyses. During the actual field sampling on these dates there was some disturbance from equipment in 1996 (June 3 and 4) at turbine site \#1 and \#2, which is nearest points \#16 and \#17 at the northernmost portion of the wind plant. However, noise was minimal for most of the work. In addition, turbine noise during operation was noted during some observations. Such noise obstructs the observer's hearing of avian vocalizations, especially those birds with high pitched song calling at distances greater than 20 meters from the observer. 


\section{Results}

Forty-two species were observed at the 21 sampling points in 1994, 1996, and 1997 (Tables 4.1, 4.2, 4.3, also see Capen and Coker 1994 ). This includes species observed on a third and fourth sampling day in 1996 and 1997. The number of species observed only on official sampling days within the $50 \mathrm{~m}$ radius sampling area was 31 for 1994, as opposed to 26 in 1996 and 24 in 1997. Thus, species richness was greater before construction than the surveys done during and after construction. Examining the larger area that includes within and beyond the $50 \mathrm{~m}$ sampling circle, species richness was also higher in 1994 with 34 species being observed in that year and only 30 and 25 species being observed in 1996 and 1997 respectively. However, about the same number of species was seen among the years if the two extra days of surveys in 1996 and 1997 are included (Table 4.3). Although this is not an appropriate comparison, it shows that the same species were present after construction but were not recorded during the official sampling period. The apparent difference may be explained either by the fact that construction disturbance and operational disturbance (sound) of the turbines after construction made it more difficult in 1996 and 1997 to detect birds. Just as likely, habitat modification accounted for the lower number of species during and after construction and that the detection of other species on the extra days in 1996 and 1997 is a function of greater sampling period.

The numbers of species seen on each of the 21 point count sites before construction (1994) was compared with the numbers after construction (1997). Although no significant difference was detected when comparing birds within and beyond the $50 \mathrm{~m}$ sampling circle (Sign tests $\mathrm{p}>0.05$ but $<0.10$ ), fewer species were observed after construction. Pooling the degrees of freedom from the two analyses brings the results of the analysis close to the $\mathrm{P}<0.05$ level, which is a strong enough result to make it noteworthy.

The five most common species in descending order of abundance on the 1994 surveys were Slate-colored Junco, Swainson's Thrush, White-throated Sparrow, Ovenbird, and Red-eyed Vireo. After construction in 1997 Yellow-rumped Warbler was most numerous followed by Slate-colored Junco, White-throated Sparrow, Blackpoll Warbler, and Magnolia Warbler in that order. Most of these species are typical of northern or boreal forests with a mixture of deciduous and coniferous vegetation. The abundance of these species in many parts of Vermont, according to the Vermont breeding bird atlas (Laughlin and Kibbe 1985), is similar to or less than the abundances measured in this study (Table 4.3). However, there were changes in the number of individuals of several of these species after construction.

Most notable were the declines in abundance and frequency at point counts of Swainson's Thrush, Ovenbird, Black-throated Blue Warbler, Canada Warbler, Red-eyed Vireo, and Whitethroated Sparrow. All of these species are known as forest nesting species, although vireos and White-throated Sparrows do nest in edge situations, especially where their preferred habitat is abundant in the vicinity (Laughlin and Kibbe 1985). Swainson's Thrush, Ovenbird, Blackthroated Blue Warbler, and Canada Warbler are all species of concern to some environmentalists because they are most often found in interior forest habitats where they enjoy the best nesting success (Partners in Flight Program, National Audubon Society WatchList, etc.). The creation of 
openings in the forests for the turbines and roads is probably responsible for their local decline in abundance in some areas.

Regarding Bicknell's Thrush, a species of recent concern to agencies and environmental groups, the species was found in all three years of study. In 1994, one individual was heard, 1996 two individuals were heard, and in 1997 only on one occasion was the song of this species thought to be heard. The vocalization heard may have been this species, although visual confirmation was not possible and the species sang only twice in the distance. This possible Bicknell's Thrush was heard near only one sampling station. In 1997 the species was not recorded on site, but was heard between stations \#1 and \#2 on US Forest Service land about 75 meters from a trail (near the southernmost meteorology tower where there is dense, but not tall balsam fir. This is nearly the highest point of ground on the entire study site. It is surprising that this species is present on this site because the habitat is not ideal for the species (Able and Noon 1976, Noon 1981). Published accounts state that the species is present in thick, conifer forests at elevations usually exceeding 3,000 feet ASL. In Vermont, this means spruce/fir forests of the Green Mountains. Such forests are present in very small patches on a limited portion of the study site, but the altitude of the site is considerably lower than other nesting sites of the species in southern Vermont. The species was found to breed slightly to the north (Laughlin and Kibbe 1985) of Searsburg in the 1980's, presumably at higher elevations where habitat was more suitable. Future research at proposed wind power facilities should target searches for this species.

Species that remained unchanged in order of their abundance and in overall abundance following construction were Blackpoll Warbler, Magnolia Warbler, Slate-colored Junco, and some others.

At least three species increased abundance following construction: American Robin, Blue Jay, and Yellow-rumped Warbler. All of these species are considered to be edge species, with the possible exception of the warbler. The presence of American Robin and Blue Jay at the turbine sites and along the roads is a direct result of the removal of trees and creation of open areas. These species prefer edge or open forest habitats.

Other edge species are known to frequent the area, if not the sites where the turbines were erected. The cemetery and grassy roadsides, as well as the land just south of the cemetery on Route 8 serves as an immediate source area for edge species. This patch of grass and brush in the midst of this large forested area certainly has hosted edge species for many years and is the source of species like American Robins and Chipping Sparrows that have been observed on the study sites after construction. Other edge type species such as Chestnut-sided Warbler, Redwinged Blackbird, and Common Yellowthroat were present adjacent to the cemetery and on some of the point counts taken near the substation that is located only $50 \mathrm{~m}$ from east edge of the cemetery. Interestingly, point counts taken adjacent to the cemetery had some of the highest species abundance and richness values among the point counts. The reason is the mixing of forest and edge species.

Surprisingly, despite the opening of the canopy around the turbines and along the roads, American Crows and Brown-headed Cowbirds did not increase in abundance or frequency. The few cowbirds that were heard were adjacent to the cemetery, well away from the turbines and 
forest interior. The absence of these species is very encouraging because both have been implicated in declines of forest interior nesting birds. Whether cowbirds and other edge species will colonize the area may not be evident for several years after construction.

\section{Discussion}

Overall, the disturbance, alteration, and clearing of the forest resulting from the construction of turbines at Searsburg appears to have reduced the abundance of several species of forest nesting birds that require large, unbroken tracts of land in which to nest. At the same time, several species that are usually associated with the edge of forests or forests that are fragmented, increased in abundance after construction. These types of reductions in forest interior species have been noted in the United States and Canada for several years and are being blamed on fragmentation of the forest and habitat removal by various forms of development and the disturbance created by such fragmentation via human activity and species that are adapted to such fragmented situations.

There are two other explanations for the apparent declines. First, natural variation of populations is not unknown among forest birds. However, because the species that declined are primarily forest interior nesting species and because the species that increased are edge species, natural variation is not likely. The second explanation is that the sound of the turbines occludes the songs of birds and an observer cannot hear them. On at least two of the days surveyed in 1997, turbine noise was obviously loud enough to "drown out" the delicate vocalizations of such species as Blackpoll and Magnolia Warblers, as well as thrushes and wrens. However, Blackpolls and Magnolia Warblers did not decline. Though this may explain a portion of the reduction, the forest fragmentation explanation fits with the weight of evidence.

The difference among observers should also be noted. Because different observers conducted the before and after construction surveys, there is a possibility that bias may explain some of the difference in species composition and abundance.

Although the wind turbines seem to have fragmented the forests to some degree, the changes to the forest are not irreversible. Because the roadside edges and clearings around the turbines are unsuitable for forest interior species and because they have attracted some edge species, it is imperative that these habitats be managed properly. By allowing roadside edges to revert to brush and small trees, as is called for in the Green Mountain Power Corporation management plan, these areas should become unacceptable to edge species and become more suitable for those species that declined. With brush cutting done on a 3-5 year or more rotation, edge species will find these roadsides less attractive and may discontinue use of these areas. Because cowbirds, Blue Jays, and American Crows are attracted to these habitats and because their presence is deleterious to breeding songbirds through predation and parasitism, management for brush instead of grass along roadsides should be a very high priority. The brush cutting cycle needs to be established such that it permits the brush to grow as tall as possible before it is cut back and to establish a cutting height that is not perceived as an edge or grassy area to birds. 
This may be a delicate balance, but it is a key to reducing the impact of wind turbine developments in forested habitats.

Although differences were evident between the 1997 and 1994 breeding songbird surveys, it is not possible at this time to determine if reductions in some species are permanent. As habitat reverts around the turbines, interior nesting birds may move back to those areas they seem to have abandoned. Now that the construction process is over and human activity consists primarily of light maintenance in most of the wind plant, birds may move into the revegetating areas. To determine if this is the case, it is recommended that another round of breeding bird surveys be conducted at the 21 point count locations in the years 1999 and 2001 to determine if the areas are being recolonized by the species that were shown to decline in 1997.

The Searsburg wind power station is the first such facility in the heavily forested eastern part of North America. Other projects will follow and the experience at Searsburg should be noted. Fragmentation of forests via wind turbine erection can impact interior nesting birds in a adverse manner. The size and number of wind power developments in the future are also of concern with respect to habitat loss and fragmentation. This may become the primary ecological consideration in future wind power developments in these habitats. Whether the impacts at Searsburg are ameliorated over several years as the forest reverts and disturbance from human activity remains low is yet to be determined. At least 4-5 acres (1.6-2.0 ha) of the 12 acres (about $5 \mathrm{ha}$ ) cleared for the turbines should revert to forest/brushland, leaving a total of about 7 acres ( 2.8 ha) as the actual loss of habitat. 


\section{Table 4.1. Birds Detected on 21 Point-Count Sites at GMP Searsburg Wind Power Project Site, June-July 1996.}

Species listed in parentheses were also seen at these locations, but not on official count days. These latter dates include 6/11/96 during study site layout and 6/30/96 (indicated by *) during wind, mist, and rain. See Table 4.3 for species codes/abbreviations.

Plot No. Date $<50 \mathrm{~m} \quad$ Birds Detected

\begin{tabular}{llll}
\hline 1. & $6 / 12$ & Y & BLPW WTSP MAWA SCJU YRWA \\
1. & $6 / 12$ & N & YRWA SCJU HETH-2 \\
1. & $7 / 1$ & Y & SWTH WTSP BLPW YRWA \\
1. & $7 / 1$ & N & \\
2. & $6 / 12$ & Y & YRWA \\
2. & $6 / 12$ & N & WTSP \\
2. & $7 / 1$ & Y & MAWA BLPW YRWA WTSP AMRE \\
2. & $7 / 1$ & N & WTSP \\
3. & $6 / 12$ & Y & YRWA SCJU \\
3. & $6 / 12$ & N & BLPW SCJU \\
3. & $7 / 1$ & Y & BTBW (WIWR* CAWA*) \\
3. & $7 / 1$ & N & \\
4. & $6 / 12$ & Y & WIWR BLPW WTSP RBNU \\
4. & $6 / 12$ & N & YRWA WTSP \\
4. & $7 / 1$ & Y & MAWA YRWA BLBW BLPW (GCKI?*) \\
4. & $7 / 1$ & N & \\
5. & $6 / 12$ & Y & BLPW-2 WIWR YRWA (GCTH? SWTH) \\
5. & $6 / 12$ & N & WIWR BTNW YRWA \\
5. & $7 / 1$ & Y & BLPW YRWA-2 WTSP \\
5. & $7 / 1$ & N & HETH WTSP MAWA \\
6. & $6 / 12$ & Y & MAWA WIWR SCJU \\
6. & $6 / 12$ & N & SWTH WIWR YRWA \\
6. & $7 / 1$ & Y & SWTH PUFI (BLPW* BLBW) \\
6. & $7 / 1$ & N & MAWA (BLPW*) \\
7. & $6 / 12$ & Y & MAWA YRWA BLBW WTSP \\
7. & $6 / 12$ & N & MAWA YRWA \\
7. & $7 / 1$ & Y & WTSP MAWA YRWA BTBW SCJU \\
7. & $7 / 1$ & N & WIWR? (SWTH*) \\
8. & $6 / 12$ & Y & MAWA YRWA REVI SCJU \\
8. & $6 / 12$ & N & SCJU HETH WTSP MAWA \\
8. & $7 / 1$ & Y & MAWA YRWA (BTBW* WTSP) \\
8. & $7 / 1$ & N & SCJU SWTH \\
9. & $6 / 12$ & Y & SWTH BLPW MAWA \\
9. & $6 / 12$ & N & CAWA \\
9. & $7 / 1$ & Y & SCJU SOVI? YRWA \\
9. & $7 / 1$ & N & OVEN SCJU REVI \\
& & & \\
\hline & & &
\end{tabular}


Plot No. Date $<50 \mathrm{~m} \quad$ Birds Detected

\begin{tabular}{|c|c|c|c|}
\hline 10 & $6 / 12$ & $\mathrm{Y}$ & WTSP SWTH BTNW YRWA \\
\hline 10. & $6 / 12$ & $\mathrm{~N}$ & WTSP YRWA SCJU RUGR \\
\hline 10. & $7 / 1$ & Y & SCJU-2 (PUFI* BLPW) \\
\hline 10. & $7 / 1$ & $\mathrm{~N}$ & SCJU REVI OVEN \\
\hline 11. & $6 / 12$ & Y & RBNU BLPW BCCH OVEN SWTH SCJU YRWA \\
\hline 11. & $6 / 12$ & $\mathrm{~N}$ & BLJA SCJU-2 YRWA \\
\hline 11. & $7 / 1$ & $\mathrm{Y}$ & SCJU YRWA MAWA OVEN BTBW (HAWO* BTNW*) \\
\hline 11. & $7 / 1$ & $\mathrm{~N}$ & \\
\hline 12. & $6 / 12$ & Y & WTSP-2 WIWR SCJU BLPW-2 HETH MAWA (CAWA BCCH) \\
\hline 12. & $6 / 12$ & $\mathrm{~N}$ & SWTH-2 WIWR WTSP BLBW SCJU-2 YRWA BLPW \\
\hline 12. & $7 / 1$ & $\mathrm{Y}$ & SCJU YRWA WTSP BLPW \\
\hline 12. & $7 / 1$ & $\mathrm{~N}$ & GCTH? SWTH YRWA WTSP \\
\hline 13. & $6 / 12$ & $\mathrm{Y}$ & BLPW-2 WTSP YRWA-2 MAWA SCJU PUFI (CAWA) \\
\hline 13. & $6 / 12$ & $\mathrm{~N}$ & BLPW SWTH HETH YBSA? OVEN \\
\hline 13. & $7 / 1$ & $\mathrm{Y}$ & WTSP-2 \\
\hline 13. & $7 / 1$ & $\mathrm{~N}$ & \\
\hline 14. & $6 / 12$ & $\mathrm{Y}$ & BLPW-2 REVI MAWA WTSP YRWA ( SCJU) \\
\hline 14. & $6 / 12$ & $\mathrm{~N}$ & YRWA OVEN MAWA WTSP \\
\hline 14. & $7 / 1$ & $\mathrm{Y}$ & SWTH BLPW REVI BLJA \\
\hline 14. & $7 / 1$ & $\mathrm{~N}$ & OVEN MAWA \\
\hline 15. & $6 / 12$ & $\mathrm{Y}$ & MAWA-2 YRWA BTNW \\
\hline 15. & $6 / 12$ & $\mathrm{~N}$ & WTSP-2 YRWA BTNW CAWA \\
\hline 15. & $7 / 1$ & $\mathrm{Y}$ & BLPW MAWA REVI \\
\hline 15. & $7 / 1$ & $\mathrm{~N}$ & BLJA MAWA \\
\hline 16. & $6 / 12$ & Y & BTNW MAWA YRWA CAWA (SOVI?) \\
\hline 16. & $6 / 12$ & $\mathrm{~N}$ & MAWA SWTH OVEN SCJU \\
\hline 16. & $7 / 1$ & $\mathrm{Y}$ & BCCH SCJU MAWA \\
\hline 16. & $7 / 1$ & $\mathrm{~N}$ & BLJA SWTH SCJU \\
\hline 17. & $6 / 12$ & Y & YRWA-2 BLPW \\
\hline 17. & $6 / 12$ & $\mathrm{~N}$ & OVEN SWTH SCJU BLJA BLPW \\
\hline 17. & $7 / 1$ & $\mathrm{Y}$ & SCJU (SWTH* BLBW*) \\
\hline 17. & $7 / 1$ & $\mathrm{~N}$ & SCJU \\
\hline 18. & $6 / 12$ & $\mathrm{Y}$ & SWTH OVEN \\
\hline 18. & $6 / 12$ & $\mathrm{~N}$ & AMRO OVEN REVI SCJU (DOWO? BCCH AMRE) \\
\hline 18. & $7 / 1$ & $\mathrm{Y}$ & BLJA OVEN \\
\hline 18. & $7 / 1$ & $\mathrm{~N}$ & SWTH-2 REVI BTBW RBGR \\
\hline
\end{tabular}


Plot No. Date $<50 \mathrm{~m} \quad$ Birds Detected

19. $6 / 12 \quad \mathrm{Y} \quad$ REVI (SCJU)

19. 6/12 N REVI OVEN BCCH SWTH MAWA BTBW

19. $7 / 1 \quad \mathrm{Y}$ OVEN BTBW BAWW REVI

19. $7 / 1 \quad \mathrm{~N}$ BTNW REVI OVEN-2 AMRO BTBW

20. $6 / 12$ Y REVI YRWA BTNW AMRE

20. 6/12 N OVEN SCJU BTBW SOVI

20. $\quad 7 / 1 \quad$ Y $\quad$ REVI SOVI (MAWA*)

20. $7 / 1 \quad \mathrm{~N}$ REVI SCJU OVEN AMCR

21. 6/12 Y SCJU-2 COYE AMRO REVI CEWA CSWA

21. 6/12 N SCJU-2 WTSP REVI CSWA BAWW

21. $7 / 1$ Y AMRE-2 AMRO GRCA COYE REVI SCJU

21. $7 / 1$ N SCJU-2 AMRO AMRE (BLBW* 


\section{Table 4.2. Birds Detected on 21 Point-Count Sites at GMP Searsburg Wind Power Project Site, June 4 and July 1, 1997.}

Species listed in parentheses were also seen at these locations, but not on official count days. These latter dates include June 3, 1997 and July 2, 1997. See Table 4.3 for species codes/abbreviations.

Plot No. Date $<50 \mathrm{~m}$ Birds Detected

\begin{tabular}{|c|c|c|c|}
\hline 1. & $6 / 4$ & Y & BLPW YRWA-2 WTSP SCJU (MAWA-2) \\
\hline 1. & $6 / 4$ & $\mathrm{~N}$ & OVEN SCJU \\
\hline 1. & $7 / 1$ & Y & RBNU BLPW MAWA BTBW YRWA-2 PUFI-2 SCJU (WTSP) \\
\hline 1. & $7 / 1$ & $\mathrm{~N}$ & WIWR YRWA SWTH (SCJU) \\
\hline 2. & $6 / 4$ & $\mathrm{Y}$ & \\
\hline 2. & $6 / 4$ & $\mathrm{~N}$ & (SCJU) \\
\hline 2. & $7 / 1$ & Y & BLBW YRWA SCJU (RBNU BLPW PUFI) \\
\hline 2. & $7 / 1$ & $\mathrm{~N}$ & \\
\hline 3. & $6 / 4$ & $\mathrm{Y}$ & CAWA YRWA SCJU (BLPW) \\
\hline 3. & $6 / 4$ & $\mathrm{~N}$ & \\
\hline 3. & $7 / 1$ & Y & BLBW YRWA (MAWA) \\
\hline 3. & $7 / 1$ & $\mathrm{~N}$ & YRWA (OVEN) \\
\hline 4. & $6 / 4$ & Y & MAWA YRWA (BLPW) \\
\hline 4. & $6 / 4$ & $\mathrm{~N}$ & \\
\hline 4. & $7 / 1$ & $\mathrm{Y}$ & BLPW MAWA YRWA (BLJA SCJU WTSP) \\
\hline 4. & $7 / 1$ & $\mathrm{~N}$ & YRWA \\
\hline 5. & $6 / 4$ & $\mathrm{Y}$ & (YRWA MAWA WTSP) \\
\hline 5. & $6 / 4$ & $\mathrm{~N}$ & \\
\hline 5. & $7 / 1$ & Y & SWTH YRWA WTSP (BLPW GCKI SCJU) \\
\hline 5. & $7 / 1$ & $\mathrm{~N}$ & WTSP (HAWO SCJU) \\
\hline 6. & $6 / 4$ & Y & (BLPW WTSP SCJU) \\
\hline 6. & $6 / 4$ & $\mathrm{~N}$ & \\
\hline 6. & $7 / 1$ & $\mathrm{Y}$ & YRWA SCJU (OVEN BTNW) \\
\hline 6. & $7 / 1$ & $\mathrm{~N}$ & YRWA SCJU \\
\hline 7. & $6 / 4$ & Y & SCJU \\
\hline 7. & $6 / 4$ & $\mathrm{~N}$ & WTSP \\
\hline 7. & $7 / 1$ & Y & BLPW YRWA WTSP SCJU (BLBW) \\
\hline 7. & $7 / 1$ & $\mathrm{~N}$ & YRWA SCJU (HETH SCJU) \\
\hline 8. & $6 / 4$ & Y & SCJU \\
\hline 8. & $6 / 4$ & $\mathrm{~N}$ & WTSP \\
\hline 8. & $7 / 1$ & $\mathrm{Y}$ & MAWA YRWA SCJU (BCCH BLPW) \\
\hline 8. & $7 / 1$ & $\mathrm{~N}$ & (SCJU-2) \\
\hline 9. & $6 / 4$ & $\mathrm{Y}$ & CAWA BLPW WTSP SCJU (OVEN MAWA YRWA) \\
\hline 9. & $6 / 4$ & $\mathrm{~N}$ & WTSP (YRWA AMRE) \\
\hline 9. & $7 / 1$ & $\mathrm{Y}$ & SWTH BLPW CAWA YRWA-2 WTSP SCJU (REVI) \\
\hline
\end{tabular}


Plot No. Date $<50 \mathrm{~m}$ Birds Detected

\begin{tabular}{llll}
\hline 9. & $7 / 1$ & N & HETH BLPW YRWA (BLJA AMRO WTSP) \\
10 & $6 / 4$ & Y & BPWA SCJU (AMRO) \\
10. & $6 / 4$ & N & OVEN YRWA WTSP \\
10. & $7 / 1$ & Y & HETH YRWA SCJU (AMRO REVI OVEN) \\
10. & $7 / 1$ & N & AMRO SCJU (BCCH BLBW) \\
11. & $6 / 4$ & Y & AMRO MAWA CAWA BLPW YRWA (HAWO OVEN WIWR HETH) \\
11. & $6 / 4$ & N & CAWA AMRE OVEN SCJU PUFI (WIWR) \\
11. & $7 / 1$ & Y & BLJA BCCH WIWR AMRO YRWA BTNW WTSP SCJU \\
11. & $7 / 1$ & N & WIWR MAWA PUFI SCJU \\
12. & $6 / 4$ & Y & BLPW YRWA (HETH BCCH BTNW CAWA) \\
12. & $6 / 4$ & N & MAWA BLPW YRWA WTSP SCJU (AMRO) \\
12. & $7 / 1$ & Y & BLPW YRWA-2 (BCCH AMRO PUFI SCJU) \\
12. & $7 / 1$ & N & SCJU (WTSP) \\
13. & $6 / 4$ & Y & CAWA BTBW BLPW SCJU-2 (YRWA) \\
13. & $6 / 4$ & N & BCCH MAWA YRWA WTSP SCJU (SWTH) \\
13. & $7 / 1$ & Y & YRWA (BTBW BLBW WTSP SCJU) \\
13. & $7 / 1$ & N & BLJA YRWA (SWTH SCJU) \\
14. & $6 / 4$ & Y & MAWA BLPW YRWA SCJU (HETH CAWA) \\
14. & $6 / 4$ & N & MODO AMRO YRWA MAWA RBGB (WTSP) \\
14. & $7 / 1$ & Y & CAWA YRWA SCJU (SOVI) \\
14. & $7 / 1$ & N & BTBW (YRWA WTSP) \\
15. & $6 / 4$ & Y & BCCH HETH OVEN SCJU (BAWW YRWA WTSP) \\
15. & $6 / 4$ & N & RBNU BLPW SCJU \\
15. & $7 / 1$ & Y & SCJU BRCR (YBSA CEWA SWTH YRWA WTSP) \\
15. & $7 / 1$ & N & (YRWA WTSP) \\
16. & $6 / 4$ & Y & MAWA-2 WTSP (BCCH OVEN SCJU) \\
16. & $6 / 4$ & N & BLPW \\
16. & $7 / 1$ & Y & BLJA (OVEN BAWW BLBW) \\
16. & $7 / 1$ & N & HETH BLPW (SWTH) \\
17. & $6 / 4$ & Y & BTNW (MAWA BLBW YRWA) \\
17. & $6 / 4$ & N & (RBGB) \\
17. & $7 / 1$ & Y & BAWW BLBW BTNW YRWA WTSP (OVEN) \\
17. & $7 / 1$ & N & BLPW SCJU (REVI MAWA YRWA) \\
18. & $6 / 4$ & Y & HETH SWTH BTBW SCJU (WTSP) \\
18. & $6 / 4$ & N & REVI BTNW SCJU \\
18. & $7 / 1$ & Y & BTNW (HAWO HETH REVI PUFI) \\
18. & $7 / 1$ & N & BCCH BAWW (BLJA BTNW)
\end{tabular}


Plot No. Date $<50 \mathrm{~m}$ Birds Detected

\begin{tabular}{llll}
\hline 19. & $6 / 4$ & Y & REVI BTBW SCJU (BTNW-2) \\
19. & $6 / 4$ & N & HETH-2 SOVI BTNW (AMRO REVI) \\
19. & $7 / 1$ & Y & OVEN BTBW (AMGO GCKI SCJU) \\
19. & $7 / 1$ & N & BTBW RBGB (REVI YRWA OVEN SCJU) \\
20. & $6 / 4$ & Y & $\begin{array}{l}\text { MODO REVI BAWW BTNW PUFI SCJU (SOVI BTBW OVEN } \\
\end{array}$ \\
20. & $6 / 4$ & N & YRWA) \\
20. & $7 / 1$ & Y & AMRO HETH BTNW CSWA CHSP SCJU (WTSP OVEN PUFI) \\
20. & $7 / 1$ & N & REVI (OVEN PIWW BTNW AMRE YRWA) \\
21. & $6 / 4$ & Y & REVI-2 BTNW CSWA YRWA WTSP PUFI SCJU (RWBB AMRO) \\
21. & $6 / 4$ & N & HETH REVI YRWA (AMRO OVEN CHSP BTBW) \\
21. & $7 / 1$ & Y & AMRO REVI CSWA-2 - poss BHCO RWBB (COYE) \\
21. & $7 / 1$ & N & (AMRO BTNW REVI AMRE)
\end{tabular}




\section{Table 4.3. Birds Detected on 21 Sampling Points in the Green Mountain Power Searsburg Wind Power Forest Nesting Birds Study, June 1994, 1997.}

Number is the total number seen or heard within and beyond the $50 \mathrm{~m}$ radius at each point, frequency is the number of points $(<50 \mathrm{~m}$ from the point and $>50 \mathrm{~m}$ ) at which the species was detected, and abundance is the number of nesting pairs per hectare calculated from the number seen within the $50 \mathrm{~m}$ sampling point radius. An asterisk means that the species was seen or heard at the point, but not on the two official count days. The 1994 data set is from Capen and Coker (1994).

Species Name-Species Code

1994*

1996

1997

Number Frequency Abundance Number Frequency Abundance Number Frequency Abundance

$\begin{array}{llrrrrrrrrr}\text { American Crow } & \text { AMCR } & 3 & 2 & 0.000 & 1 & 1 & 0.000 & 0 & 0 & 0.000 \\ \text { American Goldfinch } & \text { AMGO } & 0 & 0 & 0.000 & 0 & 0 & 0.000 & * & * & 0.000 \\ \text { American Redstart } & \text { AMRE } & 3 & 3 & 0.182 & 5 & 3 & 0.243 & 3 & 3 & 0.061 \\ \text { American Robin } & \text { AMRO } & 2 & 1 & 0.000 & 4 & 3 & 0.061 & 5 & 5 & 0.183 \\ \text { Baltimore Oriole } & \text { NOOR } & 1 & 1 & 0.061 & 0 & 0 & 0.000 & 0 & 0 & 0.000 \\ \text { Black-and-White Warbler } & \text { BAWW } & 5 & 5 & 0.303 & 2 & 2 & 0.061 & 3 & 3 & 0.121 \\ \text { Black-capped Chickadee } & \text { BCCH } & 2 & 2 & 0.121 & 3 & 3 & 0.121 & 4 & 4 & 0.121 \\ \text { Blackburnian Warbler } & \text { BLBW } & 3 & 3 & 0.121 & 3 & 3 & 0.121 & 3 & 3 & 0.183 \\ \text { Blackpoll Warbler } & \text { BLPW } & 12 & 8 & 0.667 & 19 & 12 & 0.909 & 13 & 11 & 0.485 \\ \text { Black-throated Blue Warbler } & \text { BTBW } & 17 & 12 & 0.667 & 6 & 5 & 0.242 & 8 & 6 & 0.364 \\ \text { Black-throated Green Warbler } & \text { BTNW } & 9 & 9 & 0.243 & 7 & 6 & 0.242 & 8 & 6 & 0.243 \\ \text { Blue Jay } & \text { BLJA } & 1 & 1 & 0.061 & 6 & 6 & 0.121 & 3 & 3 & 0.121 \\ \text { Brown Creeper } & \text { BRCR } & 0 & 0 & 0.000 & 0 & 0 & 0.000 & 1 & 1 & 0.061 \\ \text { Brown-headed Cowbird } & \text { BHCO } & 1 & 1 & 0.061 & 0 & 0 & 0.000 & 1 & 0 & 0.061 \\ \text { Canada Warbler } & \text { CAWA } & 15 & 11 & 0.727 & 3 & 3 & 0.061 & 6 & 5 & 0.303 \\ \text { Cedar Waxwing } & \text { CEDW } & 1 & 1 & 0.061 & 1 & 1 & 0.061 & * & * & 0.000 \\ \text { Chimney Swift } & \text { CHSW } & 1 & 1 & 0.061 & 0 & 0 & 0.000 & 0 & 0 & 0.000 \\ \text { Chipping Sparrow } & \text { CHSP } & 0 & 0 & 0.000 & 0 & 0 & 0.000 & 1 & 1 & 0.000\end{array}$




\begin{tabular}{|c|c|c|c|c|c|c|c|c|c|c|}
\hline Common Yellowthroat & COYE & 1 & 1 & 0.061 & 1 & 1 & 0.061 & $*$ & $*$ & 0.000 \\
\hline Chestnut-sided Warbler & CSWA & 3 & 1 & 0.121 & 2 & 1 & 0.061 & 3 & 2 & 0.121 \\
\hline Downy Woodpecker & DOWO & 0 & 0 & 0.000 & $*$ & $*$ & 0.000 & $*$ & $*$ & 0.000 \\
\hline Gray-cheeked Thrush & GCTH & 1 & 1 & 0.061 & 2 & 2 & 0.061 & $*$ & $*$ & 0.000 \\
\hline Golden-crowned Kinglet & GCKI & 1 & 1 & 0.061 & $*$ & $*$ & 0.000 & $*$ & $*$ & 0.000 \\
\hline Hairy Woodpecker & HAWO & 0 & 0 & 0.000 & $*$ & $*$ & 0.000 & $*$ & $*$ & 0.000 \\
\hline Hermit Thrush & HETH & 7 & 5 & 0.121 & 6 & 5 & 0.121 & 9 & 8 & 0.182 \\
\hline Magnolia Warbler & MAWA & 11 & 8 & 0.488 & 22 & 15 & 0.848 & 11 & 8 & 0.424 \\
\hline Ovenbird & OVEN & 21 & 13 & 0.667 & 13 & 10 & 0.182 & 6 & 6 & 0.182 \\
\hline
\end{tabular}


Table 4.3. continued

Species Name -Species Code

1994*

1996

1997

Number Frequency Abundance Number Frequency Abundance Number Frequency Abundance

\begin{tabular}{|c|c|c|c|c|c|c|c|c|c|c|}
\hline Pileated Woodpecker & PIWO & 0 & 0 & 0.000 & 0 & 0 & 0.000 & $*$ & $*$ & 0.000 \\
\hline Purple Finch & PUFI & 4 & 4 & 0.182 & 2 & 2 & 0.121 & 5 & 4 & 0.243 \\
\hline Red-eyed Vireo & REVI & 17 & 10 & 0.424 & 12 & 9 & 0.424 & 6 & 3 & 0.243 \\
\hline Red-breasted Nuthatch & RBNU & 2 & 2 & 0.061 & 2 & 2 & 0.121 & 2 & 2 & 0.061 \\
\hline Red-winged Blackbird & RWBB & 0 & 0 & 0.000 & 0 & 0 & 0.000 & $*$ & $*$ & 0.000 \\
\hline Rose-breasted Grosbeak & RBGB & 1 & 1 & 0.061 & 1 & 1 & 0.000 & $*$ & $*$ & 0.000 \\
\hline Ruffed Grouse & RUGR & 1 & 1 & 0.061 & 1 & 1 & 0.000 & 0 & 0 & 0.000 \\
\hline Scarlet Tanager & SCTA & 1 & 1 & 0.000 & 0 & 0 & 0.000 & 0 & 0 & 0.000 \\
\hline Slate-colored Junco & SCJU & 25 & 15 & 0.970 & 29 & 15 & 0.848 & 29 & 18 & 1.031 \\
\hline Solitary Vireo & SOVI & 3 & 3 & 0.182 & 3 & 2 & 0.121 & $*$ & $*$ & 0.000 \\
\hline Swainson's Thrush & SWTH & 24 & 15 & 0.606 & 16 & 13 & 0.424 & 4 & 4 & 0.182 \\
\hline Winter Wren & WIWR & 6 & 5 & 0.061 & 8 & 5 & 0.242 & 3 & 2 & 0.061 \\
\hline White-throated Sparrow & WTSP & 22 & 15 & 0.727 & 22 & 12 & 0.667 & 14 & 11 & 0.485 \\
\hline Yellow-bellied Sapsucker & YBSA & 0 & 0 & 0.000 & 1 & 1 & 0.000 & $*$ & $*$ & 0.000 \\
\hline Yellow-rumped Warbler & YRWA & 15 & 14 & 0.727 & 29 & 17 & 1.150 & 32 & 17 & 1.213 \\
\hline
\end{tabular}

1994 data from Capen and Coker 1994, recalculated for comparison with 1996 and 1997 data set.

* Indicates species was seen on one of two non-official counts 
Table 4.4. Comparison of Species Richness/Diversity (Number of Species) for Each of 21 Sampling Points in 1994 (Preconstruction), 1996 (During Construction), and 1997 (Post-Construction).

Three asterisks indicate species seen on 11 and 30 June 1996 and 4 June and 2 July 1997 (days which were not part of the official survey used to calculate frequency or abundance data in Table 4.3).

\begin{tabular}{|c|c|c|c|c|c|c|c|c|}
\hline \multirow[t]{2}{*}{ Transect Number } & \multicolumn{2}{|c|}{ Number of Species } & \multicolumn{3}{|c|}{ Number of Species } & \multicolumn{3}{|c|}{$\underline{1997}$} \\
\hline & $<50 \mathrm{~m}$ & $>50 \mathrm{~m}$ & $<50 \mathrm{~m}$ & $>50 \mathrm{~m}$ & $* * *$ & $<50 \mathrm{~m}$ & & $* * *$ \\
\hline 1. & 7 & 12 & 6 & 7 & 7 & 9 & 11 & 11 \\
\hline 2. & 5 & 7 & 5 & 5 & 5 & 3 & 3 & 6 \\
\hline 3. & 7 & 10 & 2 & 2 & 4 & 4 & 5 & 7 \\
\hline 4. & 4 & 6 & 7 & 7 & 8 & 3 & 3 & 6 \\
\hline 5. & 4 & 4 & 4 & 7 & 8 & 3 & 3 & 8 \\
\hline 6. & 10 & 11 & 6 & 6 & 8 & 2 & 2 & 6 \\
\hline 7. & 8 & 10 & 6 & 7 & 8 & 4 & 4 & 6 \\
\hline 8. & 6 & 6 & 5 & 7 & 8 & 3 & 4 & 6 \\
\hline 9. & 9 & 12 & 5 & 8 & 8 & 6 & 7 & 12 \\
\hline 10. & 6 & 9 & 5 & 8 & 10 & 4 & 7 & 10 \\
\hline 11. & 9 & 10 & 8 & 10 & 12 & 11 & 14 & 16 \\
\hline 12. & 4 & 7 & 7 & 9 & 11 & 2 & 5 & 12 \\
\hline 13. & 7 & 8 & 6 & 9 & 10 & 5 & 9 & 11 \\
\hline 14. & 8 & 11 & 7 & 7 & 9 & 5 & 10 & 13 \\
\hline 15. & 8 & 8 & 5 & 8 & 8 & 4 & 6 & 13 \\
\hline 16. & 9 & 10 & 6 & 9 & 10 & 3 & 5 & 11 \\
\hline 17. & 5 & 6 & 3 & 6 & 7 & 5 & 7 & 10 \\
\hline 18. & 4 & 8 & 3 & 8 & 11 & 5 & 8 & 12 \\
\hline 19. & 4 & 6 & 5 & 9 & 10 & 4 & 8 & 13 \\
\hline 20 . & 5 & 12 & 5 & 8 & 9 & 10 & 14 & 21 \\
\hline 21. & 8 & 10 & 7 & 9 & 10 & 10 & 10 & 16 \\
\hline
\end{tabular}




\section{Table 4.5. Summary of Species Richness Among Years at Searsburg, Vermont, 1994, 1996, and 1997.}

Number in parentheses represents the number of species seen on standard survey plus two other survey days that were done during those years.

Number of Species Found/Richness

$\begin{array}{llll} & \underline{1994} & \underline{1996} & \underline{1997} \\ <50 \mathrm{~m} & 31 & 26 & 24 \\ <50 \&>50 \mathrm{~m} & 34 & 30(33) & 25(37)\end{array}$




\section{Chapter 5. Nocturnal Migration of Songbirds: Spring and Autumn}

\section{Introduction}

Although tall towers, especially those that are lighted and exceed 300-400 feet, are known to impact upon migrating songbirds, little is known about the impact of wind turbines on these birds. Because wind turbines enter the lower portion of the altitudinal strata used by migrants, it is possible that they do pose a threat. In this chapter, a study of the nocturnal migration of songbirds at the Searsburg, Vermont, wind power site during two spring and two autumn migration seasons is detailed. The studies include numbers of migrants, their flight direction, and behavior at the Searsburg site as determined with a ceilometer. The study was designed so that one season of migration (spring and autumn) was observed prior to construction of the windplant and one season (spring and autumn) was observed after construction, permitting comparison of numbers of birds and their behavior before and after the turbines were in place. In addition, the numbers recorded can be compared to the numbers reported from other locations including some that are known to be migration hot spots. These latter comparisons can be used to predict relative risk to migrants at different locations. The assumption is that wind turbines situated at sites where migrants occur in large numbers pose a greater risk than those at sites where migrants are scarce.

\section{Background on the Nocturnal Migration of Songbirds}

During spring and autumn in North America, millions of songbirds undertake migrations between their breeding and wintering sites. Most migrate during the night (Kerlinger and Moore 1989), along with other nocturnal migrants including waterfowl, herons and egrets, owls, and shorebirds (Kerlinger 1989, 1995c). Birds that use soaring flight during migration such as hawks, gulls, pelicans, and others migrate during daytime (Kerlinger 1989, Moore and Kerlinger 1989). Soaring flight is flight without flapping in which birds use updrafts to stay aloft.

Nocturnal migrants like songbirds take off shortly after sunset (30 minutes to one hour), climb to their cruising altitude, fly for one to 12 hours, descend, and land. During this process migrants climb and descend through the first 200 feet above the ground, the height of most wind turbines. Flight in this altitudinal range occurs for only a small portion of their nightly flights. Most of the night is spent cruising at between 300 and 2,000 feet. Scientists who study migration are in agreement that a majority of migrants fly within this altitudinal band, especially over land (Kerlinger 1995c).

To determine whether a given wind power project will impact upon migrants, planners need to know more about the numbers of birds that pass through the project area and at what altitude they pass. In addition, the numbers of migrants determined to migrate at a proposed site must be compared with migration at other sites, particularly known migration hot spots. If large numbers of birds migrate at low altitudes in an area, the potential for adverse impacts to occur is greater than if comparatively few birds move through. 
The birds that migrate over Searsburg at night are primarily songbirds, with some shorebirds, waterfowl, and other species mixed in. A large proportion of those songbirds are Neotropical migrants that fly to and from the Central and South America and the Caribbean Basin. These birds are now of particular interest because the populations of some species are declining. The types of Neotropical and non-Neotropical songbird migrants that fly over southern Vermont are summarized in Table 5.1.

\section{Methods}

The songbird migration study was conducted in Searsburg, Vermont in spring (May) 1995 and 1997 and in autumn (late August through early November) 1996 and 1997, at the site of Green Mountain Power Corporation's wind power facility. The actual study location approximates where turbine number 6 is now situated at an elevation of about 2,800 feet ASL (see Green Mountain Power Corporation Petition of Public Good, Vermont Public Service Board, 1995, for map of wind turbine locations). Dates of the study correspond to the peak of spring and autumn migration for Neotropical and North America songbird migrants. At these times, songbirds are flying to or returning from the southern and central United States, Central America, South America, and the Caribbean basin.

To estimate the numbers of migrants aloft and their flight direction, a standard ceilometer was used. For the present study a 12-volt, 400,000 candlepower spotlight (Brinkman Q-Beam, "Black Max") was used. Power was supplied by a gas generator in spring 1995 and via an automobile battery, thereafter (while the automobile engine was running). The ceilometer is aligned vertically with the aid of a bubble level. An observer reclines on his/her back and looks through a 20 power spotting scope that is also aligned vertically. By separating the spotting scope and the ceilometer by about 25-50 feet, insects that often fly in the lowest portion of the beam are not evident.

The ceilometer illuminates the underside of a migrant as it flies through the beam. Birds flying through a ceilometer beam are easily spotted. Their wings, tails, heads, and even breast spots at times are clearly visible. With the 400,000 candle-power ceilometer used in this study, birds the size of thrushes are visible to more than 600 feet and sometimes to more than 1,200 feet.

Flight direction is determined by recording clock face coordinates of the bird as it flies through the ceilometer beam. For example, with the observer looking upward in the prone position with head aligned to the north ( 12 o'clock), a bird seen flying from 6 o'clock to 12 o'clock is flying north. A bird seen flying from 3 o'clock to 9 o'clock is flying to the east and one flying from 9 to 3 is flying west.

When the moon was too bright for the Q-beam to be effective (one-half and three quarter moon in this study), moonwatching was substituted for ceilometer observations. Moon watching for migrants is done by focusing a 20x spotting scope on the moon's disk. Birds can be seen crossing the moon in a fashion similar to the ceilometer. Directions are read off a clock face that the viewer superimposes over the moon's disk. These clock face coordinates are translated into 
actual directions $\left(0-360^{\circ}\right)$ via a table that compensates for the moon's changing azimuth and angle above the horizon. This occurred on only two evenings during the study.

At or shortly after about 45-60 minutes after sunset, ceilometer observations commenced. This period corresponds to the takeoff time and peak timing of migration for most night migrating songbirds. In addition, because it is so close to takeoff time, these birds would be flying at their lowest altitude and be readily visible. Four 15 minute periods of observation per night were used, separated by up to 10 minutes of rest period between them. Not all observers used the entire rest time allotted. For the purpose of this study all four 15 minute observation periods per night were pooled. Thus, unless adverse weather curtailed operations, observations occurred during one hour each evening. Operations were completed by a few minutes after 10:00 p.m. EDT in spring and somewhat earlier in autumn, in most instances.

Rudimentary weather data were gathered at the beginning of observations each evening and were noted if and when weather changed during an evening's observations. Wind direction and speed, approximate temperature, and cloud cover were noted. In addition, precipitation was noted. Operations were terminated when rain commenced during field work. The sample size did not permit examination of weather effects on nocturnal migration.

\section{Results and Discussion}

Observations at Searsburg were conducted on 14 nights in each of four migration seasons (for dates see Tables 5.2, 5.3, 5.4, 5.5). A total of about 14 hours of observations was logged during each season, although in one year the total was only 13.75 hours, and in another it was about 15 hours. During the study, rain precluded observations on many nights and curtailed observations on two nights on which about 45 minutes of observations were recorded on each night.

The number of birds seen on individual nights varied greatly. On a majority of evenings no migrants were seen. The maximum number of birds seen on a single evening during spring of 1995, prior to construction, was 14. During the May 1995 observations a small number of birds $(\mathrm{N}=26)$ was observed. Migrants were noted on only about one-third of the nights of observation (5 of 14 nights). During 13.75 hours 26 migrants were seen, averaging 1.89 birds per hour. Despite the low overall rate of passage, on two nights rates there were 8 birds per hour and 14 birds per hour. These nights, May 7 and May 8 , account for about $85 \%$ of all birds seen during the study. This is similar to wavelike events reported in the ornithological literature that occur during migration season, where major migration occurs on only a very few evenings during the season. The flight of May 7-8 constitutes such a wave. It is interesting to note that on the evening of May 8, the night with the largest numbers of birds observed, the wind was light from the northwest. On May 7, winds were strong from the west, when another good flight occurred. With few nights of truly favorable winds (from the south), migrants were compelled to migrate when winds were unfavorable, from the west and northwest.

After construction of the turbines, far fewer migrants were observed during spring migration. In spring of 1997 during 14 hours of observations only 5 migrants were seen for a passage rate of 
only 0.36 birds per hour. This is only about one-fifth the number seen in the migration season prior to construction. The maximum number seen during a single night was 2 birds (Table 5.3).

During autumn migration 1996, only a few turbines were standing and none was operating. A total of 77 migrants was observed for a total of 4.55 birds per hour. The maximum number counted was 8 and 9 birds per hour for ceilometer observations and 10 birds per hour via moon watching (Table 5.4). After construction of the turbines, passage rate dropped to only 0.14 birds per hour representing a total of only 2 birds observed in the ceilometer beam during the entire autumn migration study (Tables 5.5 and 5.6).

Direction of spring migrants during 1995 was primarily to the east, with the mean direction being toward 80 degrees (Table 5.2). Two birds (7.7\% of the sample) were observed flying to the west. The remaining $92.3 \%$ were distributed within a narrow band between $45^{\circ}$ and $105^{\circ}$. The axis of migration (straight line direction between wintering ground and breeding ground) for spring migrating songbirds in the eastern United States is to the northeast. The mean direction of $80^{\circ}$ may be a bit to the east of the presumed axis of migration. No mean direction of migration could be calculated for 1997, post-construction because of the small sample size.

Prevailing west winds explain the fact that so many of the migrants observed were flying to the east and east-northeast. Birds like songbirds, capable of flying at airspeeds of only 15-25 mph cannot fly into or across winds in the $30+$ mile per hour range as was the case on the evening of May 7. All birds on this evening flew directly downwind. Even with light winds from the northwest, migrants primarily flew with the wind in an easterly direction. On evenings when winds were light, direction of flight was diverse.

A considerable variation in flight direction was also observed for autumn migrants. The mean direction of migration during 1996, prior to construction of the turbines, was nearly due south (Table 5.4) with an angular deviation of about 62 degrees. Most birds were heading to the southwest and realized a southerly direction, a result of prevailing westerly winds. Of the 67 birds observed with the ceilometer, none were observed to fly in circles or in a confused manner. All birds that passed through the ceilometer beam were flying a straight course. A mean direction of migration for birds passing during autumn 1997 was not computed because of the small sample size.

The difference in numbers of migrants seen in the pre-construction studies of autumn and spring migration reflects differences in numbers of birds aloft during those seasons. Southbound autumn migrants represent adults and recently fledged immature birds. Those headed north in spring represent what is left of both groups after two migration seasons and a winter season. The difference is mostly attributable to natural mortality of these types of birds. In addition, there is usually a great amount of variability in migration counts that could explain a portion of the difference.

A comparison of the passage rate observed for spring and autumn migration at Searsburg with passage rates observed at other localities is instructive. Passage rates at Searsburg were about the same as those reported in a study conducted on hilltops in northwestern Maine. The Maine 
study reported an average of 2.15 birds per hour, which is only slightly greater than the passage rate (1.80 birds per hour) found in the present study for the pre-construction migration season. During autumn in Maine, the rate of passage was similar to the rate of 4.55 birds per hour reported in this study.

Studies conducted in North Dakota (Avery et al. 1977) reported rates of about 1 to 18 birds per hour for an average of 5.3 birds per hour. This is about twice the rate found in the present study for spring and similar to the rate for autumn. Farther south in Georgia, Able and Gauthreaux (1975) reported passage rates averaging more than 50 birds per hour, which is more than 25 times greater than found in southern Vermont during spring and 10 times greater than in autumn. Even the highest hourly passage rates in southern Vermont were less than the lowest passage rates from Georgia. A range of 18-130 birds per hour was observed in Georgia, while during autumn the range was 21 to 503 birds per hour (Able and Gauthreaux 1975). In Louisiana, Gauthreaux (1969) and Able and Gauthreaux (1975) have reported autumn passage rates of more than 800 birds per hour. These migration passage rates are one to two orders of magnitude larger than the 1.89 and 4.55 birds per hour found in the present study for preconstruction observations. Thus, the numbers of birds seen in Vermont were far fewer than reported farther south using the same methodology.

Topographic features such as coastlines, rivers, and long, linear ridges are known to concentrate songbird migrants, which could make numbers of birds per hour greater at more northerly sites. There are few topographic features near the Searsburg site that act to concentrate migrants. A study in central New York near Albany showed that the Hudson River was a "leading line" for migrants when winds were strong from the west during autumn migration (Bingman et al. 1982). Ceilometer passage rates in this study (and unpublished data from these authors) were much greater than those reported from southern Vermont (this study). Passage rates of greater than 10 birds per hour are normal from the Hudson Valley near Albany and the surrounding area. Greater rates of passage, often exceeding 30-40 birds per hour were not uncommon.

Although no ceilometer data are available, it is likely that the passage rates are much lower than those in coastal areas of New England. This assessment is based on personal observations in coastal New York and Cape May, New Jersey. It is also based on radar studies conducted along the coast of Massachusetts (Nisbet 1963) and the Canadian maritime provinces (Richardson 1971). A regression technique developed by Able and Gauthreaux (1975) describing the relationship between numbers seen on radar and ceilometer yields insight as to how many birds would be seen on radar in Vermont. This compared with coastal radar studies of migration by Nisbet and his colleagues shows that the density of migrants over Vermont is much lower than along the Massachusetts coast. The reason for this is because inland migration occurs over a very wide area and is diffuse, whereas birds concentrate along the coast because they are reluctant to fly out over the Atlantic Ocean.

At the Searsburg site, there are no rivers, lakes, or ocean coastlines, or ridges to act as leading lines, concentrating large numbers of birds into a small area. Instead, the landscape is dominated by hills and valleys that meander in directions that are seldom oriented in an appropriate direction for migration. The data collected in this study do not document any concentrating 
effect at the study site. The migration passage rate from this study of just less than 2 birds observed per hour in spring (pre-construction) and 4.55 birds per hour (pre-construction) indicates that there is a diffuse, broad-front migration that is most likely similar to the rate over hundreds or thousands of square miles of this portion of New England.

Before closing this section it is important to explore what is known about the altitude of nocturnal migration and bias inherent in the method used in this study. Ceilometers are biased to low altitude migrants, much lower than birds are detectable via radar. They are most effective for detecting birds below 1,500 feet so that birds above 2,000 or 2,500 feet are rarely seen. The reason for this is because the ceilometer beam cannot illuminate sufficiently birds that are more than 2,500 feet or more above the ground. Also, small birds are difficult to see at altitudes of more than 1,000 feet. It is possible that the actual passage rate of migrants over the Searsburg site is greater than the rate found in this study because of ceilometer bias. However, if birds are flying at altitudes beyond the range of the ceilometer, they will not be impacted by turbines.

It should be remembered that ceilometer bias is inherent in all studies using this method. Therefore, the results of ceilometer studies conducted in different parts of the world remain comparable (having the same bias), giving a relative estimation of the amount of migration that occurs at low altitudes. Because songbird migration at night proceeds mostly between 300 and 2,000 feet (Able 1970), ceilometers detect a good proportion of migrants that are aloft.

Another potential source of variance in this study that was not addressed was that of weather effects on migrants, specifically number of migrants aloft on a given night. The study was not designed to measure this effect, although weather can influence birds in a manner that increases risk of collision with towers. If carcasses of nocturnal songbird migrants begin to be found in appreciable numbers beneath wind turbines, more detailed study will be needed, especially regarding weather effects.

\section{Conclusions}

Although we do not know a great deal about the impacts of wind turbines on songbirds migrating at night at specific sites, we do know a considerable amount about migratory behavior that will help us determine the potential for impacts or risk to migrants. In addition, we are quickly gaining site specific information, as gathered in this study, that will help us make informed decisions as to relative risk at proposed wind energy sites. Studies like the present one are important not only for the project proposed for Searsburg, but also for siting of wind projects in other portions of Vermont, interior New England, and elsewhere.

It is unlikely that the Green Mountain Power wind energy project proposed for Searsburg, Vermont, will cause undue impact on populations of nocturnally migrating songbirds. This statement is based on the fact that the migration passage rate found in this study is low compared to other locations and on what has been established in many other studies regarding the altitude of migration. 
The density of night migrating songbirds over the Searsburg site is lower than reported in virtually all previous ceilometer studies. Migrants flying over southern Vermont, and probably over most of inland New England, are dispersed over a very wide area. They are not concentrated, at least at Searsburg, where they could be impacted adversely by towers.

Just as important, migrants usually fly at altitudes that are well above the height of the wind turbines proposed for Searsburg, except during takeoff and landing. Considered in light of the scarcity of migrants observed at Searsburg, this means that only a small number of birds could potentially be impacted and only during a small portion of a night's flight. It is also interesting that fewer migrants were observed over the wind power facility after construction than before construction. This may indicate that songbirds avoid turbines. Very few migrants, therefore, are likely to be at risk from this project. 


\section{Table 5.1. Representative Neotropical and Non-Neotropical Songbirds that Probably Migrate at Night Through the Searsburg, Vermont, Wind Power Facility During Spring and Autumn.}

\begin{tabular}{ll} 
Neotropical Species & Non-Neotropical Species \\
\hline Chimney Swift & Brown Creeper \\
Eastern Pewee & Red-breasted Nuthatch \\
Least Flycatcher & Eastern Phoebe \\
Alder Flycatcher & Winter Wren \\
Yellow-bellied Flycatcher & House Wren \\
Olive-sided Flycatcher & Golden-crowned Kinglet \\
Blue-gray Gnatcatcher & Ruby-crowned Kinglet* \\
Veery & Hermit Thrush* \\
Swainson's Thrush & American Robin \\
Red-eyed Vireo & Solitary Vireo* \\
Gray Catbird & Brown Thrasher \\
Chestnut-sided Warbler & Pine Warbler \\
Canada Warbler & Palm Warbler* \\
Blackpoll Warbler & Yellow-rumped Warbler* \\
Bobolink & Slate-colored Junco \\
Northern Oriole & Rufous-sided Towhee \\
Scarlet Tanager & White-throated Sparrow \\
Indigo Bunting & Purple Finch \\
Rose-breasted Grosbeak & Song Sparrow
\end{tabular}

*Some individuals of these species, especially those with western populations, migrate to and from the Neotropics and some, migrate at times during daylight hours. Neotropical migrants are considered to be species in which more than $80 \%$ of the entire population migrates south of the US-Mexico border (see Kerlinger 1995c for details). 
Table 5.2. Summary of Dates, Weather, and Numbers of Migrating Songbirds Observed via Ceilometer Observations at the Searsburg, Vermont, Windpower Development Area During Spring 1995.

An asterisk indicates that moon watching was used.

Date Time (EDT) Wind (mph) Cloud Cover Number of Birds Direction

\begin{tabular}{lllrrl}
\hline May 4 & $9: 15$ & W 5-10 & $100 \%$ & 2 & E \\
May 6 & $9: 00$ & W 35+ & $0 \%$ & 0 & n/a \\
May 7 & $9: 00$ & W 30+ & $0 \%$ & 8 & E \\
May 8 & $9: 15$ & NW 10-15 & $0 \%$ & 14 & E/NE \\
May 9* & $9: 00$ & W 2+ & $0 \%$ & 0 & n/a \\
May 13 & $9: 10$ & none & $50 \%$ & 1 & ENE \\
May 15 & $9: 10$ & NW 25-30 & $100 \%$ & 0 & n/a \\
May 16 & $9: 10$ & SE 5 & $100 \%$ & 1 & ENE \\
May 18 & $8: 40$ & W 20-25 & $100 \%$ (rain started) & 0 & n/a \\
May 20 & $9: 15$ & SW 5-10 & $0 \%$ & 0 & n/a \\
May 21 & $9: 00$ & SW-W 10-15+ & $50 \%$ & 0 & n/a \\
May 22 & $9: 05$ & W 10-15 & $10 \%$ & 0 & n/a \\
May 23 & $9: 10$ & SW 15-20 & $75 \%$ & 0 & $\mathrm{n} / \mathrm{a}$ \\
May 25 & $9: 15$ & none & $75+\%$ & 0 & $\mathrm{n} / \mathrm{a}$ \\
\hline
\end{tabular}

Mean Flight Direction - Just North of East - $80^{\circ} *$

Calculated arithmetically from a sample of 24 birds based on range of directions $\left(45-105^{\circ}\right)$, without two west bound birds. 
Table 5.3. Summary of Dates, Weather, and Numbers of Migrating Songbirds Observed via Ceilometer Observations at the Searsburg, Vermont, Windpower Development Area During Spring 1997.

An asterisk beside the date indicates that moon-watching was used.

Date Time (EDT) Wind (mph) Cloud Cover Number of Birds Direction

\begin{tabular}{lllrll}
\hline May 1 & n/a & \multicolumn{2}{l}{ Thunderstorms } & No Survey & \\
May 4 & $8: 50$ & NW 0-5 & $0 \%$ & 0 & $\mathrm{n} / \mathrm{a}$ \\
May 5 & $9: 00$ & N-NW 0-5 & $10 \%$ & 0 & $\mathrm{n} / \mathrm{a}$ \\
May 8 & $9: 00$ & NW 5-10 & $18 \%$ & 0 & $\mathrm{n} / \mathrm{a}$ \\
May 11 & $9: 10$ & NW 12-15 & $5 \%$ & 0 & $\mathrm{n} / \mathrm{a}$ \\
May 14 & $9: 05$ & W 10 & $100 \%$ & 1 & $\mathrm{~S}$ \\
May 16 & $9: 15$ & SW 5-10 & $75 \%$ & 1 & $\mathrm{E}$ \\
May 17 & $9: 15$ & NNW 10-15 & $85 \%$ & 2 & $\mathrm{NNW}$ \\
May 19 & $9: 05$ & NW 10-25 & $100 \%$ & 0 & $\mathrm{n} / \mathrm{a}$ \\
May 20* & $9: 00$ & N 10-20 & $5 \%$ & 0 & $\mathrm{n} / \mathrm{a}$ \\
May 24* & $9: 00$ & NW 10-15 & $20 \%$ & 0 & $\mathrm{E}$ \\
May 25* & $9: 00$ & NW 5-10 & $30 \%$ & 1 & $\mathrm{n} / \mathrm{a}$ \\
May 27 & $9: 15$ & NW 5-10 & $5 \%$ & 0 & $\mathrm{n} / \mathrm{a}$ \\
May 28 & $9: 10$ & W 5-15 & $0 \%$ & 0 & $\mathrm{n} / \mathrm{a}$ \\
May 31 & $9: 05$ & NW 15-20 & $50 \%$ & 0 & \\
\end{tabular}


Table 5.4. Summary of Dates, Weather, and Numbers of Migrating Songbirds Observed via Ceilometer Observations at the Searsburg, Vermont, Wind Power Development Area During Autumn 1996.

An asterisk beside the date indicates that moon watching was used.

Date Time (EDT) Wind (mph) Cloud Cover Number of Birds Direction

$\begin{array}{lllrrl}\text { Aug } 26 & 9: 05 & \text { SW 0-8 } & 50 \% & 0 & \text { n/a } \\ \text { Sept 5 } & 8: 45 & \text { SE 5 } & 10 \% & 2 & \text { n/a } \\ \text { Sept 6 } & 8: 30 & \text { SSW 7 } & 1 \% & 5 & \text { SSW } \\ \text { Sept 7 } & 9: 00 & \text { NE 12 } & 1 \% & 5 & \text { SW } \\ \text { Sept 10 } & 8: 30 & \text { N 5-15 } & 20 \% & 4 & \text { SW } \\ \text { Sept 14 } & 8: 30 & \text { NW 5 } & 30 \% & 5 & \text { SSE } \\ \text { Sept 19 } & 8: 15 & \text { N 15-20 } & 1 \% & 6 & \text { SE } \\ \text { Sept 21 } & 8: 30 & \text { W 5-10 } & 15 \% & 5 & \text { SW } \\ \text { Sept 26 } & 7: 50 & \text { NE 0-10 } & 1 \% & 4 & \text { E } \\ \text { Sept 26* } & 9: 00 & \text { NE 0-10 } & 1 \% & 10 & \text { SW } \\ \text { Sept 29 } & 8: 00 & \text { NW 10-20 } & 1 \% & 5 & \text { SE } \\ \text { Sept 30 } & 7: 45 & \text { NW 20-25 } & 1 \% & 4 & \text { SE } \\ \text { Oct 11 } & 7: 00 & \text { NW 5-10 } & 1 \% & 8 & \text { SE } \\ \text { Oct 12 } & 6: 45 & \text { NW 5-10 } & 65 \% & 5 & \text { S }\end{array}$

$\underline{\text { Mean Flight Direction }-182^{\circ}}$

Calculated arithmetically from a sample of 62 birds. 
Table 5.5. Summary of Dates, Weather, and Numbers of Migrating Songbirds Observed via Ceilometer Observations at the Searsburg, Vermont, Wind Power Development Area During Autumn 1997.

An asterisk beside the date indicates that moon-watching was used.

Date Time (EDT) Wind (mph) Cloud Cover Number of Birds Direction

$\begin{array}{lrlrll}\text { Sept } 2 & 10: 05 & \text { W 5-7 } & 40 \% & 0 & \mathrm{n} / \mathrm{a} \\ \text { Sept } 9 & 8: 45 & \text { NE 0-3 } & 90 \% & 0 & \mathrm{n} / \mathrm{a} \\ \text { Sept 11 } & 8: 00 & \text { SW 5-7 } & 45 \% & 0 & \mathrm{n} / \mathrm{a} \\ \text { Sept } 17 & 7: 30 & \text { S 7-10 } & 30 \% & 0 & \mathrm{n} / \mathrm{a} \\ \text { Sept 18 } & 7: 30 & \text { SW 5-7 } & 45 \% & 0 & \mathrm{n} / \mathrm{a} \\ \text { Sept 21 } & 7: 20 & \text { NW 5 } & 15 \% & 0 & \mathrm{n} / \mathrm{a} \\ \text { Sept } 27 & 7: 00 & \text { N 5 } & 0 \% & 0 & \mathrm{n} / \mathrm{a} \\ \text { Oct 2 } & 7: 00 & \text { S 10 } & 0 \% & 0 & \mathrm{n} / \mathrm{a} \\ \text { Oct 7 } & 6: 50 & \text { N 0-3 } & 15 \% & 1 & \mathrm{SW} \\ \text { Oct 10 } & 7: 00 & \text { NE 5-7 } & 0 \% & 0 & \mathrm{n} / \mathrm{a} \\ \text { Oct 11 } & 7: 15 & \text { N 0-3 } & 0 \% & 1 & \mathrm{n} / \mathrm{a} \\ \text { Oct 18 } & 7: 00 & \text { NW 10 } & 20 \% & 1 & \mathrm{SE} \\ \text { Oct } 20 & 6: 45 & \text { N 10-15 } & 50 \% & 0 & \mathrm{n} / \mathrm{a}\end{array}$

Table 5.6. Comparison of Numbers of Migrants and Hourly Rates of Migration Before (Spring 1995 and Autumn 1996) and After (Spring 1997 and Autumn 1997) the Construction of the Searsburg, Vermont Wind Power Facility.

Spring

$\underline{\text { Autumn }}$

$\begin{array}{lll}\text { Before } & 26-1.89 \text { per hour } & 77-4.55 \text { per hour } \\ \text { After } & 5-0.36 \text { per hour } & 2-0.14 \text { per hour }\end{array}$




\section{Chapter 6. Hawk Migration}

\section{Introduction}

There are two reasons for concern about migrating raptors at new wind power facilities. First, hawks, more than any other type of birds, are susceptible to collisions with wind turbines. Second, migrating hawks sometimes concentrate in large numbers during autumn and spring presenting the potential for higher risk at these locations. Concentration sites for migrating hawks are usually on ridges and coastlines, and because these areas often have the potential for wind power development, the potential for risk is evident. Very few studies have examined interactions between migrants and wind turbines (Colson \& Associates 1995) and almost no studies have examined the impact of wind turbines on the behavior of migrating hawks. A review of such work in the eastern United States reveals that the reason for this is because there are so few wind power facilities now operating in this area and because there are few turbines in these facilities. Most studies of migrants in the northeastern United States have been confined to studies done prior to permitting and construction to determine the probability of interactions between turbines and birds (Cooper et al. 1995, Northrop, Devine, and Tarbell 1995a, 1995b).

As a first attempt to examine interactions between operating wind turbines and migrating hawks, studies of migrating hawks have been conducted at the Searsburg, Vermont, wind power facility. This study consists of hawk migration counts as well as before and after behavioral observations of hawks migrating through or near the wind power facility. This chapter documents the numbers of hawks migrating at this wind power site and compares the magnitude of migration there with other locations, both in Vermont and elsewhere in the eastern United States. In addition, the behavior of migrating hawks before and after construction of the wind turbines will permit an examination of how the behavior of migrating hawks is influenced by new wind turbines. This report focuses on documenting the numbers of hawks migrating at the Searsburg wind power facility and the behavior of migrating hawks at the site before and after the turbines were constructed.

\section{Methods}

During portions of September, October, and early November, 1993, 1994, 1996, and 1997, a study of migrating hawks was conducted at the Searsburg Wind Power Facility, Vermont, wind energy station. The actual observation site was about $50 \mathrm{~m}$ from the eastern border of the land on which the turbines are located. It is in a cemetery at the junction of state Route 8 and Sleepy Hollow Road. Observations were made by a lone observer from the center of the cemetery during all four autumns (dates of observations are in Table 6.1). The observation site provides the best view of the entire area where the turbines were installed as well as the area surrounding the construction site. Observations were made using standard power birding binoculars between 10:00 a.m. and 14:00 p.m. EST. Most observations were made under clear skies with winds from a northerly or westerly direction, often shortly after the passage of a cold front. Such conditions are known to be associated with the movement of large numbers of hawks, often at 
low altitudes, at most migration count sites in the northeastern United States and eastern Canada (Kerlinger 1989). By selecting the optimal days for migration, a maximum number of raptors was seen. Although this might bias the data set, it provides the greatest sample sizes and, potentially, "worst case" scenarios for turbine impacts. For example, the best days for migration increase the numbers of birds seen, and therefore, the potential number of interactions between turbines and birds. If the worst days for migration were selected (southerly winds and, or rainy days), the bias would have been toward smaller numbers of birds and a "best case" scenario for interactions (i. e., very few interactions and low risk). The methodology used was a conservative means of examining the questions posed regarding interactions between migrating birds and wind turbines.

Data recorded for each individual or flock that passed included: species, altitude, location over the hillside, the type of flight used, and the direction of flight. Altitude was determined by estimating the birds' height above ground to the nearest 50 feet, or for birds lower than 50 feet to the nearest 10 feet. For location over the ground, the landscape was divided into four sectors: sector A was the area from the top of the hill to the west of Route 8 down to Route 8, sector B was the area from Route 8 to the base of the turbine hill, sector $C$ was the west side of the turbine hill up the hillside nearly to the turbines, and sector D was the hilltop where the turbines were located. Flight direction was simply the direction a bird realized (its track) over the ground in one of eight cardinal directions (N, NE, E, SE, S, SW, W, NW). In addition to flight behavior, local weather data were collected each hour. Weather data included wind speed and direction, percentage cloud cover, temperature, and precipitation. Each day, the synoptic weather conditions were noted as well (i.e., passage of cold fronts and location of high pressure areas). After construction of the turbines, the observer noted whether the turbines were revolving or not during the observation period.

Data from 1993 and 1994 were pooled because during each of these years only one-half a season of observations was collected. Dates of observations during these years were complementary with no overlap in calendar dates for the two periods.

\section{Results}

The total number of raptors observed during each autumn varied greatly with 1993 -1994 and 1996 having larger hawk counts than 1997. When the number of hawks per hour is considered the 1993-1994 count and 1996 count are virtually identical (Tables 6.1 and 6.2). The number of hawks seen in 1997 after the turbines were operational is only a small portion of those seen before construction, although the dates, duration, and methods used were virtually identical. The slightly longer observation period in 1993-1994 accounted for 14.8 more hours of observations in that year than in 1996 and 1997. The difference between the pre-construction counts and postconstruction counts was impressive, constituting about a $90 \%$ reduction in numbers of hawks counted.

In the three complete seasons of counting 13 species of raptors were noted (Table 6.2). Twelve species were counted during 1993-1994 and 1996, but only six species were counted in 1997. 
The most numerous species were the Red-tailed Hawk (31.6\% of total hawks seen) followed by Sharp-shinned Hawk (27.2\%) and Broad-winged Hawk (18.9\%) in that order. These species accounted for slightly more than three-quarters (77.8\%) of all hawks observed in all years. The next most common species were Turkey Vulture, American Kestrel, Northern Harrier, Osprey, Cooper's Hawk, and Red-shouldered Hawk. The Federally Endangered and Threatened species seen during the study period included 3 Bald Eagles in 1993-4, 2 Bald Eagles seen in 1996, and 1 Peregrine Falcon seen in 1993-1994. Another such species, Ospreys were observed in all three observation years.

The altitude of migration averaged between 315 and 644 feet (97-198 m) above ground level for the three most numerous species (Sharp-shinned Hawk, Broad-winged Hawk, and Red-tailed Hawk) and for all other hawks combined (Table 6.3) during 1996. Some individuals were observed at well above 1,000 (308 m) and even 2,000 (616 m) feet above the ground. The variation around these means, however, was large. Standard deviations ranged from 283 to 377 (87-116 m) feet. Broad-winged Hawks flew highest of the hawks and averaged nearly 300 feet (92 $\mathrm{m})$ higher than the other species. Examining only those birds that passed over the sector on which turbines were being erected, the mean altitudes were about the same as over other sectors (Table 6.3). Differences between overall means and means for the turbine sector for each species were only in the 30-45 feet (9-14 m) range.

The percentage of each species that flew within the first 200 feet $(62 \mathrm{~m})$ of the ground, the stratum that is within the height of turbine towers, ranged from $44.0 \%$ for Sharp-shinned Hawks to only $3.6 \%$ for Broad-winged Hawks. The percentage for Sharp-shinned Hawks was considerably higher than for the other species. This means that nearly $60 \%$ of the Sharp-shinned Hawks flew above the height of turbines and about $96 \%, 73 \%$, and $68 \%$ of all Broad-winged Hawks, Red-tailed Hawks, and other species flew above the height of turbines (Table 6.3).

The altitude of migration after construction of the turbines was lower than prior to construction (Tables 6.3 and 6.4). However, sample sizes in 1997 were so low as to question whether the averages computed were meaningful. It is interesting to note that a large portion of the birds were observed at below 200 feet (62 m; Table 6.4).

Slightly more than one-half of all hawks were observed flying over Sector D in 1996 (before construction), the sector in which turbines were eventually be erected (Table 6.5). Between $50.0 \%$ and $56.7 \%$ of all species were seen over this elongated hill. A smaller, though substantial proportion of Sharp-shinned and Broad-winged hawks flew over Sector A, ranging from 14.5\% for Red-tailed Hawks to almost one-third of all Broad-winged Hawks. For Red-tailed Hawks and other hawks, Sector C was used by substantial numbers of individuals. Sector B was used least often of all sectors by most species. The percentages in this sector ranged from only $2.1 \%$ for Sharp-shinned Hawks to 10.7\% for Broad-winged Hawks.

Following construction of the turbines and once they were operating it appeared that few if any hawks migrate through the airspace the turbines occupy (Table 6.6). Though there were few birds that were counted over all the sectors during 1997, Sector D in which turbines were 
situated had virtually no migration activity. It appeared as though migrating hawks avoided this sector and the airspace above it.

Examining the altitude of those hawks migrating over the turbine sector (D) prior to construction, the percentages that passed below 200 feet were 22.7\% for Sharp-shinned Hawks, 2.4\% for Broad-winged Hawks, 7.3\% for Red-tailed Hawks, and 17.7\% for all other species combined. For all hawks combined the percentage was only $13.3 \%$. This constitutes a low risk to migrants because so few use the airspace in which the turbines were eventually placed.

Flight direction of migrants varied little with the largest proportion of all species tracking to the southwest (Table 6.7). This percentage varied among species. Broad-winged Hawks exhibited southwesterly movement (92.9\%) more often than other species, whereas less than one-half of all Red-tailed Hawks moved to the southwest. Movement to the south was infrequent with Red-tails and other hawks moving in this direction more than other species. Very few individuals $(<5 \%)$ of any species were observed moving to the southeast (Table 6.7). Average flight directions were not calculated for the 1997 hawk migration season because there were so few migrants. Small sample sizes precluded statistical analyses.

\section{Discussion}

Hawk migration at Searsburg is similar to hawk migration throughout much of the northeastern United States. It is, however, quite different from those few migration sites where hawks concentrate in large numbers. Flight behavior at Searsburg is characterized by small numbers of birds, spread over a broad front at relatively high altitudes. This has been termed "broad front" migration, as opposed to migration that is funneled along ridges or along a coastline (see Kerlinger 1989 for discussion of broad front vs leading line migration). At Searsburg, where hawks depend on thermals and wind generated updrafts off hills for lift, they fly at several hundred feet above the ground and they are spread over the landscape.

At migration concentration points, vast numbers of hawks migrate and often fly at very low altitudes. At these times they often fly below 100 feet, and use ridge lift (wind deflected upwards of ridges) or wind deflected off trees and dunes. This type of migration is very concentrated and not broad front. Also, at Searsburg there are no major topographic leading lines as there are at concentration sites. At Searsburg, hawks move over most of the landscape and do not have long leading lines to follow. Behavioral information generated in this study is consistent with broad-front migration.

The numbers of hawks counted during the autumn 1996 migration study at Searsburg, Vermont, was similar to the numbers reported in two previous autumn studies (Martin 1993, 1994) conducted at that site. The slightly greater observation time in 1996 over 1993 and 1994 realized a slightly greater number of migrating hawks. However, when the number of hawks seen was standardized for the number of hours of observations (divided by the number of hours of observations), the number of hawks seen in 1996 was between the numbers reported for 1993 and 1994 (Table 6.2). 
When the numbers of hawks seen at Searsburg, Vermont, is compared with the numbers counted at well-known observation sites (Table 6.8) it is obvious that the numbers at Searsburg do not represent a significant concentration. Searsburg counts are only about $1 \%$ of the counts from Cape May, New Jersey, and only about $2 \%$ of those from Hawk Mountain, Pennsylvania. These latter sites are the premier autumn hawk migration observation sites in the eastern United States. The former is located along a coastline at the end of a peninsula and the latter is situated on a long, linear ridge. Both of these topographic situations act to "funnel" hawks to the hawk migration count sites. At Cape May the number of hawks, when corrected for hours of observation, is more than 50 hawks per hour and at Hawk Mountain the number is more than 30 birds per hour. These per hour counts are 6 to 10 times greater than those found at Searsburg in this and previous studies.

Even when comparing the Searsburg hawk migration counts (prior to construction) with migration counts taken in other parts of Vermont show that Searsburg does not have a significant migration (Table 6.8). The numbers reported from Searsburg in 1993-1994 and 1996, prior to construction, are slightly lower than those reported from four other hawk migration counts done in Vermont in recent years.

It should be remembered that if a full season of observation were made at Searsburg (longer season, every day, and more hours on each day), as is done at most large hawk migration sites, the per hour count would be considerably less than reported here. Even so, the hourly hawk counts are somewhat less than other sites from Vermont. More observations would have added to the total number of hawks, but also would have added days with poor conditions for migration, as well as days that are earlier and later in the season when fewer birds migrate, and hours earlier and later in the day when fewer birds migrate. Thus, the Searsburg counts are but a small fraction of the counts at recognized locations and, thus, Searsburg is insignificant in the larger picture of hawk migration.

It is likely that more birds pass over the Searsburg site than was indicated by the counts reported in this and previous studies (Martin 1993, 1994). Ground based counts have frequently been shown to miss a significant portion of migrants passing over a site because direct visual observations simply cannot monitor high altitude migration (Kerlinger 1989, 1995c). Using radar, Kerlinger (see review and references in Kerlinger 1989) and others have shown that migrants in the northeastern United States and elsewhere regularly pass at thousands of feet above the ground. At these times they are often almost invisible to all but the most diligent and gifted counter using naked eyes and binoculars. However, these birds are irrelevant to this study because they will in no way be influenced by wind turbines. They are too high to be influenced or to be impacted by turbines. For completeness, this fact is included in this report.

The altitude of hawks migrating through the Searsburg wind power facility shows that a majority of individuals passes at altitudes well above the turbines' blades, at least during the year prior to construction. Few individuals flew below the 200-foot height of turbines and a small percentage of all migrants flew below 200 feet within Sector D, in which wind turbines will be erected. What this means is that the risk for impacting individuals of all species is low, with Sharp- 
shinned Hawks being at greatest risk. The maximum number of individuals that could be impacted is a function of the percentage that fly through Sector D at altitudes below 200 feet.

The altitude of migration at Searsburg in the year prior to construction and operation of the turbines was about the same as has been found in other studies of hawk migration away from ridges and coastlines (Kerlinger 1989). In addition, the variability of migration altitude was about the same, with the large variability being a function of the fact that soaring migrants constantly change altitude as they use updrafts to gain altitude and as they lose altitude while gliding between updrafts. Despite this variability, much of migration at Searsburg was above the height of the turbine blades.

The altitude of hawks migrating through the Searsburg wind power facility shows that a majority of individuals passed at altitudes well below the height to which turbine blades extend. This is very different from the results found in 1996. In fact, the results from the 1997 field season contradict the earlier report. The fact that birds flew so low might suggest that they would be vulnerable to turbine impacts. However, the numbers of birds involved are too small to make valid statistical comparisons.

Despite the fact that fewer migrants were seen in 1997 than in previous years, it is important to note that the same number of hours was spent in the field. Explanation of this difference may be explained by fewer birds migrating in the autumn of 1997 than in 1996, although the magnitude of the difference is not reasonably explained by a much smaller number of hawks migrating. Two better explanations may be invoked. In the first, weather was such that migration may have flown over at very high altitudes. Because wind speeds were not as strong as in 1996, birds could have flown using the benefits of thermals that extended to higher altitudes. When winds are light thermals often are stronger and birds fly higher.

The other explanation of the smaller number of migrants counted is the presence of wind turbines and avoidance behavior on the part of migrants. Migrants flying southward may never have seen turbines before and simply flown around them. It may be that these birds avoid novel structures like the newly erected turbines. In doing so, many could have flown to the east side of the hilltop or to the west of the hawk count location. The turbines are visible from several miles away, giving birds time to deviate well before arriving at the turbines. This would take them out of the visual field of the observer. This author has observed thousands hawk migrants flying through the wind turbine fields at Tarifa in Spain, near the Straits of Gibraltar. These birds simply fly around the ends of turbine strings, sometimes disappearing behind mountainous hills.

There is some evidence that the birds do avoid the hilltop on which turbines are situated. The percentage of birds seen over Sector D - the hilltop with the turbines - in 1997 was only $2.6 \%$, down from a much higher percentage in $1996(>50 \%)$. This suggests that birds were avoiding Sector D, flying farther to the west where they were observed in greater percentages over Sector $\mathrm{A}$ and $\mathrm{B}$ than in previous years, or out of visual range. Birds that flew around Sector D to the east would have been difficult or impossible to see from the observation site. 
The fact that so few individuals were seen flying over Sector D, the turbine sector, negates the potential for impacts, even for birds flying at low altitudes. This is because those flying at altitudes within the range of turbine blades were not flying near the turbines. Again, there is a suggestion that birds avoid the turbine area by flying around it to the east and west. No interactions of birds flying in close proximity to turbines were observed.

Several conclusions can be drawn from the 1997 field season data set and analysis. First, there is no reason to believe that wind turbines negatively impact migrating hawks. Though there may be behavioral responses to the turbines in the form of avoidance (flying around the turbines) by birds, there is, at this time, no evidence that they collide with turbines during their south bound migration.

A second conclusion made from the data reported herein is that the 1997 hawk migration count from Searsburg is representative of an atypical year of hawk migration. The reduction in numbers of hawks counted was extraordinary. This researcher feels that another season of hawk migration counts and behavioral data would be helpful to planners in that it would permit them to eliminate the possibility that the low count of 1997 was an anomaly. If larger numbers of hawks do fly through the area in subsequent years, another field season of data taking would provide better insight into the behavior of hawks when confronted by turbines during their southbound migration. Another field season would provide the potential to draw more robust conclusions regarding risk, or lack thereof, to migrating hawks at wind power developments. 
Table 6.1. Dates of Observations of Hawk Migration Studies at the Searsburg, Vermont, Wind Power Facility.

\begin{tabular}{rrrrr} 
Year & Starting Date & Ending Date & Species & Total \\
\hline 1993 & 1 September & 20 September & 10 & 145 \\
1994 & 20 September & 28 October & 12 & 380 \\
1996 & 11 September & 3 November & 12 & 430 \\
1997 & 17 September & 4 November & 6 & 39 \\
\hline
\end{tabular}




\section{Table 6.2. Counts of Migrating Hawks by Species Observed at the Searsburg, Vermont Wind Power Facility, 1993-1997.}

For purposes of comparison, 1993 and 1994 data were pooled because observations in those years included complementary dates and together are equivalent to the duration and seasonal timing of hawk counts from 1996 and 1997.

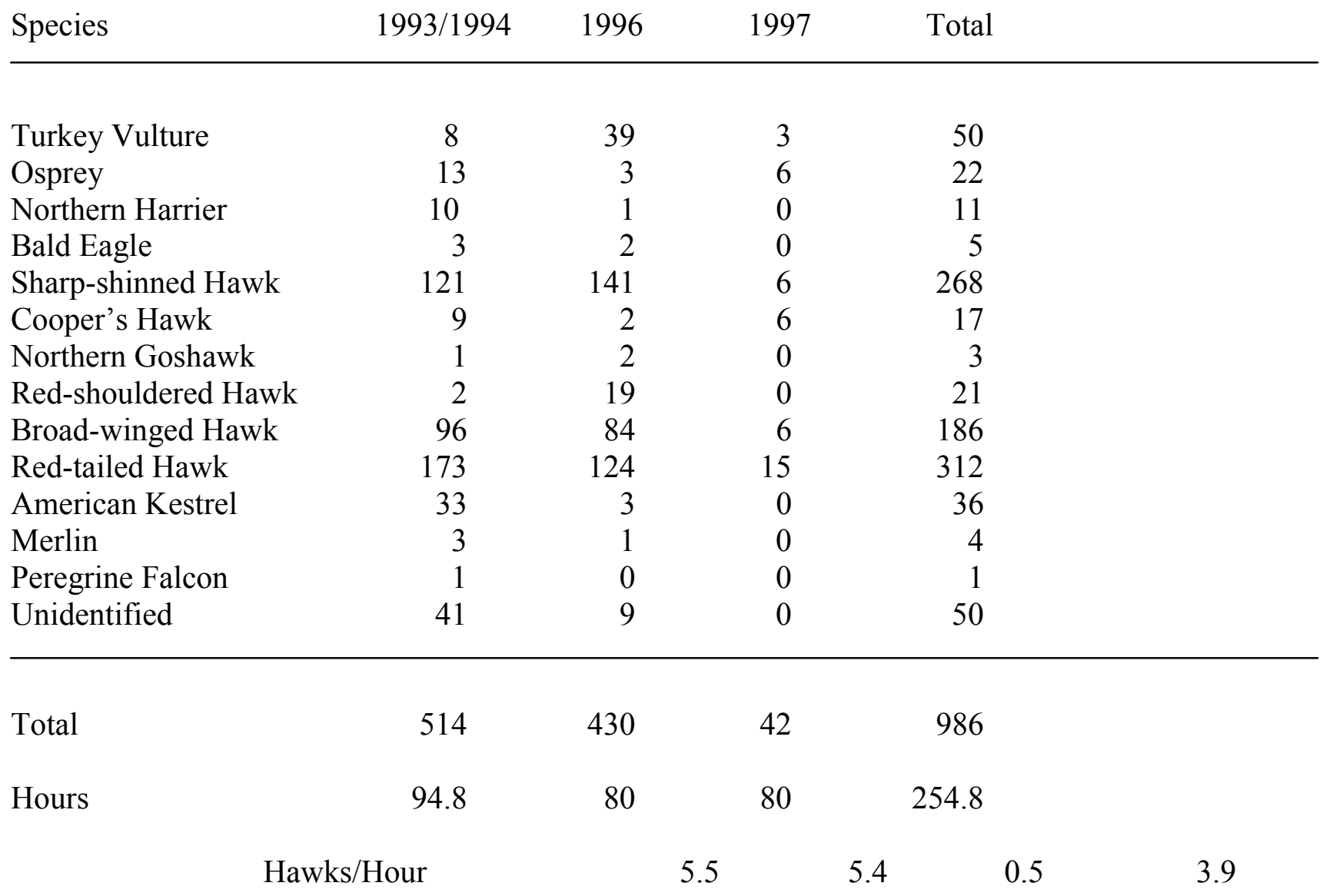




\section{Table 6.3. Summary of Migration Altitude for Autumn 1996 Hawk Migration at Searsburg, Vermont.}

Other species include Bald Eagles, Osprey, Northern Harrier, Cooper's Hawk, Northern Goshawk, Red-shouldered Hawks, American Kestrels, Merlins, and several unidentified hawks (see Table 6.2 for numbers of each seen). Altitude is divided into all sectors through which hawks were observed and the sector in which the turbines were being installed.

\begin{tabular}{|c|c|c|c|c|c|c|c|}
\hline \multirow[b]{2}{*}{ Species } & \multirow[b]{2}{*}{$\begin{array}{c}\text { Sample } \\
\text { Size }\end{array}$} & \multicolumn{3}{|c|}{$\underline{\text { All Sectors }}$} & \multicolumn{2}{|c|}{$\underline{\text { Turbine Sector }}$} & \multirow[b]{2}{*}{$\begin{array}{l}\text { Standard } \\
\text { Deviatior }\end{array}$} \\
\hline & & Mean & $\begin{array}{l}\text { Standard } \\
\text { Deviation }\end{array}$ & $<200$ feet & $\begin{array}{l}\text { Sample } \\
\text { Size }\end{array}$ & Mean & \\
\hline Sharp-shinned Hawk & 141 & 315 & 300 & $44.0 \%$ & 80 & 347 & 319 \\
\hline Broad-winged Hawk & 84 & 644 & 377 & $3.6 \%$ & 43 & 612 & 324 \\
\hline Red-tailed Hawk & 124 & 367 & 283 & $27.4 \%$ & 62 & 332 & 208 \\
\hline Other Hawks & 81 & 366 & 320 & $32.1 \%$ & 45 & 343 & 283 \\
\hline
\end{tabular}




\section{Table 6.4. Summary of Migration Altitude for Autumn 1997 Hawk Migration at Searsburg, Vermont.}

Other species include Turkey Vulture, Osprey, Cooper's Hawk, and Broad-winged Hawk (see Table 6.2 for numbers of each species seen).

\section{$\underline{\text { Altitude }}$}

Species

$\begin{array}{ccc}\text { Sample } & \text { Mean } & \begin{array}{c}\text { Standard } \\ \text { Deviation }\end{array}\end{array}$

Sharp-shinned Hawk

6

$70^{\prime}$

$46^{\prime}$

$100 \%$

Red-tailed Hawk

15

153'

$128^{\prime}$

$66.7 \%$

Other Hawks

21

$209^{\prime}$

249'

$64.7 \%$

All Hawks

42

$164^{\prime}$

$187^{\prime}$

$71.1 \%$ 


\section{Table 6.5. Summary of Migrating Hawks Seen in the Four Sectors During Autumn at Searsburg, Vermont in 1996.}

See Methods section for a description of sectors. Sector D is the sector in which turbines were being installed. Other hawks include Bald Eagles, Osprey, Northern Harrier, Cooper's Hawk, Northern Goshawk, Red-shouldered Hawks, American Kestrels, Merlins, and several unidentified hawks

Species Sample Size Sector A Sector B Sector C Sector D

$\begin{array}{lrrrrr}\text { Sharp-shinned Hawk } & 141 & 22.0 \% & 2.1 \% & 19.1 \% & 56.7 \% \\ \text { Broad-winged Hawk } & 84 & 32.1 \% & 10.7 \% & 6.0 \% & 51.2 \% \\ \text { Red-tailed Hawk } & 124 & 14.5 \% & 4.5 \% & 30.6 \% & 50.0 \% \\ \text { Other Hawks } & 81 & 18.8 \% & 8.2 \% & 20.0 \% & 52.9 \%\end{array}$




\section{Table 6.6. Summary of Migrating Hawks Seen in the Four Sectors During Autumn at Searsburg, Vermont 1997.}

See Methods section for a description of sectors. Sector D is the sector in which turbines were being installed. Other hawks include Osprey, Cooper's Hawk, and Broad-winged Hawk, and Turkey Vultures.

$\begin{array}{lllll}\text { Species } & \text { Sample Size } & \text { Sector A } & \text { Sector B Sector C } & \text { Sector D }\end{array}$

\begin{tabular}{lccccc}
\hline Sharp-shinned Hawk & 6 & $16.7 \%$ & $50.0 \%$ & $33.3 \%$ & $0.0 \%$ \\
Red-tailed Hawk & 15 & $33.3 \%$ & $53.3 \%$ & $13.3 \%$ & $0.0 \%$ \\
Other Hawks & 17 & $58.8 \%$ & $23.5 \%$ & $11.8 \%$ & $5.9 \%$ \\
All Hawks & 42 & $42.1 \%$ & $39.5 \%$ & $15.8 \%$ & $2.6 \%$ \\
& & & & \\
\hline
\end{tabular}




\section{Table 6.7. Flight Directions of Autumn Hawk Migrants at Searsburg, Vermont, 1996.}

Species included in the "Other Hawk" category are: Bald Eagles, Osprey, Northern Harrier, Cooper's Hawk, Northern Goshawk, Red-shouldered Hawks, American Kestrels, Merlins, and several unidentified hawks. Totals do not sum $100 \%$ because hawks flying in directions other than those listed in the table (distributed from west to east, inclusive) were too few in numbers to be included in the table.

Species Flight Direction

Sample SizeSoutheast South Southwest

\begin{tabular}{lcccc}
\hline Sharp-shinned Hawk & 141 & $2.1 \%$ & $7.1 \%$ & $73.8 \%$ \\
Broad-winged Hawk & 84 & $2.4 \%$ & $1.2 \%$ & $92.9 \%$ \\
Red-tailed Hawk & 124 & $4.8 \%$ & $18.5 \%$ & $58.9 \%$ \\
Other Hawks & 81 & $3.5 \%$ & $15.3 \%$ & $40.0 \%$ \\
\hline
\end{tabular}




\section{Table 6.8. Comparison of Hawk Migration at Searsburg, Vermont, Green Mountain Power Corporation Wind Energy Site with Counts at Well-Known Migration Concentration Sites.}

The numbers reported are approximations of average numbers of hawks counted at the sites over many years. The numbers given for Searsburg are actual counts conducted in 1993 and 1994 (pre-construction), 1996 (during construction), and 1997 (post-construction).

Site

Numbers of Hawks Per Autumn (hours) Hawks Per Hour

Searsburg, Vermont (1993)

Searsburg, Vermont (1994)

Searsburg, Vermont (1996)

Searsburg, Vermont (1997)

Cape May, New Jersey

Hawk Mountain, Pennsylvania

Lighthouse Point, Connecticut

Braddock Bay, New York

Other Vermont Sites

Putney

Pinnacle

Mount Philo

Paine Mountain
380 (63.5 hours)

145 (31.3 hours)

430 (80 hours)

42 (80 hours)

50,000 (900 hours)

25,000 (800 hours)

12,000 (525 hours)

75,000 (800 hours)

1,170 (85 hours)

3,400 (452 hours)

1,850 (51 hours)

295 (59 hours)
6.0

4.6

5.4

0.5

55.6

31.2

22.8

93.8

13.7

7.5

36.2

5.0 


\section{Chapter 7. Avian Fatality Study}

\section{Introduction}

The development of wind power in the northeastern United States is in its infancy. As projects are proposed, several questions relating to environmental issues are posed. The primary question is, "Do wind turbines kill birds, and, if so, how many?" There is a long history of birds flying into tall towers of various sorts (see Chapter 2), including wind turbines (Colson \& Associates 1995, Orloff and Flannery 1996, Winkelman 1995). However, because wind turbines are such a new development on the landscape, answering these questions is still not easy. We are learning that in most situations turbines kill few birds. Recent studies by Anderson (in press) in California, Winkelman $(1994,1995)$ in the Netherlands, Strickland (in press) in Minnesota, and Kerlinger and Curry (in progress) in Colorado are studies that are now being conducted or recently completed suggest that small numbers of birds are killed. In fact, there is only one site where the kills are considered egregious and that site is the Altamont in California, where nearly 5,400 turbines now stand. The actual numbers killed in the Altamont do not exceed one bird per turbine per year and rates of between 0.05 raptors per turbine per year (Orloff and Flannery 1992, 1996) and 0.019 raptors per turbine per year (Kerlinger and Curry 1998) have been reported.

From the Altamont case study a perception of wind turbines as machines that kill birds has grown. While it is true that turbines do kill small numbers of birds at most sites, determination of the potential for large kills should be a goal at sites that are proposed for wind power development. Studies of the number and type of birds that frequent an area may provide the best source of data for predicting risk attributable to windpower development at a given site. However, risk is species specific, as shown by Orloff and Flannery $(1992,1996)$ and others. Just as important is a monitoring program for wind power facilities that are on-line to determine if and, or how many birds are killed. This report summarizes results of the first study of avian fatality at a commercial wind power facility in the United States (excluding studies of test turbines) east of the Mississippi River. The number of kills, scavenging rate of kills, detectability (variability, interobserver reliability, and efficiency) at finding kills, and comments/suggestions for future study of this question are provided.

\section{Methods}

Three study methodologies are described below. The first is a simple method for determining whether or not birds are killed by the Searsburg turbines. The second is for determining if scavengers are removing carcasses of birds that may have been killed by turbines and the rate at which carcasses are removed. The third is a study of observer variability in ability to detect carcasses beneath wind turbines. The degree of variability relates to the efficiency of observers at finding carcasses and inter-observer reliability. Together these studies provide answers that permit projections or estimations of actual numbers of kills, if they occur. 
Fatality Searches. To determine whether birds were being killed by the turbines, searches for dead birds were undertaken between 30 June and 18 October (Table 7.1). A minimum of four turbines was searched during a search period, with the area beneath each turbine searched for 30 minutes. Each turbine was searched a minimum of 6 times (as called for by the design) during the study period, although some were surveyed up to 10 times. Searching was accomplished by systematically walking of the area beneath the turbines. The area of these searches varied slightly as a function of the area cleared around each turbine, because these areas were irregular in shape. The area searched ranged from a minimum of $15-20 \mathrm{~m}$ to the nearest forest to $40 \mathrm{~m}$. Searches beyond these areas were extremely difficult because of dense spruce, Viburnum, and other vegetation, although searches included the first few meters of forest. In addition to the systematic fatality searches that were part of this project, workers (Zond/Enron Windpower Corp.) were requested to report any fatalities to the author of this report.

Scavenging Rate Determination. Although the number of birds found beneath wind turbines provides an indication of fatalities associated with operating wind turbines, the numbers found may be a small subset of overall numbers killed (Orloff and Flannery 1992, Howell and DiDonato 1991). For example, scavengers such as raccoons, coyotes, cats, crows, and vultures routinely eat birds that have been killed by TV/radio antenna towers and glass windows (many of references cited in Literature section). Some of these organisms, and others, frequent areas where carcasses accumulate and are proficient at "cleaning" the area soon after the carcasses fall to the ground. Some of these scavengers can be seen "working" an area with regularity. Thus, they learn to forage where dead birds are likely to be found. This is true for wind turbines as well as other structures.

By determining the rate of scavenging (the rate at which dead birds disappear from the ground beneath turbines) a better projection/estimate of the actual number of birds killed can be determined. This rate can be approximated by placing carcasses of birds beneath the turbines and measuring the duration that they remain in place. The rate at which they disappear is the scavenging rate. A high rate, such as $90 \%$ per week, would mean that searching for dead birds would not reveal many birds if done at intervals of more than a few days. A low rate, such as $10 \%$ would mean that almost all of the birds would still be in place after a week. From these rates the actual number of birds that were killed could be estimated.

Turbines used for determining scavenging rate included turbine numbers $4,3,2$, and 1 in JuneJuly and turbine numbers $11,10,9$, and 8 in September-October. The 20 carcasses placed out on June 30 were searched on July 1 and 2, and subsequently on September 2. The 20 carcasses placed out on September 2 were searched for on September 9, September 17, September 27, and October 2. Birds used for this test and the detectability test described below included many of the species that nest on or near the Searsburg wind power facility (Table 7.2). These species were used because they provided a realistic or close resemblance to the size, shape, and color of the species that could potentially be killed by the revolving turbines. Birds were provided by the New Jersey Audubon Society's Cape May Bird Observatory and the Vermont Agency of Natural Resources. All met their demise as a result of colliding with windows, automobiles, or as a result of "predation" by house cats. 
Carcass Detectability - Observer Variability/Efficiency/Inter-observer Reliability. In addition to scavenging, observers vary in their ability to detect carcasses, which would need to be factored into estimation of actual fatality at a wind power facility or a tower. A perfect observer would not miss any carcasses. In reality, some birds will be missed because they may blend in with the background or be obscured by leaves, grass, etc. To determine observer efficiency and how much variability there can be among observers, twenty birds were placed beneath four turbines by two test observers (the author and a second person with professional field birding experience). On September 2, each of the observers placed 10 birds beneath two turbines in a quasi-random fashion. They used no predetermined pattern and threw the birds with their right hand over their left shoulder. They then mapped the birds on a piece of paper so that they could be used later for scavenging studies. The second observer then attempted to locate them using a 30 minute search period at each turbine; the same as used during the fatality searches. The same technique was used for these searches as for the regular carcass searches. Turbines used were 11, 10, 9, and 8 .

The percentage of birds found by an observer is the detectability rate. If 2 of 10 were found, the rate is $20 \%$. Thus, if 50 birds were actually killed by the turbine a detectability rate of $20 \%$ would result in 10 birds being found.

From the three studies described above, an actual kill rate can be projected/estimated. For example, if 20 birds were found under the turbines with scavenging rate of $25 \%$ per week and a detectability rate of $50 \%$ the following calculation would be used to determine the actual number of birds killed. Assume that search was conducted one week after the ground was cleared of all kills.

20 birds found $/ 50 \%$ detectability $=40$ birds actually present after 1 week

40 birds actually present $/ 75 \%$ remaining after scavenging $=53.3$ birds actually killed

By this method the number of birds found would be divided by the detectability to arrive at the actual numbers that were present. Then the numbers present would be divided by the difference between scavenging rate and $100 \%$.

\section{Results}

The following sections address each of the three topics covered in this report.

Fatality Searches. In a total of 21 search periods ( 1 search period equals four turbines searched) not one dead bird was located in the Searsburg wind power facility (Table 7.1). These observation periods were conducted on 15 different days and consisted of about 41 hours of search time. On some days two search periods were used. This represents a total of 82 searches conducted under individual turbines during four (five if August is included) months. (The number of search periods is more than the number called for in the original proposal $(\mathrm{N}=6)$ that was approved by NREL. The extra searches were done after consulting with other biologists and realizing that more were needed to insure that the observations were reliable and valid indicators of actual fatality rates. In addition, no dead birds were found by workers at the wind power plant 
since it went on-line in spring 1997 and during the previous autumn (1996) when turbines were erected and some were working.

Scavenging Rate Determination. Two tests of scavenging were conducted. Scavenging was minimal as indicated by the small numbers of birds that disappeared from where they had been placed. In the first and shorter of the two, short-term disappearance was observed. Of twenty birds placed beneath turbines on June $30,15 \%(\mathrm{~N}=3)$ had disappeared by July 2 . These birds were checked again on September 2 at which time only 4 (20\% of original birds) were located. Those that were relocated included Blue Jay, Slate-colored Junco, Gray Catbird, and a Yellowrumped Warbler. They were all decomposed and were not easily found as feathers had matted down and lost all color as a result of photo-oxidation and perhaps washing by rain with low $\mathrm{pH}$. This shows that some birds disappear quickly, but scavenging is not the same at all sites nor in all seasons. Scavenging may have been even less than $80 \%$ during the 2 month period because some carcasses may have simply been overlooked as a result of decomposition and growth of grass and shrubs which act to make carcasses less visible.

For birds placed out on September 2, 20\% disappeared during the first week and another 15\% disappeared about a week later. At the end of a month (about 5 weeks/scavenging surveys), 65\% of the birds remained. There was no scavenging after the second week. Again, scavenging occurred, but it was not thorough.

Carcass Detectability - Observer Variability/Efficiency/Inter-observer Reliability. The two observers found 7 of 10 carcasses and 4 of 10 carcasses during their searches. Thus, the detectability rate varied greatly between $70 \%$ and $40 \%$, with an average of about $55 \%$. This means that about one-half of all carcasses would be found by these observers. It should be remembered that this figure will vary greatly depending on many factors.

\section{Discussion and Conclusions}

The most important finding in this study is that not one dead bird was found beneath the turbines at Searsburg in 1997. The fact that no birds were found dead in the area around the turbine towers may not mean that the turbines cause no fatalities, although it strongly suggests they are not killing large numbers of birds. Because this is the first study of fatalities at an operating wind power facility in the eastern United States, the results should not be generalized to all situations in this area.

The absence of carcasses beneath the turbines can be explained by several alternative hypotheses. First, scavenging of carcasses is common at sites where large numbers of birds collide with TV/radio and other types of towers. This is unlikely at Searsburg Wind Power Facility because empirically determined scavenging rates were low.

The fact that some carcasses placed out in June were present in September and that only 35\% of carcasses placed out in September disappeared within a month demonstrates that scavenging in the area is not a major methodological issue for determining whether birds are being killed by turbines. If scavenging had been much greater, perhaps in the range of $80-90 \%$ in a week, as 
occurs around some TV/radio towers, then it would have been difficult to locate carcasses. Scavengers are rather rare on the Searsburg wind power facility. Among avian scavengers in the area are Turkey Vultures, Common Ravens, American Crows, and Blue Jays. Of these Turkey Vultures were never seen soaring around the turbines, Common Ravens are present mostly in autumn and winter - infrequently on the hilltops, American Crows rarely frequent the site, and perhaps Blue Jays are not capable of moving carrion the size of small birds. Potential mammal scavengers include raccoon, skunk, coyote, bear, fox, weasel, dogs, and cats. Of these, only bears, coyotes, dogs, and are in the area. Coyotes are undoubtedly the best scavengers of these species and one was seen on site during breeding bird surveys. Also, pet dogs were on site with workers. None posed a serious problem to finding carcasses.

Also, the fact that detectability of carcasses ranged between $40 \%$ and $70 \%$ for the two observers strongly suggests that turbine-kills would be found if they occurred in appreciable numbers. With an average detectability of 55\% and scavenging rate of about $20 \%$ (a very generous rate given what was found) per week, only 2 or 3 birds would have to be killed for one to be found by an observer doing systematic searches. Thus, it is likely that few birds were killed and fell beneath the turbines in the areas searched.

Another hypothesis that may be ruled out is that the searches were not conducted at the time of year when fatalities occur. The seasonal occurrence of the carcass searches, however, was ideal for detecting dead birds. That time period included much of the nesting season and a majority of the autumn migration season for songbirds and hawks. Thus, the timing of the searches coincided with peak activity periods for songbirds and hawks, both migrating and breeding. After October very few hawks or songbirds remain in the northern forests and most birds have already finished migrating from or through this area.

It is possible that birds cannot be found when they fall beneath the turbines because they are cryptically colored in some cases. This hypothesis can also be ruled out because searchers were able to readily locate small, cryptically colored birds during several tests.

However, one hypothesis that cannot be discounted is that carcasses land in the forests beyond the cleared areas. These areas were outside of the area usually searched in studies of avian fatalities. This factor is an important consideration for future studies involving fatality searches in or adjacent to forests. Gauthreaux (1995) has astutely outlined the need for standardized techniques and design for avian research at proposed and operating wind power facilities. Such techniques, now being proposed by Anderson et al. (1998, in prep.), should be broad enough to be adapted to varying topography and habitat. Searching for carcasses of songbirds, or even small raptors the size of Sharp-shinned Hawks and Broad-winged Hawks, in forested areas is a difficult task. Because most songbirds are small and because the forest vegetation is so thick, finding a bird carcass after it has fallen into the forest is a daunting task. In some cases carcasses may not even reach the ground, but may be suspended in thick vegetation such as the small stands of spruce that are on the site.

The present study had the advantage of being able to search for birds before shrubs and small trees, and even grasses, began to make searching problematic. This is similar to studies of avian 
fatalities in the western United States where turbines are situated in grasslands or semi-desert (see Colson \& Associates 1995, Orloff and Flannery 1996). Much or most of the area cleared for the turbines at Searsburg that included the search area was lacking in vegetation during the searches. This will not be the case in one to two years. It is suggested that new methods for searching be developed. Such new techniques will need to be explored to either verify the findings presented here or to investigate new wind-power facilities as they come on-line in the eastern United States.

It should be noted that there is one additional factor that explains the lack of fatalities at Searsburg. Unlike the Altamont Wind Resource Area near Livermore, California, Searsburg does not host a large population of raptors. It also is not a site where migration activity is exceptional. In fact, studies have demonstrated that the area is not frequented by many raptors or songbirds during migration (see Chapters 5 and 6 ). The area also does not host many nesting raptors according to Capen and Coker (1994) and my own observations during two years of conducting songbird surveys in the area. In these two years no raptors were seen within several hundred yards of the wind turbines. Thus, it is likely that the reason dead birds were not found beneath the turbines is that they are not killed by the turbines at Searsburg or that they are killed in such low numbers as to be virtually impossible to detect. 


\section{Table 7.1. Dates of Searches for Dead Birds Under Turbines in 1997.}

Each search entailed 30 minutes of searching under each of four towers for a total of 2 hours of searches per day, not including time needed to move between turbines.

Date $\quad$ Turbine Numbers $\quad$ Number of Dead Birds

1. June 3

$11,10,9,8$

0

2. June 4

$11,10,9,8$

0

3. June 30

$7,6,5,4$

$1,2,3,4$

4. June 30

$7,6,5,4$

5. July 1

$1,2,3,4$

7. July $2 *$

$1,2,3,4$

$11,10,9,8$

$1,2,3,4$

$11,10,9,8$

$11,10,9,8$

0

0

0

0

8. September 2

9. September 2*

10. September 9*

11. September $17 *$

$7,6,5,4$

$7,6,5,4$

4, 3, 2, 1

$7,6,5,4$

$11,10,9,8$

0

12. September 17

13. September 27

14. September 27*

15. October 2

16. October $2 *$

17. October 7

18. October 10

$11,10,9,8$

0

19. October 11

$3,2,1$

$7,6,5,4$

$3,2,1$

0

0

20. October 15

$11,10,9,8$

0

0

21. October 18

0

0

0

0

0

0

0

0

0

0

Total Search Periods $=21$

Total

0

Search Days $=15$

Individual Turbines Searched $=82$

* Indicates these searches also involved checking for carcasses left for scavenging studies. 


\section{Table 7.2. Inventory of Birds Used and Locations for Scavenging Study and Examination of Inter-Observer}

Efficiency/Reliability.

June 30, 1997

$\underline{\text { Turbine \#1 }}$

Yellow-rumped Warbler* Yellow-billed Cuckoo

House Finch

American Robin*

Cedar Waxwing*

September 9, 1997

$\underline{\text { Turbine \#8 }}$

Ovenbird*

Baltimore Oriole*

Yellow Warbler

Cedar Waxwing*

Yellow Warbler
Turbine \#2

Cedar Waxwing*

Golden-crowned Kinglet*

American Robin*

White-throated Sparrow*

American Woodcock* $\underline{\text { Turbine \#3 }}$

Gray Catbird*

Slate-colored Junco*

Yellow-rumped Warbler*

Blue Jay*

Chipping Sparrow*
Turbine \#4

Comon Yellowthroat

White-throated Sparrow*

Northern Cardinal

White-throated Sparrow*

Slate-colored Junco*

* Indicates species known to breed on or adjacent to the site as determined by studies by this author (see Chapter 4). 


\section{Chapter 8. General Conclusions}

The impact of wind turbines on birds can be categorized in various ways. Impacts can be realized as fatalities, changes in behavior, and changes in ecology of the site that result in changes in behavior or reproductive success, or population stability. The present study is the first in the eastern United States to examine these factors by thorough behavioral and ecological studies prior to and after the erection of a commercial scale wind power facility, as well as searches for carcasses under and near the turbines.

Conclusions regarding these studies and the overall impact of the turbines on birds are treated as four discrete units: night migrating songbirds, diurnal hawk migration, carcass searches, and breeding birds. Overall, it appeared that impacts were minor. Those that were found are not likely to significant adverse effects on populations of any species on a regional scale.

The fact that fewer hawks and songbirds were observed flying over the site after the turbines were erected suggests that the turbines may have changed the migratory behavior of a number of individuals. The change in behavior may be simple avoidance behavior in which the birds deviated their course to provide a margin of safety when they encountered these new objects on the landscape. Such a deviation in their migratory course is unlikely to result in a significant increase in the amount of energy required, navigational confusion, or any other negative effect. Thus, migratory behavior, though possibly changed as a result of turbine erection, was not affected in a negative fashion.

One caveat regarding the migration studies is that they represent only one spring and autumn migration season before construction on the site and one spring and autumn migration season after construction of the turbines. The amount of variability in numbers of migrants aloft, even with 14 days of observations in each season for songbirds and 20 days of observations for hawks, can be great. It is likely that the number of days of observations was sufficient to cover the a large portion of the migration season at the site during the study period and that the data are representative of the migration there.

That no carcasses were found on site during the carcass searches, by maintenance workers, or during casual travels through the site suggests that large numbers of birds are not colliding with the turbines and it is likely that only a few, if any birds have been impacted in this fashion. This suggestion is reinforced by the fact that scavenging was minimal, which would mean that carcasses were not being systematically removed from the site. Small numbers of birds could collide with the turbines and not be found, especially if the numbers were very small or if the carcasses fell in the forest. If the latter were the case, at least one dead bird would undoubtedly have been located during the intensive carcass searches. If very small numbers of birds (perhaps fewer than 3-4 birds) were colliding with the turbines, this probably would not impact populations of migrants or locally breeding birds. The fact that no endangered or threatened species were found breeding on the site also reinforces this contention.

The possible impact to birds that emerged from the studies was a reduction in the numbers of some breeding songbirds, especially those that are dependent on large, forested tracts. These 
species are primarily Neotropical migrants that have recently been shown to be declining in some portions of the United States and Canada. Other species of songbirds were not impacted and there were no hawks breeding on site. The presence of Bicknell's Thrush on and near the site is problematic. Although the site is elevationally below the level at which this bird breeds, its presence should be considered in future developments of this sort in Vermont and elsewhere.

Thus, the only empirical evidence from this study that demonstrates a potential adverse impact on birds is that of habitat alteration as a result of clearing small "pockets" within the forest for turbine placement and the construction of roads to the turbines. More than a dozen acres of habitat were removed or modified for the turbines and this modification served to fragment a previously unfragmented (except during logging) forested area. The roads and areas beneath the turbines that were cleared resulted in the reduction of territorial activity and presence of several species in the immediate area surrounding the turbines. The birds that were impacted are thought to be sensitive to fragmentation and dependent on forest interior habitats. Concordant with the reduction of these species, there was an increase of several edge species that normally do not reside in the forest interior.

It is not known if these birds simply moved farther into the forest or did not breed after the forest was cut and turbines erected. However, the numbers of these species and individuals involved, when considered from the perspective of several square miles of surrounding forest, is very small and, perhaps, not significant when considered from a population perspective. It is possible that as the roadside edges and cleared areas surrounding the turbine towers revert to forest and brush, the forest interior birds may recolonize the cleared areas. That the cleared areas are being allowed to revegetate as part of the management plan is important because it the management plan specifically recognized the needs of interior birds and attempted to reverse or minimize the negative impacts of forest clearing and fragmentation. By 1998 the clearings were already covered with grasses (unmowed) and small trees (mostly black cherry and birch), some of which were nearly a meter in height.

The potential for negative impacts resulting from habitat modification and presence of turbines should not be taken lightly as forest fragmentation is an important and timely conservation issue among wildlife managers and conservation organizations. The fact that many forest interior species are declining is significant, especially with wind power development being proposed for forested areas of the northeast. The question of interest to conservationists and agency regulators is whether these species can coexist with turbines. Whereas some species at Searsburg seemed to "adapt" readily to the turbines, others may not. Studies following construction that track populations over several years as the forest regenerates should answer this question.

In closing, it is important to note that not all sites or all species are equal. Other sites at similar elevations and with similar forests may host different species that may not respond as the species at Searsburg responded to wind power development. Lower and higher elevation forests will have different species composition and different migration regimes. High elevation sites may be more sensitive, thus warranting intensive studies. 


\section{Chapter 9. Literature Cited}

Able, K. P. 1966. Television tower mortality near Louisville. Kentucky Warbler 42:27-28.

Able, K. P. 1970. A radar study of the altitude of nocturnal passerine migration. Bird-Banding 41:282-290.

Able, K. P. 1973. The role of weather variables and flight direction in determining the magnitude of nocturnal bird migration. Ecology 54:1031-1041.

Able, K. P., and S. A. Gauthreaux. 1975. Quantification of nocturnal passerine migration with a portable ceilometer. Condor 77:92-96

Able, K. P., and B. R. Noon. 1976. Avian community structure along elevational gradients in the northeastern United States. Oecologia 26:275-294

Aldrich, J. W., R. R. Graber, D. A. Munroe, G. J. Wallace, G. C. West, and V. H. Cahalane. 1966. Mortality at ceilometers and towers. Auk 83:465-467.

Anderson, R.L., M. Morrison, K. Sinclair, and D. Strickland. In prep. Studying wind energy/bird interactions; a guidance document. Metrics and methods for determining or monitoring potential impacts on birds at existing and proposed wind energy sites. Draft 5. Prepared for the National Wind Coordinating Committee's Avian Subcommittee. April 1999.

Anderson, R.L., in press. Avian monitoring and risk assessment at Tehachapi and San Gorgonio, WRAs. Proc. National Avian Wind Power Interaction workshop III, May 1998, San Diego, CA. National Winc Coordinating Committee/RESOLVE, Inc.

Anonymous. 1954. Disaster in migration. Chat 18:104-105.

Aronoff, A. 1949. The September migration tragedy. Linnaean Newsletter 3:1-2.

Avery, M., and T Clement. 1972. Bird mortality at four towers in eastern North Dakota: Fall 1972. Prairie Naturalist 4:87-95.

Avery, M., P. F. Springer, and J. F. Cassel. 1976. Effects of a tall tower on nocturnal migrationa portable ceilometer study. Auk 93:281-291.

Avery, M., P. F. Springer, and J. F. Cassel. 1977. Weather influences on nocturnal bird mortality at a North Dakota tower. Wilson Bulletin 89:291-299.

Avery, M., P. F. Springer, and N. S. Dailey. 1980. Avian mortality at man-made structures: An annotated bibliography (revised). U. S. Fish and Wildlife Service, Biological Services Program, National Power Plant Team, FWS/OBS-80/54. 152 pp. 
Bagg, A. M., and R. P. Emery. 1964. The fall migration: northeastern maritime region. Audubon Field Notes 18:7-17.

Baird, J. 1962. The changing seasons: a summary of the fall migration. Audubon Field Notes 16:4-6.

Baird, J., R. I. Emery, and R. Emery. 1959. Fall migration: northeastern maritime region. Audubon Field Notes 13:11-13.

Ball, R. E. 1973. Bird mortality at towers in Marysville, Missouri: Fall 1972. Transactions, Missouri Academy of Science 7-8:294.

Banks, R. C. 1979. Human related mortality of birds in the United States. U. S. Fish and Wildlife Service Special Scientific Report - Wildlife. No. 215:1-16

Benner, J. H. B., J. C. Berkhuizen, R. J. de Graaff, and A. D. Postma. 1993. Impact of wind turbines on birdlife. Final report no. 9247. Consultants on Energy and the Environment, Rotterdam, Netherlands.

Benning, W. E. 1978. Region 3: Finger Lakes. Kingbird 28:42-44.

Bierly, M. L. 1973. 1971 fall television tower casualties in Nashville. Migrant 44:5-6.

Bingman, V. P., K. P. Able, and P. Kerlinger. 1982. Wind drift, compensation, and the use of landmarks by nocturnal bird migrants. Animal Behaviour 30:49-53.

Brewer, R., and J. A. Ellis. 1958. An analysis of migrating birds killed at a television tower in east-central Illinois, September 1955-May 1957. Auk 75:400-414.

Caldwell, L. D., and N. L. Cuthbert. 1963. Bird mortality at television towers near Cadillac, Michigan. Jack-Pine Warbler 41:80-89.

California Energy Commission. 1995. Avian collision and electrocution: an annotated bibliography. California Energy Commission. pp. 114.

Capen, D. E., and D. R. Coker. 1994. Avian studies - proposed Green Mountain Power wind turbine project - Searsburg and Readsboro, Vermont, Summer 1994. Report to Green Mountain Power.

Carter, J. H. III, and J. F. Parnell. 1976. TV tower kills in eastern North Carolina. Chat 40:1-9.

Chamberlain, B. R. 1957. Fall migration: southern Atlantic coast region. Audubon Field Notes 11:15-18. 
Cochran, W. W. and R. R. Graber. 1958. Attraction of nocturnal migrants by lights on a television tower. Wilson Bulletin 70:378-380.

Colson \& Associates. 1995. Avian interactions with wind energy facilities: a summary. Report for the American Wind Energy Association.

Cooper, B. A., C. B. Johnson, and E. F. Neuhauser. 1995. Proceedings of the American Wind Energy Association Conference, March 26-30, 1995, American Wind Energy Association, Washington, DC. pp. 607-611.

Crockford, N. J. 1992. A review of the possible impacts of wind farms on birds and other wildlife. Joint Nature Conservation Committee, JNCC Report No. 27, Peterborough, U. K.

Eaton, S. W. 1967. Recent tower kills in upstate New York. Kingbird 17:142-147.

Elkins, N. 1988. Weather and bird behavior. 2nd edition. T. \& A. D. Poyser, Calton, Staffordshire, England. 239 pp.

Evans Ogden, L. J. 1996. The hazards of lighted structures and windows to migrating birds. Report from the World Wildlife Fund Canada, Toronto, Canada (unfinished report).

Feehan, J. 1963. Destruction of birdlife in Minnesota - Sept. 1963. Birds killed at the Ostrander television tower. Flicker 35:111-112.

Gauthreaux, S. A., Jr. 1969. A portable ceilometer technique for studying low-level nocturnal migration. Bird-Banding 40:309-320.

Gauthreaux, S. A., Jr. 1970. Weather radar quantification of bird migration. BioScience 20:1720 .

Gauthreaux, S. A., Jr. 1971. A radar and direct visual study of passerine spring migration in southern Louisiana. Auk 88:343-365.

Gauthreaux, S. A., Jr. 1973. Quantification of bird echoes on airport surveillance radars. Proceedings of a Conference on Transparent Aircraft Enclosures, Las Vegas, Nevada, February 1973.

Gauthreaux, S. A., Jr. 1985. Radar, electro-optical, and visual methods of studying bird flight near transmission lines. Clemson University, Clemson, SC. Electric Power Research Institute, Palo Alto, CA. EPRI EA-4120. 76 pp.

Gauthreaux, S. A. Jr. 1995. Designs for avian-wind power research: Standardized assessment and monitoring protocols. Proc. National Avian-Wind Power Planning Meeting, Denver, CO, July 1994. pp. 53-59. 
Goodwin, C. E. 1975. The winter season: Ontario region. American Birds 29:48-57.

Goodwin, C. E., and R. C. Rosche. 1971. The fall migration: Ontario. Amer. Birds 25:49-54.

Green, J. C. 1963. Destruction of birdlife in Minnesota - Sept. 1963. Notes on kills at Duluth on September 18/19. Flicker 35:112-113.

Green, J. C. 1964. Fall migration: western Great Lakes region. Audubon Field Notes 18:33-34; $39-42$.

Hall, G. A. 1966. Fall migration: Appalachian region. Audubon Field Notes 20:41-45.

Hall, G. A. 1968. Fall migration: Appalachian region. Audubon Field Notes 22:37-40.

Hall, G. A. 1975. The fall migration: Appalachian region. American Birds 29.

Hall, G. A. 1976. The fall migration: Appalachian region. American Birds 30:67-71.

Hall, G. A. 1977. The autumn migration: Appalachian region. American Birds 31:176-179.

Hebrard, J. J. 1971. The nightly initiation of passerine migration in spring: A direct visual study. Ibis 113:8-18.

Herbert, A. D. 1970. Spatial disorientation in birds. Wilson Bulletin 82:400-419.

Hoskin, J. 1975. Casualties at the CKVR-TV tower, Barrie. Nature Canada 4:39-40.

Howell, J. A., and J. E. DiDonato. 1991. Assessment of avian use and mortality related to wind turbine operations, Altamont Pass, Alameda and Contra Costa Counties, California, September 1988 through August 1989. Final Report for U. S. Windpower, Inc. (Kenetech Windpower), San Francisco, CA.

Howell, J. A., and J. Noone. 1992. Examination of avian use and mortality at a U. S.

Windpower energy development site, Montezuma Hills, Solano County, California. Final report prepared for Solano County Dept. of Environmental Management, Fairfield, CA.

Howell, J. A., J. Noone, and C. Wardner. 1991. Visual experiment to reduce avian mortality related to wind turbine operations, Altamont Pass, Alameda and Contra Costa counties, California, April 1990 through March 1991. Final report prepared for U. S. Windpower, Inc. (Kenetech Windpower), San Francisco, CA.

Jacobs, M. B. 1994. Avian mortality and wind power in the northeast. Paper presented to the Windpower '94 Conference, Minneapolis, MN, Massachusetts Department of Public Utilities, Boston, MA. 
Jaroslow, B. 1979. A review of factors involved in bird-tower kills, and mitigative procedures. In The mitigation symposium: a national workshop on mitigation losses of fish and wildlife habitats. G. A. Swanson, ed. U. S. Forest Service Gen. Tech. Rept. RM-65. Pp. 469-473

Johnston, D. 1955. Mass bird mortality in Georgia, October 1954. Oriole 20:17-26.

Kale, H. 1971. The spring migration: Florida region. American Birds 25:723-725, 730-735.

Kale, H., M. H. Hundley, and J. A. Tucker. 1969. Tower-killed specimens and observations of migrant birds from Grand Bahama Island. Wilson Bulletin 81:258-263.

Kemper, C. A. 1958. Destruction at a TV tower. Passenger Pigeon 20:3-9.

Kemper, C. A. 1964. A tower for TV: 30,000 dead birds. Audubon 66(1):86-90.

Kerlinger, P. 1989. Flight strategies of migrating hawks. Univ. of Chicago Press, Chicago, IL.

Kerlinger, P. 1995a. Report prepared for Green Mountain Power Corporation and Vermont Environmental Research Associates.

Kerlinger, P. 1995b. Potential impacts to birds of a proposed wind turbine development on Nantucket Island, MA. Report prepared for the Conservation Law Foundation, Boston, MA.

Kerlinger, P. 1995c. How birds migrate. Stackpole Books, Mechanicsburg, PA.

Kerlinger, P., and F. R. Moore. 1989. Atmospheric structure and avian migration. Current Ornithology 6:109-142, ed. D. M. Power, Plenum, NY.

Kerlinger, P., and R. Curry. 1997. Analysis of Golden Eagle and Red-tailed Hawk fatalities on Altamont Ownership Consortium property within the Altamont Wind Resource Area (AWRA), October 1997. Report Prepared for Altamont Avian Plan, Altamont Ownership Consortium.

Kerlinger, P., and R. Curry. 1998. A comparison of a company sponsored Wildlife Response and Reporting System (WRRS) to intensive carcass search methods at wind turbines in the Altamont Pass, California: Golden Eagles and Red-tailed Hawks. Prepared for Altamont Infrastructure Corporation and Green Ridge Power, L.L.C.

Klem, D., Jr. 1989. Bird-window collisions. Wilson Bulletin 101:606-620.

Klem, D., Jr. 1990. Collisions between birds and windows: mortality and prevention. Journal of Field Ornithology 61:120-128. 
Klem, D., Jr. 1991. Glass and bird kills: an overview and suggested planning and design methods of preventing a fatal hazard. pp. 99-103. In Wildlife and conservation in metropolitan environments. L. W. Adams and D. L. Leedy, eds., National Institute for Urban Wildlife, Columbia, MD.

Laughlin, S. B., and D. P. Kibbe. 1985. The atlas of breeding birds of Vermont. University Press of New England (Vermont Institute of Natural Science), Hanover, NH.

Lupient, M. 1961. Fall migration: western Great Lakes region. Audubon Field Notes 15:42-44.

Maher, D. S., A. G. Spratt, and D. K. Voigts. 1983. Bird casualties at a central Florida power plant. Florida Field Naturalist 11:45-68.

Manuwal, D. D. 1963. TV transmitter kill in South Bend, Indiana, fall 1962. Indiana Audubon Quarterly 41:49-53.

Martin, N. 1993. Hawk migration at Searsburg, Vermont - 20 September to 28 October 1993. Report prepared for Green Mountain Power Corporation.

Martin, N. 1994. Hawk migration at Searsburg, Vermont - 1 to 20 September 1994. Report prepared for Green Mountain Power.

Mayfield, H. 1967. Shed few tears. Audubon 69(3):61-65.

McCrary, M. D., R. L. McKernan, R. E. Landry, W. D. Wagner, and R. W. Schreiber. 1983. Nocturnal avian migration assessment of the San Gorgonio wind resource study area, spring 1982. Report to Southern California Edison Company, Research and Development, Rosemead, CA. Prepared through the Los Angeles County Natural History Museum Foundation, Ornithology, LA. pp. 121.

Newman, R. J. 1957. The changing seasons. Audubon Field Notes 11:4-6.

Newman, R. J. 1958. The changing seasons. Audubon Field Notes 12:4-9.

Nisbet, I. C. T. 1963. Measurements with radar of the height of nocturnal migration over Cape Cod, Massachusetts. Bird-Banding 34:57-67

Noon, B. R. 1981. The distribution of an avian guild along a temperate elevational gradient: The importance and expression of competition. Ecological Monographs 51(1):105-124.

Northrop, Devine, and Tarbell, Inc. 1995a. New England wind energy station: Spring 1994 nocturnal songbird migration study report, January 1995. Report to Kenetech Windpower, Portland, ME. pp. 32. 
Northrop, Devine, and Tarbell, Inc. 1995b. New England wind energy station: Fall 1994 nocturnal songbird migration study report, August 1994. Report to Kenetech Windpower, Portland, ME. pp. $39+14$ figures.

Northrop, Devine, and Tarbell, Inc. 1995c. New England wind energy station: Autumn 1994 raptor migration survey summary report, January 1995. Report to Kenetech Windpower, Portland, ME. pp. $23+$ appendices.

Northrop, Devine, and Tarbell, Inc. 1995d. New England wind energy station: Spring 1994 nocturnal songbird migration study report, August 1995. Report to Kenetech Windpower, Portland, ME. pp. 35.

Norwood, J. R. 1960. TV tower casualties at a Charlotte station. Chat 24:103-104.

Orloff, S., and A. Flannery. 1992. Wind turbine effects on avian activity, habitat use, and mortality in Altamont Pass and Solano County wind resource areas. 1989-1991. California Energy Commission, CA.

Orloff, S., and A. Flannery. 1996. A continued examination of avian mortality in the Altamont Pass wind resource area. California Energy Commission, CA.

Parmalee, P. W., and B. G. Parmalee. 1959. Mortality of birds at a television tower in central Illinois. Bulletin of the Illinois Audubon Society 111:1-4.

Parmalee, P. W., and M. D. Thompson. 1963. A second kill of birds at a television tower in Illinois. Bulletin of the Illinois Audubon Society 128:13-15.

Petersen, P. C. 1959. TV tower mortality in western Illinois. Bulletin of the Illinois Audubon Society 112:14-15.

Petersen, P. C. 1968. Fall migration: middlewestern prairie region. Audubon Field Notes 22:48-50.

Potter, J. K., and J. J. Murray. 1949. Fall migration: middle Atlantic coast region. Audubon Field Notes 3:8-10.

Richardson, W. J. 1971. Spring migration and weather in eastern Canada: a radar study. American Birds 25:684-690.

Robbins, S. D. 1969. Fall migration: western Great Lakes region. Audubon Field Notes 23:5556,64 .

Rosche, R. C. 1970. The fall migration: western New York and northwestern Pennsylvania. Audubon Field Notes 24:43-47. 
Rosche, R. C. 1971. The fall migration: western New York and northwestern Pennsylvania. American Birds 25:54-57.

Rosche, R. C. 1972. The fall migration: western New York and northwestern Pennsylvania. American Birds 26:60-62.

Scott, F. R., and D. A. Cutler. 1965. Fall migration: middle Atlantic coast region. Audubon Field Notes 19:21-24.

Scott, F. R., and D. A. Cutler. 1971. Fall migration: middle Atlantic coast region. American Birds 25:36-40.

Scott, F. R., and D. A. Cutler. 1972. Fall migration: middle Atlantic coast region. American Birds 26:41-45.

Seets, J. W., and H. D. Bohlen. 1977. Comparative mortality of birds at television towers in central Illinois. Wilson Bulletin 89:422-433.

Stoddard, H. L., and R. A. Norris. 1967. Bird casualties at a Leon County Florida TV tower: an eleven-year study. Tall Timbers Research Station Bulletin No. 8. Tallahassee, Florida. pp. 104.

Strand, F. 1962. Birds killed at the KROC-TV tower, Ostrander, Minnesota. Flicker 34:7-9.

Strickland, D. in press. Avian use, flight behavior, and mortality on the Buffalo Ridge, Minnesota, Wind Resource Area. Proc. National Avian Wind Power Interaction workshop III, May 1998, San Diego, CA. National Winc Coordinating Committee/RESOLVE, Inc.

Tanner, J. T. 1954. Knoxville. Migrant 25:64-65.

Trott, J. 1957. TV tower fatalities at Chapel Hill. Chat 2:28.

Weir, R. D. 1974. Bird kills at the Lennox generating plant, spring and autumn 1974. Blue Bill 21:61-62.

Weir, R. D. 1976. Annotated bibliography of bird kills at man-made obstacles: a review of the state of the art and solutions. Canadian Wildlife Services, Ontario Region, Ottawa. pp. 85.

Weir, R. D. 1977. Bird kills at the Lennox generating plant, spring and autumn 1977. Blue Bill 24:40-42.

Welles, M. 1978. TV tower kill at Elmira. Kingbird 28:159-161.

Whelan, P. 1976. The bird killers. Ontario Naturalist 16:14-16.

Winkelman, J. E. 1994. Bird/wind turbine investigations in Europe. Presented at the National 
Wind Avian Windpower Planning Meeting at Golden, Colorado, July 20, 1994

Winkelman, J. E. 1995. Bird/wind turbine investigations in Europe. Proc. National avian-wind power planning meeting, Denver, CO, July 1994. pp. 43-47.

Zimmerman, D. A. 1975. The changing seasons. American birds 29:23-28. 


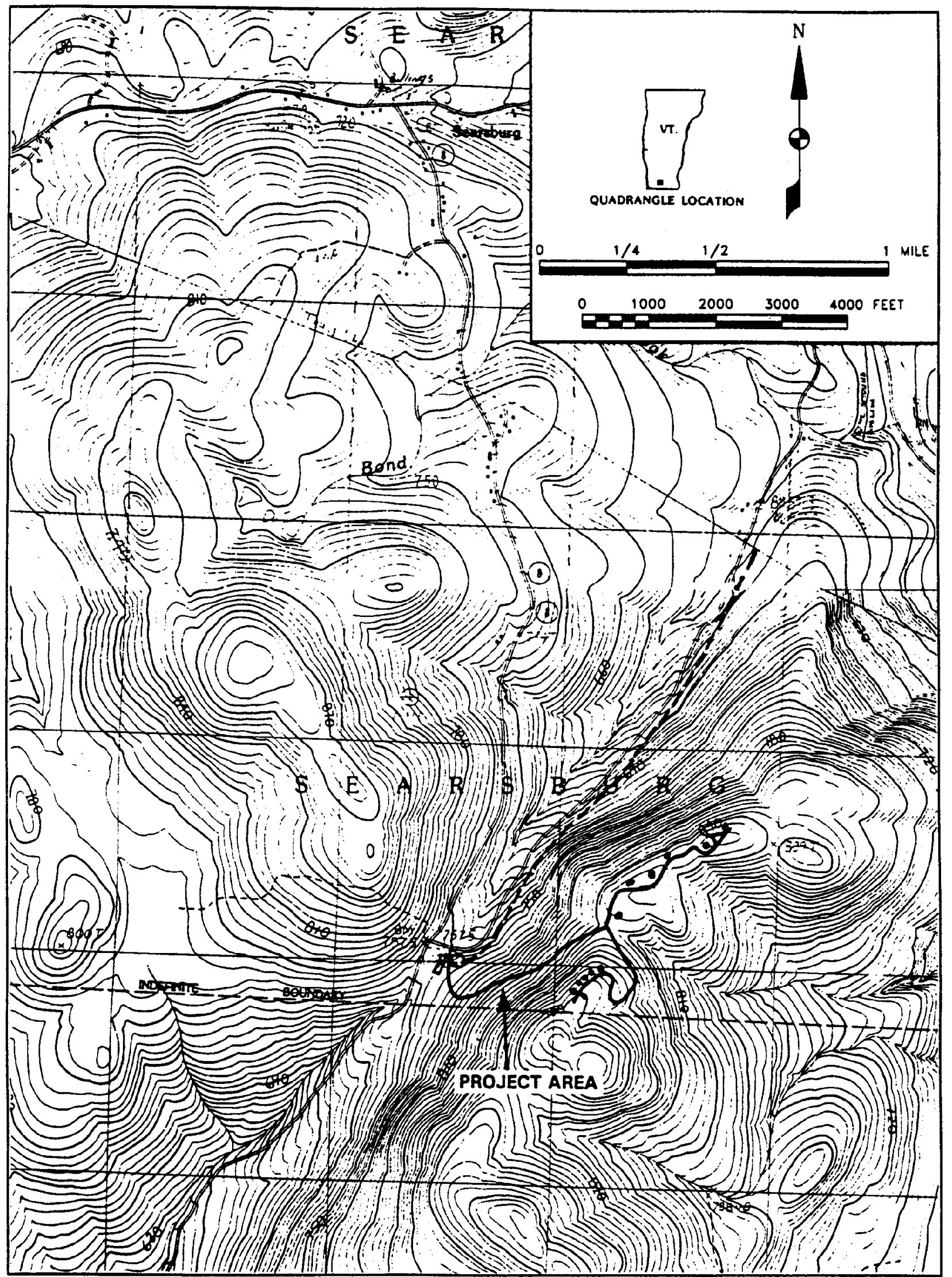

FIGURE 1: Location of Project Area

SOURCE: USGS 7.5 Minute Quadrangles, Mount Snow, VT 1986 and Reedsboro, vT 1987

Figure 1. Map of the Green Mountain Power Searsburg, Vermont windpower site showing location of 11 Z-40 turbines. Dots along road indicate location of individual turbines at tops of hills. Constructed road originates at bottom of hill to west of turbines and runs up hill, splitting to north and south strings of turbines. Total cleared area encompassed by road and turbines was about 12 acres ( 5 hectares). Cleared areas around turbines and along roadsides are being allowed to succeed to natural vegetation state, with clearing of trees done as needed for maintenance. Footprint should be reduced to about 8 acres (about 3 hectares.) 


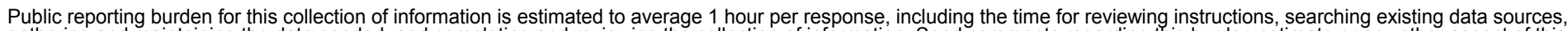

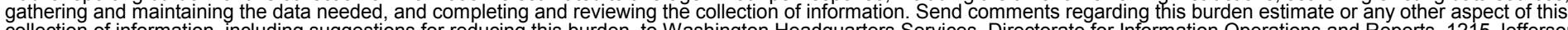
gton Headquarters Services, Directorate for Ination Operations and Reports, 1215 Jefferson Davis Highway, Suite 1204, Arlington, VA 22202-4302, and to the Office of Management and Budget, Paperwork Reduction Project (0704-0188), Washington, DC 20503.
1. AGENCY USE ONLY (Leave blank)
2. REPORT DATE
March 2002
3. REPORT TYPE AND DATES COVERED Subcontract Report

4. TITLE AND SUBTITLE

An Assessment of the Impacts of Green Mountain Power Corporation's Wind Power

Facility on Breeding and Migrating Birds in Searsburg, Vermont

Period of Performance: July 1996-July 1998
5. FUNDING NUMBERS

WE001910

ZAT-6-15179

6. $\operatorname{AUTHOR}(\mathrm{S})$

Paul Kerlinger, Ph.D.

7. PERFORMING ORGANIZATION NAME(S) AND ADDRESS(ES)

Curry \& Kerlinger, L.L.C.

8. PERFORMING ORGANIZATION REPORT NUMBER

Cape May Point, NJ 08212

9. SPONSORING/MONITORING AGENCY NAME(S) AND ADDRESS(ES)

National Renewable Energy Laboratory

1617 Cole Blvd.

Golden, CO 80401-3393

10. SPONSORING/MONITORING AGENCY REPORT NUMBER

NREL/SR-500-28591

11. SUPPLEMENTARY NOTES

NREL Technical Monitor: Karin Sinclair

12a. DISTRIBUTION/AVAILABILITY STATEMENT

National Technical Information Service

U.S. Department of Commerce

5285 Port Royal Road

Springfield, VA 22161

13. ABSTRACT (Maximum 200 words)

A 6-megawatt, 11 turbine wind power development was constructed by Green Mountain Power Corporation in Searsburg, southern Vermont, in 1996. To determine whether birds were impacted, a series of modified BA (Before, After) studies was conducted before construction (1993-1996), during (1996), and after (1997) construction on the project site. The studies were designed to monitor changes in breeding bird community (species composition and abundance) on the site, examine the behavior and numbers of songbirds migrating at night over the site and hawks migrating over the site in daylight, and search for carcasses of birds that might have collided with the turbines.

Overall, results of the studies suggest that the Searsburg, Vermont wind power facility does not pose a major threat to avian populations that breed on the site or migrate through the site. However, fewer interior forest breeding songbirds were heard singing in the area immediately surrounding the turbines. This effect may be transitory in that these birds may habituate and recolonize as the sites are partially reforested. However, until this is demonstrated, this disturbance should be recognized as a potential impact of this type of development, especially in northeastern forests.

\begin{tabular}{|c|c|c|c|}
\hline \multirow{2}{*}{\multicolumn{3}{|c|}{$\begin{array}{l}\text { 14. SUBJECT TERMS } \\
\text { Wind turbine; bird migration; bird breeding; bird population }\end{array}$}} & 15. NUMBER OF PAGES \\
\hline & & & 16. PRICE CODE \\
\hline $\begin{array}{l}\text { 17. SECURITY CLASSIFICATION } \\
\text { OF REPORT } \\
\text { Unclassified }\end{array}$ & $\begin{array}{l}\text { 18. SECURITY CLASSIFICATION } \\
\text { OF THIS PAGE } \\
\text { Unclassified }\end{array}$ & $\begin{array}{l}\text { 19. SECURITY CLASSIFICATION } \\
\text { OF ABSTRACT } \\
\text { Unclassified }\end{array}$ & $\begin{array}{l}\text { 20. LIMITATION OF ABSTRACT } \\
\text { UL }\end{array}$ \\
\hline
\end{tabular}

